UMSIDA

Filda 5ka Wolandart, S.Str. M.Pd. ita Wolandiat, M.Pri.

\title{
ORGANISASI
}

UMSIDA Press

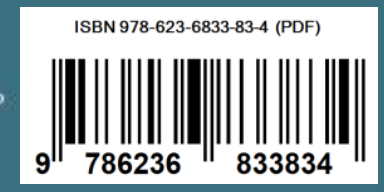

Universitas Mahamamadlyah Sidoarjo I1. Mojopahit 666 B Sidoarjo 9 786236 


\section{BUKU AJAR \\ ORGANISASI LABORATORIUM}

Oleh

Fitria Eka Wulandari, S.Si., M.Pd.

Ria Wulandari, M.Pd.

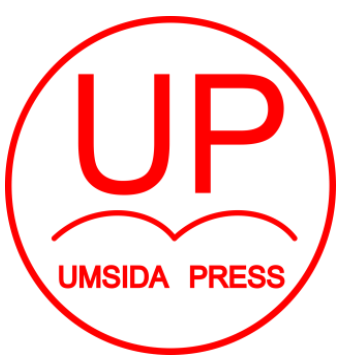




\section{BUKU AJAR}

\section{ORGANISASI LABORATORIUM}

\section{Penulis:}

Fitria Eka Wulandari, S.Si., M.Pd.

Ria Wulandari, M.Pd.

\section{ISBN :}

978-623-6833-83-4

\section{Editor:}

Dr. Septi Budi Sartika, M.Pd.

\section{Design Sampul dan Tata Letak:}

Mochammad Nashrullah, S.Pd.

Amy Yoga Prajati, S.Kom.

Penerbit:

UMSIDA Press

Anggota IKAPI No. 218/Anggota Luar Biasa/JTI/2019

Anggota APPTI No. 0020181092017

Redaksi

Universitas Muhammadiyah Sidoarjo

Jl. Mojopahit No 666B

Sidoarjo, Jawa Timur

Cetakan Pertama, September 2020

CHak Cipta dilindungi undang undang

Dilarang memperbanyak karya tulis ini dengan sengaja, tanpa ijin tertulis dari penerbit. 


\section{KATA PENGANTAR}

Puji syukur kami panjatkan kepa Allah SWT. Yang telah memberikan rahmad serta hidayahnya kepada kami sehingga kami sehingga kami dapat menyelesaikan Buku Ajar Matakuliah Asesmen Laboratorium tepat pada waktunya.

Tim penulis mengucapkan terimakasih yang sebanyak-banyaknya kepda pihak-pihak yang telah membantu terselesaikannya buku ajar ini.

Saran dan kritik yang membangun sangat diharapkan untuk dapat mewujudkan buku ajar yang lebih baik sesuai dengan capaian pembelajaran yang telah dijabarkan.

Penulis 


\section{DAFTAR ISI}

HALAMAN SAMPUL

KATA PENGANTAR

\section{DAFTAR ISI}

\section{BAB I PENDAHULUAN}
A. Sub Capaian Pembelajaran Mata Kuliah__1
B. Latar Belakang__1
C. Tujuan_4
D. Dasar Hukum_4
E. Keterkaitan kegiatan laboratorium dengan kurikulum 2013_5
F. Kegiatan Laboratorium dalam Pengembangan Penguatan Literasi Sains dan Pendidikan Karakter_ 7

\section{BAB II ESENSI LABORATORIUM DAN PERANNYA DALAM IPA}
A. Sub-Capaian Pembelajaran Mata Kuliah_11
B. Pengertian Laboratorium__11
C. Macam-macam laboratorium IPA_12

BAB III KOMPETENSI ILMUAN TERLATIH DI LABORATORIUM IPA
A. Sub-Capaian Pembelajaran Mata Kuliah 14
B. Keterampilan IImuan IPA_14
C. Penilaian keterampilan proses Sikap seorang ilmuan IPA_14
D. Membuat Laporan Praktikum

\section{BAB IV PERENCANAAN LABORATORIUM DAN PENGELOLAAN LABORATORIUM}
A. Perencanaan Laboratorium_24
B. Pengelolaan laboratorium _ 24 


\section{BAB V PENATAAN DAN PEMELIHARAN ALAT DAN BAHAN}

\section{LABORATORIUM}
A. Penataan Alat dan Bahan laboratorium_31
B. Pemeliharaan Alat dan Bahan Laboratorium 31

\section{BAB VI PENGADMINISTRASIAN LABORATORIUM}
A. Sub-Capaian Pembelajaran Mata Kuliah_ 40
B. Definisi Laboratorium IPA_40
C. Daftar administrasi laboratorium 42
D. Inventarisasi alat dan fasilitas laboratorium 45
E. Administrasi stok Laboratorium 47
F. Administrasi kegiatan di laboratorium_ 50
G. Administrasi peminjaman alat dan bahan_ 53
$\mathrm{H}$. Administrasi pengkodean Alat dan bahan_ 57

BAB VII PENGAMANAN, PERAWATAN, DAN PENGAWASAN
A. Jenis perawatan
58
B. Tenaga perawatan_ 58
C. Biaya perawatan 58
D. Bahan perawatan__64

BAB VIII Keselamatan kerja di laboratorium

A. Menjaga keselamamatan dilaboratorium_67 67

B. Kecelakaan yang mungkin terjadi dilaboratorium_ 71

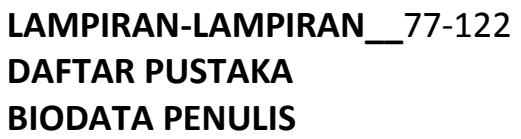


BATANG TUBUH \& CAPAIAN PEMBELAJARAN MATA KULIAH

\begin{tabular}{|c|c|}
\hline BAB & Sub-Capaian Pembelajaran Mata Kuliah \\
\hline BAB I PENDAHULUAN & $\begin{array}{l}\text { 1. Dapat menjelaskan Latar Belakang peranan } \\
\text { laboratorium dalam pembeljaran } \\
\text { 2. Dapat menjelaskan tujuan pembelajaran } \\
\text { laboratorium } \\
\text { 3. Dapat memahami dasar-dasar hukum } \\
\text { landasan pembelajaran laboratorium IPA } \\
\text { 4. Dapat mengaplikasikan Keterkaitan kegiatan } \\
\text { laboratorium dengan kurikulum } 2013 \\
\text { 5. Dapat melakukan Penguatan pendidikan } \\
\text { karakter dan literasi melalui kegiatan } \\
\text { laboratorium }\end{array}$ \\
\hline $\begin{array}{lr}\text { BAB III } & \text { ESENSI } \\
\text { LABORATORIUM } & \text { DAN } \\
\text { PERANNYA DALAM IPA }\end{array}$ & $\begin{array}{l}\text { 1. Dapat memahami Pengertian Laboratorium } \\
\text { IPA } \\
\text { 2. Dapat menjelaskan Macam-macam } \\
\text { laboratorium IPA } \\
\text { 3. Dapat memahami Peran Laboratorium IPA } \\
\text { 4. Dapat menjelaskan Pemeliharaan peralatan } \\
\text { laboratorium } \\
\text { 5. Dapat mengaplikasikan Sanitasi Lingkungan } \\
\text { dan pengolahan Limbah dilaboratorium IPA }\end{array}$ \\
\hline $\begin{array}{l}\text { BAB IV ILMUAN } \\
\text { TERLATIH } \\
\text { LABORATORIUM IPA }\end{array}$ & $\begin{array}{l}\text { 1. Dapat mengaplikasikan keterampilan } \\
\text { proses, Pengamatan, Pengklasifikasian, } \\
\text { Penginferensial, Peramalan/prediksi, } \\
\text { Pengkomunikasian, Pengkuran, Penggunaan } \\
\text { bilangan, Keterampilan dan eksperimen, } \\
\text { Keterampilan dalam pengamatan } \\
\text { 2. Dapat melakukan Penilaian keterampilan } \\
\text { proses Sikap seorang ilmuan IPA } \\
\text { 3. Dapat Membuat Laporan Praktikum }\end{array}$ \\
\hline $\begin{array}{l}\text { BAB IV PERENCANAAN } \\
\text { LABORATORIUM DAN }\end{array}$ & $\begin{array}{l}\text { 1. Dapat memahami Perencanaan } \\
\text { Laboratorium }\end{array}$ \\
\hline
\end{tabular}




\begin{tabular}{|c|c|}
\hline $\begin{array}{l}\text { PENGELOLAAN } \\
\text { LABORATORIUM }\end{array}$ & $\begin{array}{l}\text { 2. Dapat mengaplikasikan pelaksanaan } \\
\text { perencanaan laboratorium } \\
\text { 3. Dapat memahami Peneglolahan } \\
\text { laboratorium } \\
\text { 4. Dapat mengaplikasikan pelaksanaan } \\
\text { laboratorium }\end{array}$ \\
\hline $\begin{array}{l}\text { BAB V PENATAAN DAN } \\
\text { PEMELIHARAN ALAT DAN } \\
\text { BAHAN LABORATORIUM }\end{array}$ & $\begin{array}{l}\text { 1. Dapat memahami prinsip Penataan Alat dan } \\
\text { Bahan laboratorium } \\
\text { 2. Dapat mengaplikasikan prinsip penataan } \\
\text { alat dan bahan laboratorium } \\
\text { 3. Dapat memahami prinsip Pemeliharaan Alat } \\
\text { dan Bahan Laboratorium } \\
\text { 4. Dapat mengaplikasikan prinsip } \\
\text { pemeliharaan alat dan bahan laboratorium }\end{array}$ \\
\hline $\begin{array}{l}\text { BAB VI } \\
\text { PENGADMINISTRASIAN } \\
\text { LABORATORIUM }\end{array}$ & $\begin{array}{l}\text { 1. Dapat mendefinisikan administrasi lab IPA } \\
\text { 2. Dapat menyebutkan Daftar administrasi } \\
\text { laboratorium } \\
\text { 3. Dapat melakukan Inventarisasi alat dan } \\
\text { fasilitas laboratorium } \\
\text { 4. Dapat melakukan Administrasi stok } \\
\text { Laboratorium } \\
\text { 5. Dapat melakukan Administrasi kegiatan di } \\
\text { laboratorium } \\
\text { 6. Dapat melakukan Administrasi peminjaman } \\
\text { alat dan bahan } \\
\text { 7. Dapat melakukan Administrasi pengkodean } \\
\text { Alat dan bahan }\end{array}$ \\
\hline $\begin{array}{l}\text { BAB VII PENGAMANAN, } \\
\text { PERAWATAN, } \\
\text { PENGAWASAN }\end{array}$ & $\begin{array}{l}\text { 1. Dapat memahami Jenis perawatan } \\
\text { laboratorium IPA } \\
\text { 2. Dapat mendeskripsikan tugas pokok } \\
\text { Tenaga perawatan laboratorium ipa } \\
\text { 3. Dapat menrencanakan pembiayaan } \\
\text { perawatan laboratorium } \\
\text { 4. Dapat mendeskripsikan Bahan-bahan }\end{array}$ \\
\hline
\end{tabular}




\begin{tabular}{|l|l|}
\hline & \multicolumn{2}{|c|}{$\begin{array}{l}\text { perawatan } \\
\text { Dapat memberikan arahan Perawatan } \\
\text { peralatanyang ada di laboratorium IPA } \\
\end{array}$} & $\begin{array}{l}\text { 6apat melakukan Cara perawatan } \\
\text { laboratorium IPA } \\
\text { Dapat menganalisis Waktu perawatan alat } \\
\text { dan bahan laboratorium IPA }\end{array}$ \\
\hline $\begin{array}{l}\text { BAB VIII Keselamatan } \\
\text { kerja di laboratorium }\end{array}$ & 1. $\begin{array}{l}\text { Dapat mendeskripsikan cara Menjaga } \\
\text { keselamamatan dilaboratorium } \\
\text { Dapat menganalisis Kecelakaan yang } \\
\text { mungkin terjadi dilaboratorium }\end{array}$ \\
\hline
\end{tabular}




\section{BAB I \\ PENDAHULUAN}

\section{A. Sub Capaian Pembelajaran Matakuliah}

1. Mahasiswa mampu menjelaskan Latar Belakang peranan laboratorium dalam pembeljaran

2. Mahasiswa mampu menjelaskan tujuan pembelajaran laboratorium

3. Mahasiswa mampu memahami dasar-dasar hukum landasan pembelajaran laboratorium IPA

4. Mahasiswa mampu mengaplikasikan Keterkaitan kegiatan laboratorium dengan kurikulum 2013

5. Mahasiswa melalui kegiatan laboratorium mampu melakukan peningkatan pendidikan karakter dan literasi.

\section{B. Latar Belakang}

sekolah adalah sebuah sistem yang pendidikan formal yang menyelenggaran kegiatan pros belajar mengajar yang mana menutut Peraturan pemerintah (PP) Republik Indonesia No 13 Tahun 2015 yang telah diperbaharui menjadi PP Nomor 19 Tahun 2015 yang mempersyaratkan memiliki sebuah ruang laboratorium yang dijadikan sebagai tempat berlangsungnya praktikum atau sebagai tempat ruang percobaan dan penyelidikan yang dilakukan oleh guru dalam proses pembelajaran. Dalam sebuah sistem formal ini harus memiliki struktur organisasi yang memiliki tupoksi sesuai dengan tugas yang di emban dalam masing-masing jabatan tersebut, dalam laboratorium struktur organisasi terdiri atas tenaga pendidikan yang atur minimal dalam struktur organisasi tersebut terdiri atas kepala sekolah atau madrasah, wakil kepala sekolah, guru pengampu mata pelajaran sesuai dengan laboratorium, tenaga laboratorium atau laboran dan tenaga kebersihan. (Depdikbud, 1997). 
Mentri pendidikan nasional Republik Indonesia (RI) melalui Peraturan No 24 Tahun 2007 yang membahas maslah prasarana laboratorium pendidikan dasar (dikdas) atau Madrasah (MI-SD), Sekolah Menengah Pertama atau Madrasah Tsanawiyah (SMP-MTS) Sekolah Menengah Atas atau madrasa Aliyah (SMAMA)pda lampiran yang mengatur bahwa dalam dalam proses pembelajaran dengan menggunakan kurikulum 2013 dimana kegiatan pembelajaran dengan menggunakan pendekatan saintifik yang digunakan dalam K13 tersebut salah satu kegiatan yang harus ada dalam kegiatan pembelajaran adalah kegiatan penyeledikan atau dikenal dengan kegiatan praktikum sehingga laboratorium khususnya dalam pembelajaran IPA adalah sebuah sarana dan prasaraana yang harus ada daalamsekolah.

Perkembangan Ilmu Pengetahuan Alam yang pesat pada saat ini merupakan salah satu peran andil dalam sebuah peran dari laboratorium sebagai fungsi dalam menjalankan dalam proses pembelajaran. Dalam proses belajar mengajar atau yang biasa dikenal dengan istilah PBM pada mata pelajaran IPA khususnya laboratorium IPA memiliki peranan yang sangat strategis dengan melalui pelaksanaan kegiatan praktikum yang menjadi nyawa dalam proses pembelajaran pada mata pelajaran IPA. Proses kegiatan praktikum merupakan suatu perwujudan dari tujuan pendidikan yakni dalam hal mewujudkan pribadi yang utuh memahami dan terampil. Adanya laboratorium IPA yang menjadi andil dalam proses pembelajaran mempunyai fungsi antara lain:

1. Dalam rangka mencapai tujuan pembelajaran sesuai dengan kompetensi yang ada dalam pembelajaran IPA yang di aplikasikan dalam kegiatan proses belajar mengajar sehingga memiliki kualitas hasil yang sesuai dengan kemampuan yang diharapkan dalam penilaian pembelajaran IPA.

2. Memberikan pengutan dengan tujuan memperdalam dan memperkaya pemahaman peserta didik dalam memahami konsep dan prinsip IPA. 
Sehingga dengan adanya fungsi dari laboratorium dalam proses pembelajaran di IPA, adanya laboratorium IPA jenjang pendidikan terutama disekolah tingkat pertama SMP atau MTS merupak sebuah kebutuhan pokok yang dapat menunjang kegiatan dalam pembelajaran. Pada pembelajaran kurikulum 2013 dalam pembelajaran IPA kita mengenal adanya pendekatan saintificdalam melakukan proses ilmiah diantaranya mengamati (observasi), Menanya (merumuskan sebuah permasalahan) Mencoba atau melakukan eksperimen, mengolah dan menyajikan atau biasa dikenal dengan 5M dimana kegiatan tersebut sering kita jumpai dalam laboratorium.

Kenyataannya, banyak sekolah yang masih belum menggunakan laboratorium dalam proses pembelajarannya. Fakta ini berdasarkan hasil pemantauan Delapan Standar Nasional Pendidikan yang dilakukan oleh BSNP pada tahun 2010. Penyebabnya adalah kompetensi pengelolaan laboratorium belum dimiliki guru. Oleh karena itu, Permendiknas no 26 tahun 2008 tentang Standar Tenaga Laboratorium Sekolah/Madrasah dikeluarkan pemerintah. Kebijakan ini memberikan penghargaan kepada kepala laboratorium sekolah berupa ekuivalensi beban kerja 12 jam pelajaran (JP) sehingga diperlukan peningkatan kompetensi pengelola laboratorium. Sebagai upaya peningkatan kompetensi pengelola laboratorium dan implementasi kesesuaian pendekatan saintifik dengan kurikulum 2013 dalam pembelajaran IPA, maka disusun Buku Ajar Organisasi Laboratorium. Buku Ajar Organisasi Laboratorium yang telah disusun, diharapkan dapat menjadi panduan bagi guru IPA dalam melakukan kegiatan pembelajaran di laboratorium IPA. Selain itu, pengelola laboratorium dan guru IPA dapat bekerjasama untuk memanfaatkan laboratorium IPA secara optimal sehingga keterampilan proses sains peserta didik dapat meningkat dan keberhasilan implementasi kurikulum 2013 dapat tercapai. 


\section{Tujuan}

Dalam pelaksanaannya buku pengelolaan laboratorium IPA ini memiliki tujuan diantaranya adalah:

1. Sebgai pengangan mahasiswa dalam matakuliah pengelolaan laboratorium.

2. Sebagai acuan laboran atau tenaga laboratorium dalam pelaksanaan pengelolaan dan pemanfaatan laboratorium secara terstruktur dan optimal.

3. Segai acuan guru IPA dalam mengelola laboratorium sebagai sarana pelaksanaan atau implementasi pembelajaran pada kurikulum 2013.

\section{Dasar Hukum}

1. Standart nasional pendidikan yang diatur Peraturan Pemerintah RI pada tahun 2005 pada no 19. No 41 pada Standart Naional Pendidikan

2. Peraturan Menteri Pendidikan dan Kebudayaan Republik Indonesia Nomor 23 Tahun 2015 tentang Penumbuhan Budi Pekerti;

3. Peraturan Menteri Pendidikan dan Kebudayaan Republik Indonesia Nomor 20 Tahun 2016 Tentang Standar Kompetensi Lulusan Pendidikan Dasar dan Menengah;

4. Peraturan Menteri Pendidikan dan Kebudayaan Republik Indonesia Nomor 22 Tahun 2016 Tentang Standar Proses Pendidikan Dasar dan Menengah;

5. Peraturan Menteri Pendidikan dan Kebudayaan Republik Indonesia Nomor 21 Tahun 2016 Tentang Standar Isi Pendidikan Dasar dan Menengah;

6. Peraturan Menteri Pendidikan dan Kebudayaan Republik Indonesia Nomor 24 Tahun 2016 Tentang Kompetensi Inti dan Kompetensi Dasar Pelajaran pada Kurikulum 2013 pada Pendidikan Dasar dan Menengah;

7. Peraturan Menteri Pendidikan dan Kebudayaan Republik Indonesia Nomor 75 Tahun 2016 Tentang Komite Sekolah. 
8. Peraturan perundang-undangan Tahun 2003 no 20 dan No 78 (tambahan). yaitu tentang sistem pendidikan nasional.

9. Peraturan Menteri Pendidikan dan Kebudayaan Republik Indonesia Nomor 23 Tahun 2016 Tentang Standar Penilaian Pendidikan;

10. Peraturan Menteri Pendidikan Nasional Nomor 24 Tahun 2007 Tentang tentang Standar Sarana dan Prasarana Untuk Sekolah Dasar/Madrasah Ibtidaiyah (SD-MI), Sekolah Menengah Pertama/Madrasah Tsanawiyah (SMP-MTs), dan Sekolah Menengah Atas-Madrasah Aliyah (SMA-MA)

\section{E. Keterkaitan Kegiatan Laboratorium Dengan Kurikulum 2013}

Pada kurikulum 2013 laboratorium merupakan sebuah suatu komponen yang berperan penting dalam keterlaksanaan kurikum tersebut terutama pada laoratorium IPA. Dalam proses pembelajaran keberadaan laboratorium memberikan keaktivan kepada siswa dimana dalam hal ini siswa tidak hanya duduk diam menjelaskan penjellasan dari guru saja namun siswa menjadi piha yang aktiv. Setidaknya keberadaan laboratorium lebih menyeluruh memiliki 4 alasan yang kuat diantaranya:

1. Praktikum Meningkat Motivasi Belajar.

Dengan adanya pelaksanaan praktikum siswa dapat melibatkan seluruh indra pada siswa tersebut dalam rangka melakukan observasi yang dilakukan pada awal eksperimen ataupun dalam pelaksanaan eksperimen, sehingga hal ini dapat memotivasis siswa untuk belajar dengan baik.

2. Eksperimen merupakan keterampilan ilmiah dasar.

Eksperimen merupakan sebuah aktivitas yang dilkaukan dilaboratorium dan banyak dilkaukan oleh ilmuan dalam melakukan penemuan-penemuannya. Dalam pelaksanaan eksperimen beberapa keterampilan dasar mengamati, menanya, melakukan pengngukuran, melakukan perbandingkan, melakukan manipulasi dan keterampilan dasar lainnya. Sehingga dengan adanya ini melatihkan siswa untuk melakukan keterampilan ilmiah dasar. 
3. Menunjang pendekatan yang lebih realistik dari materi pelajaran. Praktikum memberikan kesempatan bagi peserta didik untuk menemukan teori, hukum, konsep dan membuktikan teori, hukum atau konsep ilmiah tersebut. Selain itu praktikum dalam pembelajaran IPA dapat membentuk ilustrasi bagi konsep dan prinsip ilmiah yang tadinya abstrak menjadi lebih kongkrit. Dari kegiatan tersebut dapat disimpulkan bahwa praktikum dapat menunjang pemahaman peserta didik terhadap materi pelajaran. Selanjutnya secara lebih rinci dapat dijelaskan bahwa, laboratorium IPA berperan penting dalam kegiatan pembelajaran yakni dengan menumbuhkan dan mengembangkan 5 aspek-aspek antara lain: (1) keterampilan dalam pengamatan, pengukuran, dan pengumpulan data, (2) kemampuan menyusun data dan menganalisis serta menafsirkan hasil pengamatan, (3) kemampuan menarik kesimpulan secara logis berdasarkan hasil eksperimen, mengembangkan model dan menyusun teori, (4) kemampuan mengomunikasikan secara jelas dan lengkap hasil-hasil percobaan, (5) keterampilan merancang percobaan, urutan kerja, dan pelaksanaannya, (6) keterampilan dalam memilih dan mempersiapkan peralatan dan bahan untuk percobaan, (7) keterampilan dalam menggunakan peralatan dan bahan, (8) kedisiplinan dalam mematuhi aturan dan tata tertib demi keselamatan kerja. Dengan demikian, ketika Sekolah Menengah Pertama (SMP) melaksanakan Kurikulum 2013, maka Pedoman Pengelolaan dan Pemanfaatan Laboratorium IPA ini sangat penting dalam rangka mendukung sekolah melaksanakan Kurikulum 2013 tersebut. Panduan ini juga berisi penjelasan dan contoh praktis mengenai penerapan pembelajaran dengan pendekatan saintifik, pembelajaran berbasis masalah, pembelajaran berbasis projek, pembelajaran kooperatif, discovery learning, dan pembelajaran dengan pendekatan komunikatif yang menggunakan laboratorium. 
F. Kegiatan Laboratorium dalam pengembangan penguatan literasi sains dan pendidikan karakter

Penguatan pendidikan karakter merupakan bagian dari sistem pendidikan nasional yang tertuang dalam RPJMN 20152019. Hal ini juga tertulis dalam UU Nomor 20 Tahun 2003 Tentang Sistem Pendidikan Nasional pasal 3. Pendidikan Nasional berfungsi mengembangkan kemampuan dan membentuk watak serta peradaban bangsa yang bermartabat dalam rangka mencerdaskan kehidupan bangsa, bertujuan untuk mengembangkan potensi peserta didik menjadi manusia yang beriman dan bertaqwa kepada Tuhan Yang Maha Esa, berakhlak mulia, sehat, berilmu, cakap, kreatif, mandiri, serta menjadi warga negara yang demokratis dan bertanggung jawab. Oleh karena itu, pendidikan karakter harus diajarkan pada semua jenjang pendidikan dan terintegrasi ke dalam mata pelajaran untuk memperkuat kepribadian, akhlak, dan moral peserta didik. Pada pembelajaran IPA, pendidikan karakter dapat diajarkan melalui kegiatan di laboratorium.

Pelaksanaan kegiatan di laboratorium, selain dapat mengajarkan pendidikan karakter juga dapat meningkatkan kemampuan literasi peserta didik. Hal ini disebabkan aktivitas dalam kegiatan laboratorium memenuhi komponen literasi seperti membuat dan membaca grafik, memasukkan, mengurut, menganalisis, serta menginterpretasi data kedalam bentuk tabel dan tulisan, membandingkan hasil percobaan dengan teori, mengatur dan menginterpretasi data dalam bentuk tabel dan tulisan, membandingkan hasil paraktikum dengan referensi, menyimpulkan hasil percobaan atau biasa dikenal dengan menganalisis dan kegiatan lainnnya. Dalam mengajarkan pendidikan karakter dan literasi dalam kegiatan laboratorium yang dikaitkan dengan kehidupan sehari-hari mahasiswa maka pemahaman karakter dan literasi ini akan dapat lebih di kenal, dipahami dan terapkan dalam kehidupan sehari-hari. 
Tabel 1.1: Keterkaitan Proses Pembelajaran Dilaboratorium Dengan Kegiatan Literasi

\begin{tabular}{|c|c|c|c|}
\hline Kegiatan & $\begin{array}{c}\text { Strategi Penguatan } \\
\text { Pendidikan } \\
\text { Karakter }\end{array}$ & $\begin{array}{c}\text { Pengembangan } \\
\text { Karakter }\end{array}$ & $\begin{array}{c}\text { Pengembangan } \\
\text { Literasi }\end{array}$ \\
\hline Perencanaan & 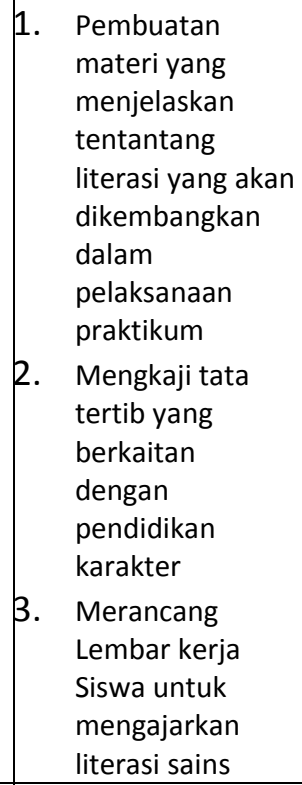 & $\begin{array}{ll}\text { 1. Kedisilinan } \\
\text { 2. Bertanggung } \\
\text { jawab } \\
\text { 3. Jujur } \\
\text { 4. Kejujuran } \\
\text { 5. Ketelitian } \\
\text { 6. Menghargai } \\
\text { adanya } \\
\text { berbedaan } \\
\text { dalam } \\
\text { kelompok } \\
\text { 7. Bekerja } \\
\text { dalam } \\
\text { kelompok } \\
\text { 8. Baik dalam } \\
\text { menyampaika } \\
\text { n pendapat }\end{array}$ & $\begin{array}{ll}\text { 1. } & \text { Mnafsirkan grafik } \\
\text { 2. } & \text { Menafsirkan data } \\
\text { 3. } & \text { Mengkaji literatur } \\
\text { 4. } & \text { Membaca atau } \\
& \text { mendeskripsikan } \\
& \text { data yang } \\
& \text { dihasilkan dalam } \\
& \text { kegiatan } \\
& \text { bereksperimen } \\
5 . & \text { Membuat laporan } \\
\text { 6. } & \text { Menyimpulkan } \\
& \text { hasil percobaan }\end{array}$ \\
\hline $\begin{array}{l}\text { Pengorganisasian } \\
\text { Kegiatan dan } \\
\text { Pemberian Tugas }\end{array}$ & 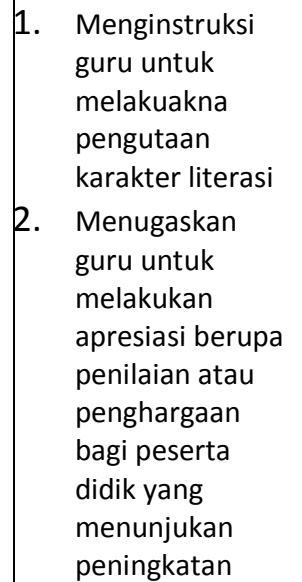 & 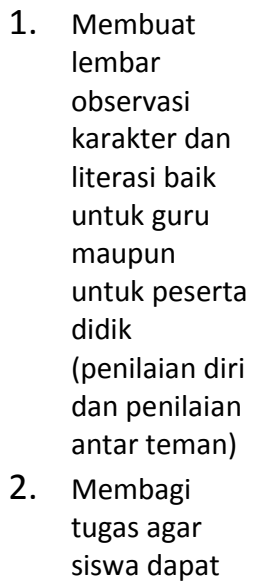 & \begin{tabular}{|l} 
1. \\
Membuat tugas \\
di LKPD yang \\
mendorong siswa \\
untuk membaca \\
referensi dan \\
mengembangkan \\
nalarnya. \\
2. \\
Menyiapkan \\
penghargaan baik \\
berupa nilai atau \\
reward lainnnya \\
yang memotivasi \\
siswa yang \\
meningkat \\
kemampuan
\end{tabular} \\
\hline
\end{tabular}




\begin{tabular}{|c|c|c|c|}
\hline & $\begin{array}{l}\text { dalam } \\
\text { pendidikan } \\
\text { karakter dan } \\
\text { literasinya }\end{array}$ & $\begin{array}{l}\text { melakukan } \\
\text { penilaian } \\
\text { antar teman } \\
\text { dalam } \\
\text { kelompok }\end{array}$ & literasinya \\
\hline $\begin{array}{l}\text { Pelaksanaan } \\
\text { Kegiatan }\end{array}$ & $\begin{array}{l}\text { 1. } \\
\text { memberikan } \\
\text { pengembangan } \\
\text { karakter dan } \\
\text { literasi dengan } \\
\text { cerita tentang } \\
\text { tokoh penemu } \\
\text { bidang sains } \\
\text { yang relevan } \\
\text { dengan topik } \\
\text { praktikum. } \\
\text { Memfasilitasi } \\
\text { siswa agar dapat } \\
\text { mengembangka } \\
\text { n karakter } \\
\text { selama kegiatan } \\
\text { praktikum, baik } \\
\text { melalui contoh, } \\
\text { simulasi, atau } \\
\text { arahan yang } \\
\text { bersifat verbal. } \\
\text { Melakukan } \\
\text { observasi dan } \\
\text { penilaia aspek } \\
\text { karakter dan } \\
\text { literasi dengan } \\
\text { dengan } \\
\text { mencatat } \\
\text { modus pada } \\
\text { buku jurnal. }\end{array}$ & $\begin{array}{ll}\text { 1. Disiplin } \\
\text { 2. Tanggung } \\
\text { jawab } \\
\text { 3. } \begin{array}{l}\text { Kecermatan/ } \\
\text { Ketelitian }\end{array} \\
\text { 4. Menghargai } \\
\text { perbedaan } \\
\text { 5. Bekerja } \\
\begin{array}{l}\text { dalam } \\
\text { kelompok } \\
\text { 6. Sopan dalam } \\
\text { menyampaika } \\
\text { n pendapat }\end{array}\end{array}$ & $\begin{array}{ll}\text { 1. } & \text { Membaca grafik } \\
\text { 2. } & \text { Membaca data } \\
\text { 3. } & \text { Membaca } \\
\text { referensi yang } \\
\text { mendukung hasil } \\
\text { praktikum } \\
\text { 4. Menginterpretasi } \\
\text { data }\end{array}$ \\
\hline Penutup & \begin{tabular}{|l} 
1. \\
Memfasilitasi \\
siswa untuk \\
membuat \\
pembahasan \\
hasil interpretasi
\end{tabular} & $\begin{array}{ll}\text { 1. Kejujuran } \\
\text { 2. Kemampuan } \\
\text { mengemukak } \\
\text { an pendapat } \\
\text { 3. Kecermatan/ }\end{array}$ & 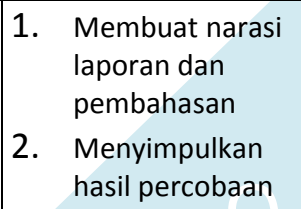 \\
\hline
\end{tabular}




\begin{tabular}{|c|c|c|}
\hline & \begin{tabular}{|l} 
2. \\
data \\
Memfasilitasi \\
peserta didik \\
untuk membuat \\
kesimpulan hasil \\
percobaan
\end{tabular} & ketelitian \\
\hline
\end{tabular}




\section{BAB II}

\section{ESENSI LABORATORIUM DAN PERANNYA DALAM IPA}

\section{A. Sub Capaian Pembelajaran Matakuliah}

1. Mahasiswa mampu memahami Pengertian Laboratorium IPA

2. Mahasiswa mampu menjelaskan Macam-macam laboratorium IPA

3. Mahasiswa mampu memahami Peran Laboratorium IPA

4. Mahasiswa mampu menjelaskan Pemeliharaan peralatan laboratorium

5. Dapat mengaplikasikan Sanitasi Lingkungan dan pengolahan Limbah dilaboratorium IPA

\section{B. Pengertian Laboratorium}

Menurut Suyidno (2018), Laboratorium IPA (selanjutnya disingkat lab IPA) adalah tempat penelitian ilmiah (pengamatan/eksperimen), pengukuran maupun pelatihan ilmiah. Laboratorium IPA dibuat untuk memungkinkan dilakukannya kegiatan tersebut secara terkendali.. Laboratorium IPA yang dimaksud pada ayat 1 meliputi laboratorium kimia, fisika dan biologi.

Laboratorium merupakan tempat dilakukannya percobaan dan penelitian. Tempat ini dapat berupa ruang tertutup, kamar atau ruang terbuka, atau kebun. Berdasarkan Depdikbud dalam Supriatna (2008), dalam pengertian yang terbatas, laboratorium merupakan suatu ruang tertutup dimana percobaan/eksperimen dan penelitian yang dilakukan. Laboratorium dilengkapi sejumlah peralatan yang dapat digunakan siswa untuk melakukan eksperimen atau percobaan dalam sains, melakukan pengujian dan analisis, melangsungkan penelitian ilmiah, ataupun paraktek pembelajaran dalam sains.

Laboratorium dapat bermacam macam jenisnya. Menurut Wirjosoemarto dkk (2004: 41) di Sekolah Menengah, 
umumnya jenis laboratorium disesuaikan dengan mata pelajaran yang membutuhkan laboratorium tersebut. Karena itu di sekolah-sekolah untuk pembelajaran IPA biasanya hanya dikenal Laboratorium Fisika, Laboratorium Kimia dan Laboratorium Biologi. Di SLTP mungkin hanya ada Laboratorium IPA saja. Di Perguruan Tinggi, untuk satu jurusan saja, mungkin terdapat banyak laboratorium. Kadang-kadang atas pertimbangan efisiensi, suatu ruangan laboratorium difungsikan sekaligus sebagai ruangan kelas untuk proses belajar mengajar. Laboratorium jenis ini dikenal sebagai Science classroom laboratory. Kelebihan jenis laboratorium ini bersifat multi guna.

\section{Macam-macam laboratorium IPA}

Laboratorium sebagai pusat reservasi dibedakan menjadi beberapa jenis berdasarkan fungsinya, antara lain :

1. Laboratorium Kimia

Laboratorium kimia digunakan untuk melaksanakan kegiatan praktikum yang berhubungan dengan analisa kimia kualitatif (kimia organik, kimia anorganik, dan biokimia) dan kimia kuantitatif (Penetapan kadar unsur maupun senyawa, Uji mutu maupun Quality Control).

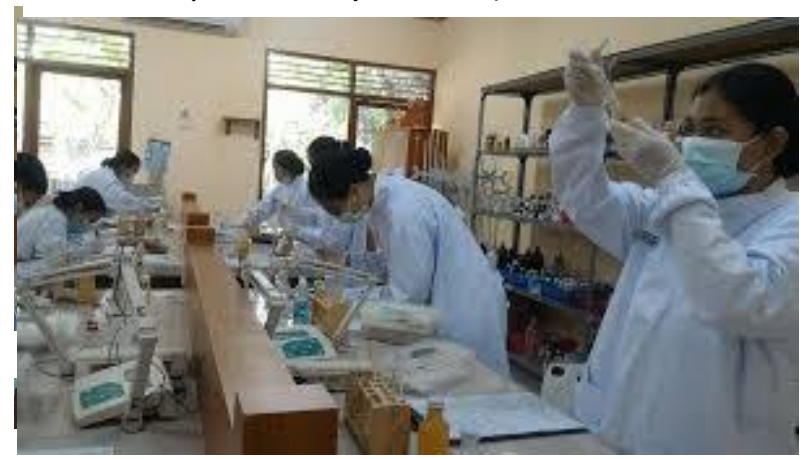

Gambar 2.1 Kegiatan Laboratorium Kimia

2. Laboratorium Fisika

Laboratorium Fisika digunakan untuk melaksanakan kegiatan praktikum yang berhubungan dengan analisa fisik suatu 
produk seperti uji kebocoran, uji kekentalan, dan uji organoleptik.

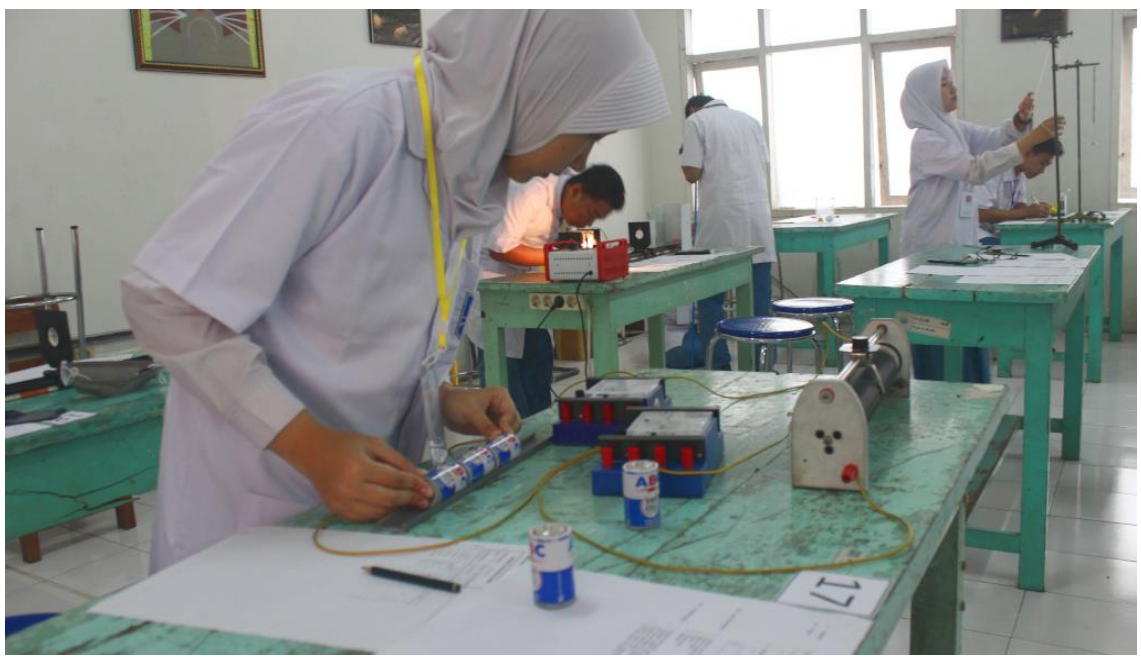

Gambar 2.2. Kegiatan Laboratorium Fisika

3. Laboratorium Mikrobiologi

Laboratorium Mikrobiologi digunakan untuk melaksanakan kegiatan praktikum yang berhubungan dengan analisa mikrobiologi seperti Uji bakteri gram positif dan negatif, uji bakteri patogen, uji kapang dan jamur. 


\section{BAB III}

\section{KOMPETENSI ILMUAN TERLATIH DI LABORATORIUM IPA}

\section{A. Sub Capaian Pembelajaran Matakuliah}

1. Mahasiswa mampu mengaplikasikan keterampilan proses, Pengamatan, Pengklasifikasian, Penginferensial, Peramalan/prediksi, Pengkomunikasian, Pengkuran, Penggunaan bilangan, Keterampilan dan eksperimen, Keterampilan dalam pengamatan

2. Mahasiswa mampu melakukan Penilaian keterampilan proses Sikap seorang ilmuan IPA

3. Mahasiswa mampu Membuat Laporan Praktikum

\section{B. Keterampilan IImuan IPA}

Ilmu pengetahuan alam atau yang biasa disingkat menjadi IPA merupakan kumpulan ilmu pengetahuan yang berhubungan dengan alam dan tersusun secara sistematis yang di dalamnya memuat berbagai gejala-gejala yang berhubungan dengan alam sekitar kita. Dalam pembelajaran IPA tidak hanya mengharapkan siswa menguasai konsep yang ada tetapi juga mengharapkan siswa untuk dapat melakukan suatu kegiatan penemuan 1 . Hakikat dalam pembelajaran IPA meliputi produk, proses, dan sikap. Produk akan berkaitan dengan pengetahuan yang akan didapatkan oleh siswa baik secara faktual, konseptual, maupun prosedural, sedangkan proses akan berkaitan dengan suatu kegiatan ilmiah dengan penggunaan metode-metode ilmiah yang meliputi kegiatan penelitian, percobaan, penemuan, pengamatan, dan kegiatan diskusi. Tujuan IPA sebagai proses yaitu mengharapkan siswa selama proses pembelajaran dapat memiliki sikap ilmiah sebagai hasil dari kegiatan ilmiah yang dilakukan oleh siswa2 . Pada pembelajaran IPA di sekolah menengah pertama pada kurikurum 2013 mengalami beberapa perubahan, dimana konsep pembelajaran dalam 
IPA dikembangkan menjadi mata pelajaran yang sifatnya terpadu sehinggamenjadi "IPA Terpadu", sehingga IPA tidak hanya sebagai disiplin keilmuan semata.

Konsep keterpaduan dalam mata pelajaran IPA pada kurikulum 2013 mengabungkan konsep bidang ilmu fisika, kimia, dan biologi, dan ilmu pengetahuan bumi dan antariksa. Dalam pembelajaran IPA terpadu ditandai dengan adanya keterkaitan semua disiplin ilmu yang telah disebutkan sebelumnya menjadi beberapa tema pembelajaran. Pembelajaran terpadu dapat diartikan sebagai pembelajaran yang menggabungkan beberapa bidang ilmu menjadi satu tema. Keterpaduan beberapa disiplin ilmu menjadi satu tema diharapkan dapat menjadikan pembelajaran IPA menjadi lebih bermakna, efektif, dan efisien.

\section{Keterampilan Proses Sains}

1. Pengertian Keterampilan Proses Sains

Pengertian Keterampilan Proses Sains Pengertian keterampilan proses sains banyak dikemukakan oleh para ahli pendidikan, istilah proses sains (Science Process) banyak digunakan, istilah ini menekankan pada pendekatan proses (processes approach) yang akan digunakan oleh guru dalam membahas materi yang mengacu pada prosesnya. Keterampilan proses sains merupakan keterampilan secara fisik dan mental yang berhubungan dengan kemampuan dasar yang harus dimiliki, dikuasi dan diaplikasikan ketika melakukan kegiatan ilmiah, sehingga dapat menemukan hal yang baru yang bersifat ilmiah25. Keterampilan proses sains (KPS) adalah kemampuan dasar yang harus dimiliki oleh setiap ilmuan untuk dapat melakukan suatu kegiatan penemuan, percobaan, maupun kegiatan ilmiah lainnya. Melihatnya pentingnya keterampilan proses sains untuk dimiliki oleh siswa, guru dapat mengembangkan keterampilan proses sains siswa sesuai dengan taraf 
perkembangan dan kemampuan yang dimiliki oleh siswa. Dengan mengembangkan keterampilan proses, dapat melatih siswa mandapatkan dan mengembangkan fakta serta konsep yang didapatkannya selama proses pembelajaran, hal tersebut dapat menumbuhkan dan meningkatkan pengalaman belajar siswa26 . Terdapat beberapa alasan yang menjadi dasar perlunya keterampilan proses dikembangkan dalam kegiatan belajar-mengajar, diantaranya yaitu:

a. Alasan pertama, pada era globalisasi seperti saat ini, ilmu pengetahuan meeningkat dengan sangat cepat, sehingga tidak lagi memungkinkan bagi guru menjelaskan semua materi dan konsep yang ada kepada siswa.

b. Alasan kedua, para pakar psikologi memiliki pendapat bahwa anakanak akan lebih muda mengerti dan mempelajari sesuatu yang sifatnya abstrak jika didalamnya disertakan dengan contoh yang

Keterampilan proses sains yang digabungkan dalam pembelajaran sains dapat melibatkan berbagai keterampilan yang ada baik keterampilan yang bersifat keilmuan, manual, maupun sosial. Melalui proses ilmiah maka akan terbentuk suatu produk pengetahuan, maka akan terbentuk pula sikap ilmiah. Sikap ilmiah diperlukan untuk menjaga keutuhan pengetahuan dan kelangsungan dalam perkembangannya28 . Keterampilan proses terdiri atas sejumlah keterampilan yang tidak dapat dipisahkan satu dengan lainnya, keterampilan proses sains dibagi keterampilan proses dasar dan keterampilan proses sains terpadu atau terintegrasi. 
2. Indikator Keterampilan Proses Sains

Keterampilan proses sains dasar terdiri atas beberapa indikator, diantaranya yaitu

a. Mengamati

Merupakan kegiatan yang berhubungan dengan panca indera kita, seperti mendegar, melihat, mencium, meraba, dan merasakan. Pada tahap mengamati orang akan mengatakan kejadian berdasarkan apa yang terlihat, yang terdengar, yang mereka cium, yang mereka rasakan, dan yang mereka raba. Pada tahap mengamati, siswa akan belajar untuk mengumpulkan petunjuk.

b. Menggolongkan / mengklasifikasikan

Menggolongkan berarti memilih berbagai objek atau peristiwa yang didasarkan pada kesamaan sifat khususnya, sehingga akan didapatkan sekelompok benda, atau objek, atau kejadian yang dimaksud. Pada kegiatan ini dikembangkan kemampuan siswa untuk menghimpun hasil pengamatan dan menyajikannya sebagai hasil pengamatan dalam bentuk tabel pengamatan.

c. Mengukur

Mengukur merupakan kegiatan membandingkan hasil yang diukur dengan satuan ukuran tertentu yang ditetapkan sebelumnya. Kegiatan mengukur membutuhkan alat-alat ukur yang sesuai dengan benda atau sesuatu yang akan diukur.

d. Mengkomunikasikan

Mengkomunikasikan merupakan kegiatan penyampaian fakta dan prinsip ilmu pengetahuan dalam berbagai bentuk, seperti misalnya dalam bentuk laporan, tabel, grafik, maupun dalam bentuk audio visual. 
e. Menginterpretasikan Data

Mengiterpretasikan data yaitu kegiatan memberikan makna pada data yang telah diperoleh dari hasil pengamatan, data tidak berarti apa-apa jika tidak dijelaskan dan artikan sebelumnya.

f. Memprediksi

Memprediksi merupakan kegiatan menduga sesuatu yang akan terjadi berdasarkan pola peristiwa, data, informasi, atau fakta yang telah terjadi sebelumnya. Kegiatan prediksi dilakukan dengan cara mengetahui kesamaan berdasarkan data dan pengetahuan yang telah ada, mengenal kebiasaan terjadinya suatu peristiwa berdasarkan pola kecenderungannya. Prediksi didasarkan pada kegiatan observasi dan penarikan kesimpulan mengenai hubungan antara peristiwa yang tengah diobservasi.

g. Menggunakan alat-bahan

Dalam kegiatan ilmiah penggunaan alat bahan akan berhubungan dengan kegiatan merangkai dan menggunakan alat dan bahan untuk kegiatan ilmiah yang akan dilakukan.

h. Melakukan percobaan

Melakukan percobaan merupakan suatu kemampuan dalam melakukan pengujian pada gagasan atau ide yang berdasarkan pada fakta, konsep, dan prinsip keilmuan sehingga didapatkan suatu informasi yang mendukung atau membantah ide tersebut.

i. Menyimpulkan

Keterampilan proses sains dasar yang terkahir yaitu menyimpulkan, menyimpulkan merupakan kegiatan penarikan keputusan yang didasarkan pada fakta, konsep, dan prinsip ilmu pengetahuan.

Untuk memahami lebih lanjut bagaimana keterampilan proes sain (lihat lampiran) 


\section{Membuat Laporan Praktikum}

Kegiatan proses belajar mengajar yang dilakukan dilaboratorium khususnya pada pembelajaran IPA hal yang paling penting yaitu adalah dalam Penyajian laporan yang merupakan ketrampilan dalam menyampaikan informasi. Dimana Kemampuan menyajikan informasi dengan jelas, logis dan singkat adalah sebuah keterampilan yang yang di butuhkan dalam proses akhir pembealjaran biasa dikenal dengan penulisan laporan yang dalam pembelajaran IPA dikenal dengan Penulisan laporan praktikum. Penulisan laporan tidaklah mudah, Walaupun laporan ditulis dengan format yang baku, namun memiliki bermacam-macam model dan pilihan. Laporanpraktikum memiliki unsur fleksibilitas, meskipun dalam penyusunan laporan praktikum harus mengikuti garis pedoman yang telah di sepakati oleh guru dalam pengampuh pelajarantersebut. Ciri Utama: Laporan harus singkat dan mempunyai alur yang logis. Naskah tidak boleh melebihi 6 halaman tulisan tangan normal (1800 kata), tanpa grafik dan lampiran. Laporan boleh dipendekkan asal memenuhi semua kriteria. Penyajian harus rapi, mudah dibaca, ditulis dengan tinta biru yang jelas atau tinta hitam; dapat juga diketik, pada satu sisi kertas (tidak bolak-balik). Penggunaan komputer sepenuhnya pilihan atau hak Anda, tetapi permasalahan komputer tidak akan diterima sebagai alasan untuk tidak mematuhi laporan. Ukuran huruf 11 atau 12 dan spasi 1 1/2. Penjiplakan: Laporan harus merupakan pekerjaan yang dilakukan oleh siswa. Hukuman atau sanksi keras bagi penjiplakan (menyalin pekerjaan orang lain tanpa mencantumkannya) akan diberlakukan sesuai ketentuan dalam aturan penulisan ilmiah. Pembuatan kalimat dalam penyusunan laporan, penyalinan diagram atau grafik yang disalin hendaknya menyertakan sumbernya. Dalam pembuatan laporan boleh bekerja sama untuk menguji ketelitian hasil dan memperdalam pemahaman siswa. Namun sebaiknya dalam menulis laporan tidak bergantung 
pada siswa lain dan pahami benar apa yang Anda tulis. Model: Sebagai laporan ilmiah, sebaiknya menulis dalam bentuk:

1. Past tense (tidak ada perintah seperti "Rangkai suatu meter........)

2. Orang ketiga (gunakan "saya" atau "kita" yang sering dipakai)

3. Tanpa ucapan sehari-hari (seperti "sangat bagus")

4. Tanpa penyingkatan (seperti "\&", pengganti dari kata "dan", frek., pengganti kata "frekuensi").

5. Semua diagram, daftar, grafik dan tabel sebaiknya juga dinomori, dan mempunyai judul pendek yang menyatakan informasi sesuai dengan apa yang diacu (dibahas)

Contoh pada penomoran gambar

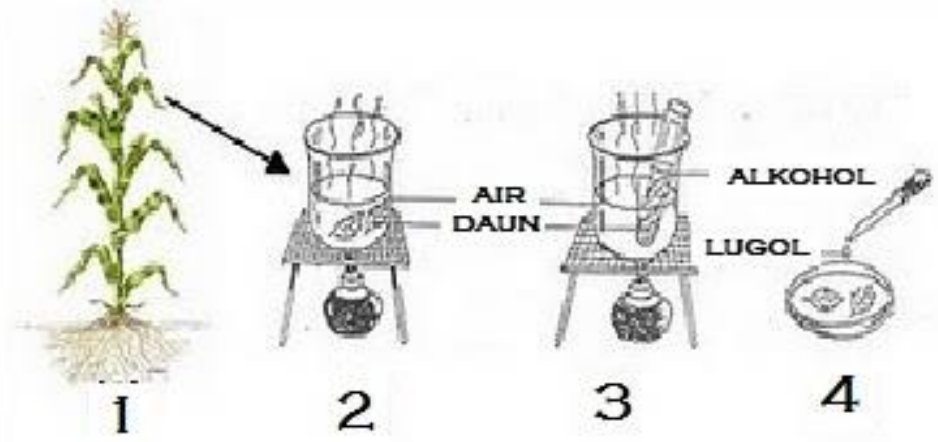

Gambar 1. Rangkaian Percobaan Foto sintesis dalam menghasilkan Amilum

Berikut contoh pada penomoran tabel Tabel 3. Hasil praktikum Pemuaian zat cair 


\begin{tabular}{|l|c|c|}
\hline Jenis Zat Cair & $\begin{array}{c}\text { Volume pada suhu } 30^{\circ} \mathrm{C} \\
(\mathbf{m L})\end{array}$ & $\begin{array}{c}\text { Volume pada suhu } 80^{\circ} \mathrm{C} \\
(\mathbf{m L})\end{array}$ \\
\hline Air & 400 & 404,2 \\
\hline Minyak goreng & 400 & 414,5 \\
\hline Alkohol & 400 & 422,0 \\
\hline
\end{tabular}

Berikut adalah contoh SISTEMATIKA PENULISAN LAPORAN: Berikut cakupan-cakupan yang perlu dicantumkan. Ingat, tidak perlu Anda mencantumkan bagian untuk "Tujuan" atau "Manfaat".

1. Judul dan Pengarang Berisi kata kunci yang jelas menggambarkan subyek laporan. Jangan menulis halaman judul terpisah dari laporan.

2. Abstrak (Intisari) Cukup satu paragraf ( \pm 80 kata) berisi kegiatan utama yang anda lakukan, prinsip/ metode kerja anda, hasil akhir perhitungan dalam bentuk numerik dan diskusi.

3. Pendahuluan Berisi tentang latar belakang praktikum (dilengkapi dengan pustaka yang menunjang), rumusan masalah dan tujuan dari praktikum serta rumusan hipotesis (Jika Ada)

4. Dasar Teori Berisikan pengulangan teori yang diperlukan dan persamaan-persamaan akhir/kunci yang digunakan. Tidak perlu menurunkan semua persamaan, tetapi tunjukkan sumber yang mendukung teori.

5. Metode Eksperimen Berisikan tentang identifikasi variabel-varibel percobaan dan mendefinisikan variabelvariabel secara operasional (Jika Ada), Alat dan Bahan yang digunakan serta detail langkah percobaan.

6. Hasil dan Analisis Kuantitas dan hasil eksperimen yang telah dihitung harus ditabulasikan dalam satu tabel, termasuk satu kolom untuk nilai teoritis/diterima. Rincian perhitungan tidak boleh disajikan. Bila perhitungan merupakan bagian penting eksperimen, 
berilah satu contoh perhitungan penuh, letakkan dalam lampiran dan mentabulasikan hasil-hasil perhitungan sisanya. Hasil Anda dalam bentuk grafik saat ini memberikan gambaran visual yang terbaik, hingga tabeltabel hasil mentah tidak diperlukan. Bila ada beberapa tahapan antara pengukuran dan grafik, hasil-hasil yang menampilkan grafik mungkin dapat dimasukkan dalam lampiran dengan bentuk tabel-tabel. Perkiraan ketidakpastian boleh dicantumkan sebagai hasil, dan boleh menguraikan bagaimana ketidakpastian diperkirakan bila tidak memenuhi data yang ada. Catat ciri-ciri 30 menarik dan luar biasa (misal perubahan kemiringan grafik) sebagai hasil atau dimasukkan dalam diskusi.

7. Diskusi bagian kegiatan yang yang sangat penting dan menantang dalam menulis. Dapat menjadi bagian besar dari eksperimen Anda bila hal ini sangat membantu. Berisikan pertimbangan hasil-hasil dan interpretasinya, mungkin langkah- langkah yang diambil dan anjurananjuran perbaikan pengukuran, membandingkan hasil dengan nilai teoritis/diterima atau nilai prediksi, dan ketidakpastian hasil eksperimen dari perhitungan. Bila ada pertanyaan dalam petunjuk praktikum yang dapat menjadi bahan diskusi, pertanyaan tidak harus dijawab terpisah dari pertanyaan dalam tugas, karena diharapkan dapat membantu pemahaman Anda bila melakukan eksperimen. Pemahaman tersebut dapat Anda masukkan dalam diskusi.

8. Kesimpulan merukan sebuah uraan dari jawaban pertanyaan atau dari penjelajasan ketercapaian tujuan dari pelksanaan praktikum dimana uraian baru yang jelas dari hasil-hasil utama, merupakan, inti ringkasan yang dicapai dalam diskusi. Secara normal, cukup satu paragraf meliputi data numerik pokok yang memenuhi, dengan ketidakpastian eksperimental dan 
membandingkannya dengan nilai teoritis. Dapat berupa "tanggapan" dari pendahuluan yang secara umum menguraikan petunjuk eksperimen. Boleh memberi komentar tentang signifikansi pekerjaan yang telah dilakukan.

9. Daftar pustaka atau biasa disebut dengan daftar rujukan merupakan sumber informasi yand didapat dalam penulisan laporan. Penulisan pustaka di sesuaikan dengan gaya yang dipakai, namun kebanyakan dalam penulisan putaka menggunakan atau menuliskan Nama, tahun terbit, judul buku atauartikel, kota terbit dan penerbit.

Sebgai contoh

Wulandari, F. E. (2016). Pengaruh Model Pembelajaran Berbasis Proyek untuk Melatihkan Keterampilan Proses Mahasiswa. PEDAGOGIA: Jurnal Pendidikan, 5(2), 247254.

10. Lampiran dalam penyertaan lampiran pada penulisan laporan hendaklah menggunakan atau diperuntukkan untuk data-data perhitungan, penurunan persamaan, tabel data mentah, jawaban pertanyaan dan lain-lain, terlepas dari naskah utama. 


\section{BAB IV \\ PENGELOLAAN LABORATORIUM}

\section{A. Sub Capaian Pembelajaran Matakuliah}

1. Mahasiswa mampu mengaplikasikan pelaksanaan perencanaan laboratorium.

2. Mahasiswa mampu memahami Pengelolaan laboratorium yaitu dapat mengaplikasikan pelaksanaan laboratorium.

\section{B. Dasar-Dasar Pengelolaan laboratorium}

1. Dasar- Dasar Prinsip Pengelolaan Laboratorium

Pengendalian, dan menjalankan atau mengurus manajemen merupakan sebuah prinsip penelolahan. Dimana dalam proses pengurusan manajemen yang mencangkup kegiatan perencanaan, pengorganisasian dan pengelolaan merupakan sebuah cara yang efektif dalam mengelola sumber daya yang ada salam sebuah sasaran manajemen. Mengatur dan memelihara alat dan bahan menjaga disiplin laboratorium, pemberdayaan laboratorium serta keselamatan laboratorium merupakan salah satu upaya dalam pengelolaan laboratorium. Dapat diartikan bahwa Pengelolaan laboratorium proses perawatan, pengadministrasian, pengamanan, perencanaan untuk mengembangkan laboratorium secara efektif dan efisien sesuai dengan apa yang diharapkan. Dalam pengelolaan laboratorium yang bertujuan untuk keselamatan yang terlibat dalam kegiatan laboratorium dan lingkungannya. Silitas Pengelolahaan dan penggunaan fasilitas laboratorium yang merupakan bagian dari sarana dan prasarana dalam pembelajaran IPA serta aktivitas atau kegiatan yang dilakukan di dalam lab untuk menjaga keberlanjutan atau sebagaimana fungsi laboratorium itu sendiri dalam proses pembelajaran. Dengan demikian, setiap orang yang terlibat dalam kegiatan laboratorium 
harus memiliki kesadaran dalam hal pemeliharaan, pengaturan dan keselamatan dalam kegiatan laboratorium.

Peningkatan Sumber Daya Manusia (SDM) merupakan Sebagian prinsip dasar yang harus diperhatikan dan dipenuhi dalam rangka pengelolaan laboratorium secara tempat. Setiap laboratorium pasti memiliki sumber daya manusia yang berperan mengelola aktivitas laboratorium dan fasilitas pendukungnya. Komponen pengelola laboratorium yang memiliki tanggung jawab merupakan sebuah apresiasi yang baik yang ditunjang atau sesuai dengan kompetensi yang dimiliki oleh laboran yang akan membuat kinerja laboratorium menjadi lebih efektif.

Berdasarkan pada peraturan mentri pendidikan nasional nomor 26 tahun 2008 dimana pemeritah menetapkan bahwa laboran atau tenaga laboratorium yang berada di sekolah atau madrasah harus memilki kompetensi dan standar kualifikasi sebgaai kepala laboratorium, laboran maupun tenaga tekhnis. Dalam pemenuhan standart kompetensi pengelola laboratorium sekolah yang mencangkup manajemen 9 alboratorium dengan standart operasional prosedur (SOP) peralatanperalatan yang ada di dalam laboratorium IPA yang sesuai dengan Standart operasional baku (SOB). Dalam kurikulum 2013 dalam pembelajaran IPA di SMP, kegiatan Pembelajaran IPA di tekankan pada kegiatan ilmiah dan keteampilan proses ilmiahyang meliputi kegiatan, mengamati (observasi) Mennaya atau membuat pertanyaan, Mencoba atau melakukan eksperimen, menalar, menyajikan dan menciptakan hal yang baru Peserta didik mengembangkan keterampilan proses sains (KPS) melalui kegiatan mengamati, mendeskripsikan, mengklasifikasikan, mengukur, melakukan percobaan, menganalisis data, dan menyimpulkan. Pada prinsipnya pembelajaran IPA di SMP harus banyak menekankan adanya kegiatan penemuan (discovery), dengan cara 
mengajak peserta didik sebagai subjek belajar berinteraksi dengan objek atau benda-benda yang dipelajari. Pengembangan sikap dan keterampilan ilmiah melalui KPS dengan pendekatan pembelajaran inkuiri. Kegiatan belajar terjadi minimal pada tiga konteks yaitu IPA dalam konteks kehidupan sehari-hari, lingkungan sekitar, dan masyarakat, sehingga ada keterkaitan antara sains, lingkungan, teknologi, dan masyarakat (salingtemas). Peran guru di dalam pembelajaran IPA adalah sebagai pemandu inkuiri (the leader of inquiry). Guru memiliki peran memfasilitasi, memotivasi, mengarahkan, dan membimbing peserta didik di dalam kegiatan inkuiri. Peran peserta didik dalam pembelajaran IPA adalah sebagai pelaku inkuiri (the inquirer). Dengan demikian, laboratorium IPA menjadi sarana yang sangatmutlak diperlukan dalam proses pembelajaran IPA secara inkuiri dan untuk pengembangan KPS.

2. Pengelolaan Lapboratorium IPA

Pengelolaan tentang laboratorium dan komponen yang ada di dalam lab IPA. Pengelolaan Im komponen di antaraya adalah pengelolah laboratorium yang terdiri dari Sumberdaya Manusia (SDM) dan yang dikelola dalam laboratorium yaitu( bahan laboratorium, alat laboratorium, fasilitas dan bangunan)

a. Pengelola Laboratorium, dalam pengelolaan laboratorium merupakan suatu komponen yang terpenting dalam laboratorium. Kelompok pengelolaan ini erupakan manusia atau sumber daya (SDA) yangsecara penuh bertanggung jawab dalam mobilitas laboratorium. Pada peraturan pemerintah pendidikan nasional no 26 Tahun 2008 setandart tenaga laboratorium pada jenjang madrasah atau sekolah yang terdiri dari kepala labotorium, laboran dan tekhnisi. Yang mana beban kerja pengelola laboratorium disesuaikan dengan jumlah dari siswa yang melakukan 
kegiatan praktikum dalam proses belajar mengajar dan jumlah siswa serta guru atau tenaga pengajar yang tergabung dalam kelompok ilmiah remaja (KIR). Dimana dalam tugasnya komponen pengelolaan laboratorium harus memahami dan mengerti tuboksi yang menjadi tanggungjawabnya. Dengan adanya pemahaman yang baik tentang tupoksi tupoksi pengelolaahan laboratorium maka diharapkan komponen ini saling bekerja sama untuk keberlangsungankaberadaan laboratorium sesuai dengan funsinya dalam proses belajar mengajar.

b. Gedung laboratorium, alat-alat laboratorium, fasilitas laboratorium dan bhan-bahan laboratorium merupakan komponen yang harus dikelola dengan baik, yang di lakukan untuk menjaga fungsi dan tujuan laboratorium. Beberapa contoh pelaksanaan pengelolaan laboratorium di sekolah antara lain:

1) Pengelolaan Fasilitas Laboratorium:
a) Peralatan Laboratorium
b) Pemasangan listrik
c) Pengaliran air
d) Pengaliran gas
e) Lingkungan sekolah

2) Pengelolaan peralatan Laboratorium, antara lain:
a) Perencanaan peralatan laboratorium laboratorium. mengenai jumlah dan jenis-jenis peralatan
b) Layout atau desain laboratorium yang disesuaikan dengan peralatan yang ada dilaboratorium.
c) Pengidentifikasian alat yang ada dilaboratorium
d) Pengadministrasian alat-alat yang ada dilaboratorium

3) Pengelolaan bahan-bahan praktikum: 
a) Melakukan identifikasi jumlah bahan yang ada

b) Melakukan persiapan tembat penggunaan bahan praktikum

c) Pengadministrasian beberapa bahan yang habis pakai atau yang tersisa dalam pemakaian praktikum.

c. Pengoptimalisasian Laboratorium IPA

Pengoptimalisasian laboratorium IPA merupakan sebuah usaha dalam hal penunjang pelaksanaan pebelajaran dalam hal ini adalah pelaksanaan praktikum sehinggga dapat memberikan sumbangsi yang baik dalam penggunaan laboratorium. Pelaksanaan penolahan laboratorium yang maksimal akan berdampak positif kepada peserta didik atau siswa dalam peningkatan kompetensi baik dari aspek kognitif, afektif, maupun secra psikomotor termasuk didalam nya keterampilan proses sains siswa. Optimalisasi pelaksanaan Lab diantaranya

1) Melakuakn penjadwlan laboratorium

2) Penataan alat laboratorium yang efisien

3) Efektifitas pemeliharaan laboratorium meliputi:

d. Administrasi Laboratorium

Pendokumentasian dengan proses pencatatan merupakan sebuah cara pendokumentasian dalam laboratorium. Dimana pengadministrasian ini memiliki tujuan:

1) Mengadakan pengamatan terhadap sumber daya manusia yang ada dalam laboratorium.

2) Sehingga dapat mempermudah pengecekan komponen sumberdaya laboratorium

3) Pelaksanaan operasionalisasi lab mempermudah fungsi dan kegiatan dalam pelayanan lab.

Manfaat administrasi Laboratorium IPA:

1) Sebuah cara mempermudah pengecekan laboratorium 
2) Sebuah cara untuk pencegahan penyalah gunaan fasilitas alat dan bahan praktikum

3) Cara yang dilakukan untuk meminimalisasi penekanan biaya operasional laboratorium

4) Pelkasanaan peningkatan kompetensi laboratorium

5) Pelaksanaan kegiatan peningkatan kerjasama

6) Adanya upaya melakukan penghematan dengan melaksanakan pemanfaatan bersama dalam hal penggunaan peralatan dan pemakaian bahan.

C. Desain Laboratorium

Jenis ruangan yang ada di dalam laboratorium meliputi:

a. Ruang pembelajaran sebagai tempat perlengkapan laboratorium termasuk meja, kursi, lemari dan rak ada didalamnya. Luas ruangan minimum dapat menampung satu rombongan belajar, sedikit-dikitnya 2.4m 2 /peserta didik, Jadi untuk laboratorium untuk kapasitas 40 peserta didik diperlukan luas lantai $(2.4 \times 40) \mathrm{m} 2=96 \mathrm{~m} 2$. Sedangkan untuk rombongan belajar dengan peserta didik kurang dari 20 orang, luas minimum ruang laboratorium $48 \mathrm{~m} 2$. Lebar minimum ruangan laboratorium IPA adalah $5 \mathrm{~m}$. Ruangan itu dapat berbentuk persegipanjang, misalnya (8x 13) $\mathrm{m} 2$ $=104 \mathrm{~m} 2$ atau $(9 \times 11) \mathrm{m} \mathrm{2=99m} 2$. Bentuk ruangan panjang ini mempunyai kelemahan pada jarak antara guru dan peserta didikyang dibelakang menjadijauh.Untukmengurangikelemahan tersebut disarankan agar ruangan itu berbentuk persegi.

b. Ruangan persiapan sebagai tempat guru dan laboran melakukan persiapan sebelumnya kegiatan pembelajaran agar kegiatan berjalan baik. Untuk laboratorium yang mempunyai luas lantai 100m 2 , sebaiknya memiliki ruang persiapan sekurangkurangnya $20 \mathrm{~m} 2$. Luas ruang penyimpanan dan persiapan minimum $18 \mathrm{~m} 2$. 
c. Ruangan penyimpanan untuk menyimpan alat-alat, peralatan dan bahanbahan yang belum digunakan. Idealnya ruang penyimpanan memerlukan ukuran minimal $(5 \times 4) \mathrm{m} 2=20 \mathrm{~m} 2$ agar dapat menyimpan lemari untuk zat-zat kimia.

d. Ruangan gelap untuk mengerjakan pemrosesan foto atau untuk percobaanpercobaan lain yang harus bebas cahaya.

Peralatan Laboratorium Peralatan Laboratorium sangat ditentukan oleh macam laboratorium. Sebuah SMP/MTs minimal memiliki satu ruangan Laboratorium IPA. Apabila sekolah mempunyai dana yang cukup, maka ruang laboratorium dapat dibagi menjadi Laboratorium IPA Fisika, Laboratorium IPA Biologi, Laboratorium IPA Kimia, dan Laboratorium IPBA (Ilmu Pengetahuan Bumi dan Antariksa. Pembagian tersebut akan memudahkan pengelola dan guru untuk menyiapkan alat dan bahan praktikum sehingga pelaksanaan praktikum dapat lebih efektif. Walaupun ada pembedaan jenis laboratorium, tetapi ada fasilitas laboratorium yang bersifat umum yang seharusnya ada dalam setiap laboratorium, seperti:

a. Meja. Meja ada beberapa macam, yaitu meja kerja untuk peserta didik meja kerja untuk guru, meja demonstrasi dan meja dinding.

b. Lemari. Berdasarkan wujud dan kegunaannya maka kebutuhan lemari suatu laboratorium adalah sebagai berikut: (a) Lemari biasa (lemari kaca), (b) Lemari gantung, dan (c) Lemari di bawah meja dinding 3) Rak 4) Bakcuci pada meja 5) Listrik (stop kontak pada setiap meja praktikan) 6) Pemanas (gas atau pembakar spiritus) Berikut adalah contoh-contoh denah desain Laboratorium IPA di Sekolah Menengah Pertama. 


\section{BAB V}

\section{PENATAAN DAN PEMELIHARAN ALAT DAN BAHAN LABORATORIUM}

\section{A. Sub Capaian Pembelajaran Mata Kuliah}

1. Mahasiswa mampu memahami prinsip Penataan Alat dan Bahan laboratorium

2. Mahasiswa mampu mengaplikasikan prinsip penataan alat dan bahan laboratorium

3. Mahasiswa mampu memahami prinsip Pemeliharaan Alat dan Bahan Laboratorium

4. Mahasiswa mampu mengaplikasikan prinsip pemeliharaan alat dan bahan laboratorium

\section{B. Penataan Alat dan Bahan Laboratorium}

Penataan berkaitan dengan pengklasifikasian, penggunaan, penempatan, penyimpanan, dan perawatannya. Penataan alat dan bahan laboratorium bergantung kepada tata letak laboratorium, fasilitas yang tersedia di laboratorium (ruang praktikum, ruang persiapan, ruang penyimpanan khusus, gudang, tempat penyimpanan alat dan bahan seperti lemari, rak, dan kabinet), keadaan alat (jenis alat, jenis bahan pembuat alat, atau jenis percobaan) dan kepentingan pemakai laboratorium yang ditentukan oleh kemudahan dicari dan dicapai serta keamanan dalam pengambilan dan penyimpanannya. Hal-hal yang harus diperhatikan saat melakukan penataan alat dan bahan laboratorium adalah: 1) alat yang akan ditata atau disimpan dalam keadaan bersih; 2) alat dan bahan didata dan diperiksa sesuai dengan jenis, sifat fisik, jumlah, dan harga; 3) alat dan bahan dikelompokkan sesuai dengan keilmuan (fisika, biologi, ataupun kimia) dan katalog yang digunakan. 
Penataan alat dan bahan laboratorium bertujuan untuk:

1. Penggunaan alat dan bahan laboratorium dapat maksimal

2. Memberikan hasil yang maksimal dengan pendanaan yang minimal

3. Memudahkan untuk melakukan pengawasan

4. Mengurangi hambatan yang muncul ketika melakukan tugas yang menjadi tanggung jawabnya

5. Memberikan keamanan dan kenyamanan bagi pengguna laboratorium

Peralatan laboratorium atau biasa disebut dengan alat laboratorium merupakan alat-alat kerja yang dipergunakan untuk pengukuran, pengujian, kalibrasi, ataupun produksi dalam skala terbatas. Peralatan laboratorium dikelompokkan kedalam tiga kategori, yaitu: 1) peralatan kategori 1 adalah suatu peralatan yang cara pengoperasian dan perawatannya mudah, resiko penggunaan rendah, akurasi pengukurannya rendah, cara kerjanya sederhana, dan sistem pengoperasiannya hanya menggunakan panduan; 2) peralatan kategori 2 adalah suatu peralatan yang cara pengoperasian dan perawatannya sedang, resiko penggunaan sedang, akurasi pengukurannya sedang, cara kerjanya tidak begitu rumit, dan sistem pengoperasiannya membutuhkan pelatihan tertentu; 3) peralatan kategori 3 adalah suatu peralatan yang cara pengoperasian dan perawatannya sulit, resiko penggunaan tinggi, akurasi pengukurannya tinggi, cara kerjanya rumit, dan sistem pengoperasiannya membutuhkan pelatihan tertentu dan bersertifikat.

Alat-alat laboratorium digunakan untuk kegiatan pendidikan dan pengajaran, penelitian, pengabdian ke masyarakat, maupun studi tertentu sehingga alat-alat tersebut harus selalu siap pakai apabila digunakan sewaktu-waktu. Agar alat selalu siap pakai maka harus dalam kondisi baik. Alat-alat laboratorium dikatakan dalam kondisi baik apabila memenuhi persyaratan siap untuk dipakai, bersih, berfungsi dengan baik, dan terkalibrasi. Alat-alat laboratorium sebaiknya dikelompokkan berdasarkan 
penggunaannya. Hal ini juga dapat diterapkan di laboratorium IPA. Alat-alat yang digunakan di laboratorium IPA dikelompokkan dalam beberapa kategori, diantaranya adalah:

1. Alat kegiatan

Merupakan alat yang digunakan untuk melakukan pengamatan dan pengukuran. Sebelum digunakan, harus dilakukan kalibrasi terlebih dahulu untuk mendapatkan data yang akurat. Contoh alat-alat kegiatan antara lain elektroskop, mikroskop, alat optik, kalorimeter, alat pengukur massa (neraca ohauss, neraca digital, neraca pegas), kalorimeter, spektroskop, anemometer, multitester, dsb

2. Alat-alat dasar

Merupakan alat yang digunakan untuk melengkapi alat-alat percobaan. Contohnya antara lain tabung reaksi, erlenmeyer, gelas kimia, selang plastik, pipa kapiler, bunsen, kasa, kaki tiga, baterai, power supply, kawat, aluminium, dsb

3. Alat peraga

Merupakan alat yang digunakan untuk demonstrasi atau memperagakan struktur objek IPA secara rinci. Contoh alat peraga antara lain kit IPA, torso, diorama, model, insektarium

4. Charta, foto atau bagan

Merupakan alat yang digunakan untuk menjelaskan suatu konsep IPA. Dapat berupa tabel, diagram yang memuat informasi inti dan keterkaitan antar konsep

5. Perkakas dan alat penunjang

Merupakan alat yang digunakan untuk memperbaiki alat-alat laboratorium yang rusak dan melindungi diri saat melakukan percobaan. Contohnya antara lain obeng, tang, bor, soldier, gunting, alat pemadam kebakaran, masker, jas laboratorium

Penataan alat-alat laboratorium memperhatikan prinsipprinsip sebagai berikut:

1. Kemudahan dan keamanan dalam mencari dan mengambilnya

2. Fungsi alat sebagai alat ukur atau hanya sebagai penyimpan bahan 
3. Jenis bahan dasar. Alat-alat dikelompokkan berdasarkan bahan (terbuat dari kaca, logam, atau porselen). Alat-alat yang terbuat dari logam harus dipisah dari bahan kaca atau porselen

4. Tingkat resiko. Alat-alat laboratorium termasuk ke dalam alat yang mudah rusak, mudah pecah, maupun menggunakan daya yang tinggi terutama untuk alat-alat listrik

5. Kualitas alat termasuk kecanggihan dan ketelitian

6. Kuantitas alat termasuk kelangkaannya

7. Bentuk dan ukuran alat

8. Berat alat. Alat-alat yang berat tidak diletakkan di tempat yang tinggi untuk memudahkan pengambilan dan penyimpanannya

9. Harga alat. Alat-alat yang mahal disimpan dalam tempat yang aman dan terkunci

10. Alat-alat berupa set/kit harus diletakkan dalam kotak perangkatnya

11. Alat-alat yang menggunakan baterai kering harus sering diperiksa. Apabila akan disimpan maka baterai kering harus dilepas

12. Frekuensi penggunaan. Alat-alat yang sering digunakan diletakkan di tempat yang mudah dijangkau

Bahan laboratorium adalah segala sesuatu yang diolah atau digunakan dalam kegiatan percobaan, pengujian, maupun produksi dalam skala terbatas. Bahan laboratorium dikelompokkan kedalam dua kategori yaitu: 1) bahan khusus, suatu bahan yang memerlukan perlakuan dan persyaratan khusus dalam hal penyimpanan, memiliki sifat fisik eksplosif, korosif, iritan dan labil, memiliki sifat kimia berbahaya dan beracun, serta memerlukan kemurnian tinggi untuk persyaratan metodenya dan 2) bahan umum, suatu bahan yang tidak memerlukan perlakuan dan persyaratan khusus dalam hal penyimpanan, memiliki sifat fisik tidak eksplosif, tidak korosif, tidak iritan, dan stabil, memiliki sifat kimia non toksik dan tidak berbahaya, serta tidak memerlukan kemurnian tinggi.

Bahan laboratorium yang memerlukan penanganan lebih hati-hati adalah bahan-bahan kimia. Bahan kimia ditata dan 
disimpan dengan benar untuk menghindari resiko kecelakaan di laboratorium. Hal-hal yang harus diperhatikan dalam penataan dan penyimpanan bahan kimia antara lain: aspek pemisahan, tingkat resiko bahaya, pelabelan, fasilitas penyimpanan, wadah sekunder, bahan kadaluarsa, inventarisasi, dan informasi resiko bahaya. Penataan dan penyimpanan bahan-bahan kimia memperhatikan prinsip-prinsip sebagai berikut:

1. Disusun berurutan sesuai abjad

2. Berdasarkan klasifikasi atau golongan

3. Berdasarkan sifat

4. Pedoman umum penyimpanan

5. Dikontrol secara periodik

6. Aman, bahan kimia harus disimpan dengan aman untuk menghindari kecelakaan maupun kejadian pencurian

7. Mudah dicari, perlu diberi tanda atau label pada setiap tempat penyimpanan bahan kimia untuk memudahkan mencari letak bahan kimia

8. Mudah diambil, bahan mudah diambil dari tempat penyimpanan dan setelah digunakan dikembalikan ke tempat semula

9. Disimpan pada tempat yang sesuai dan terpisah, misalkan botol besar di sebelah bawah, botol kecil di sebelah atas lemari atau tempat khusus

Pemberian label informasi pada setiap wadah penyimpanan bahan kimia perlu dilakukan untuk mengetahui sifat kimia dan fisik serta mencegah resiko kecelakaan. Informasi yang dapat dicantumkan pada wadah penyimpanan antara lain: nama kimia dan rumusnya, konsentrasi, tanggal penerimaan, tanggal pembuatan, nama orang yang membuat reagen, tingkat bahaya, klasifikasi lokasi penyimpanan, nama dan alamat pabrik. Selain pemberian label informasi, harus diperhatikan pula kelayakan suatu wadah untuk menyimpan bahan kimia. Secara umum, tempat penyimpanan bahan kimia harus bersih, kering, jauh dari sumber panas atau cahaya matahari secara langsung, dan dilengkapi dengan ventilasi menuju ruang asap atau keluar ruangan. 
Terdapat syarat tertentu untuk tempat penyimpanan dilihat dari sifat bahan kimia. Syarat tersebut antara lain:

1. Bahan beracun

Ruangan dingin dan memiliki ventilasi

Jauh dari bahaya kebakaran

Terpisah dari bahan kimia lain yang memiliki kemungkinan untuk bereaksi

Kran dari saluran gas harus dalam keadaan tertutup apabila tidak digunakan

Disediakan alat pelindung diri seperti jas laboratorium, masker, sarung tangan

2. Bahan korosif

Ruangan dingin dan memiliki ventilasi

Wadah tertutup dan beretiket

Terpisah dari bahan-bahan atau zat-zat beracun

3. Bahan mudah terbakar

Dibagi kedalam tiga kelompok, yaitu:

a) Cairan yang terbakar dibawah suhu $-4^{\circ} \mathrm{C}$, contohnya eter

b) Cairan yang dapat terbakar pada suhu antara $-4^{\circ} \mathrm{C}$ sampai $21^{\circ} \mathrm{C}$, contohnya etanol

c) Cairan yang dapat terbakar pada suhu antara $21^{\circ} \mathrm{C}$ sampai $93,5^{\circ} \mathrm{C}$, contohnya kerosin

Ruangan dingin dan memiliki ventilasi

Menjauhkan dari sumber panas atau api

Memiliki alat pemadam kebakaran

4. Bahan mudah meledak

$>$ Ruangan dingin dan memiliki ventilasi

- Menjauhkan dari sumber panas atau api

- Hindarkan dari gesekan atau tumbukan mekanis

5. Bahan oksidator

Ruangan dingin dan memiliki ventilasi

Menjauhkan dari sumber panas atau api

Menjauhkan dari bahan-bahan yang mudah terbakar

6. Bahan reaktif terhadap air

Ruangan dingin, kering dan memiliki ventilasi 
$>$ Menjauhkan dari sumber panas atau api

Tempat penyimpanan kedap air

Tersedia alat pemadam kebakaran tanpa air $\left(\mathrm{CO}_{2}, d r y\right.$ powder)

7. Bahan reaktif terhadap asam

Ruangan dingin dan memiliki ventilasi

Menjauhkan dari sumber panas atau api dan asam

Tempat penyimpanan didesain agar tidak memunculkan kemungkinan terbentuknya kantong-kantong hidrogen

Disediakan alat pelindung diri seperti jas laboratorium, masker, sarung tangan

8. Gas bertekanan

Ruangan dingin dan tidak terkena cahaya matahari secara langsung

Disimpan dalam keadaan tegak berdiri dan terikat

Menjauhkan dari sumber panas atau api

Menjauhkan dari bahan korosif yang dapat merusak kran dan katub

C. Pemeliharaan Alat dan Bahan Laboratorium

Pemeliharaan terhadap alat dan bahan laboratorium perlu dilakukan secara rutin untuk menghindari kerusakan dan dapat bertahan lama. Pemeliharaan secara rutin dapat dilakukan dengan cara sebagai berikut:

1. Pemeriksaan kelengkapan sebelum alat dan bahan digunakan

2. Alat harus dibersihkan terlebih dahulu sebelum digunakan

3. Alat harus dibersihkan kembali setelah digunakan dan disimpan ke tempatnya dalam keadaan bersih dan kering

4. Kelengkapan alat harus diperiksa sebelum disimpan

5. Selalu membaca buku petunjuk atau panduan penggunaan alat dan bahan sebelum menggunakannya terutama untuk alat yang cara kerjanya rumit

6. Selalu mengecek kelangkapan dan membaca buku petunjuk terhadap alat dan bahan laboratorium yang baru datang 
Setiap alat memiliki karakteristik yang berbeda sehingga memerlukan pemeliharaan khusus untuk masing-masing alat. Pemeliharaan alat dikelompokkan menjadi:

1. Pemeliharaan alat gelas

Beberapa alat laboratorium yang terbuat dari gelas ada yang tahan terhadap panas dan tidak. Tidak menggunakan gelas yang tidak tahan panas untuk percobaan yang membutuhkan pemanasan. Setelah digunakan, alat harus dibersihkan atau dicuci dan disimpan dalam keadaan kering

2. Pemeliharaan alat optik

Alat-alat optik seperti lensa terutama bagian filternya harus diperiksa secara berkala untuk menghindari munculnya jamur atau kotoran. Apabila terdapat jamur atau kotoran harus segera dibersihkan. Tempat penyimpanan alat-alat optikhendaknya diberi lampu penerangan untuk menghindari munculnya jamur

3. Pemeliharaan alat listrik

Alat-alat yang menggunakan listrik sebagai sumber tenaga harus dalam keadaan off setelah digunakan kemudian mencabut stopkontak untuk memutus aliran listrik. Alat yang menggunakan baterai harus dilakukan penggantian secara berkala. Pada saat menggunakan alat-alat listrik pendampingan guru sangat diperlukan untuk menghindari resiko kecelakaan di laboratorium

4. Pemeliharaan alat logam

Alat-alat yang terbuat dari logam rentan mengalami karat. Saat penyimpanan harus dalam keadaan kering dan terpisah dari bahan-bahan kimia yang bersifat korosif. Sebelum disimpan, harus dibersihkan terlebih dahulu dengan cara dilap menggunakan kain kemudian diolesi dengan minyak oli, paraffin cair, ataupun minyak rem

5. Pemeliharaan alat kayu

Alat-alat yang terbuat dari kayu rentan terhadap hewan pemakan kayu. Pemeliharaan yang dapat dilakukan adalah 
menyemprotkan pestisida atau melapisi dengan cat. Pada saat disimpan alat harus dalam keadaan kering

6. Pemeliharaan alat porselen

Alat porselen mudah retak dan pecah sehingga saat penyimpanan hindarkan dengan benturan dan disimpan di tempat yang aman

7. Pemeliharaan alat karet

Alat-alat laboratorium yang terbuat dari karet mudah meleleh dan lengket. Selain itu alat ini juga tidak tahan terhadap panas karena akan menghilangkan sifat elastisitasnya. Pada saat penyimpanan, alat harus dalam keadaan bersih dan kering dan apabila diperlukan diberikan taburan bedak di atas permukaannya 


\section{BAB VI \\ PENGADMINISTRASIAN LABORATORIUM}

\section{A. Sub Capaian Pembelajaran mata Kuliah}

1. Mahasiswa Mampu mendefinisikan administrasi lab IPA

2. Mahasiswa Mampu menyebutkan Daftar administrasi laboratorium

3. Mahasiswa Mampu melakukan Inventarisasi alat dan fasilitas laboratorium

4. Mahasiswa Mampu melakukan Administrasi stok Laboratorium

5. Mahasiswa Mampu melakukan Administrasi kegiatan di laboratorium

6. Mahasiswa Mampu melakukan Administrasi peminjaman alat dan bahan

7. Mahasiswa Mampu melakukan Administrasi pengkodean Alat dan bahan

\section{B. Definisi Laboratorium IPA}

Laboratorium merupakan tempat untuk melakukan kegiatan penyelidikan dan percobaan. Fasilitas atau tempat yang digunakan untuk penyelidikan bisa didalam ruangan tertup ataupun di ruangan terbuka, misalnya lapangan, sungai. Ruangan tertutup atau biasa di sebut dengan laboratorium dimana tempat dilakukannya percobaan dan penyelidikan. Laboratorium menjadi tempat kegiatan pembelajaran secara praktek dengan menggunakan alat dan bahan tertentu yang tidak dapat dibawa ke ruang kelas.

Salah satu pembelajaran di tingkat sekolah menengah yang memerlukan penggunaan laboratorium adalah pembelajaran IPA. Kegiatan yang dilakukan di dalam laboratorium dapat mendukung proses pembelajaran IPA karena IPA mempelajari berbagai fenomena alam dan dilandasi dengan eksperimen. Pentingnya 
kegiatan eksperimen atau percobaan dalam pembelajaran IPA mensyaratkan tersedianya laboratorium IPA di sekolah menengah terutama sekolah menengah pertama (SMP).

Landasan hukum tentang laboratorium adalah PP no 19 tahun 2005 tentang Standar Nasional Pendidikan yang diperbaharui dengan PP no 13 tahun 2015 tentang Perubahan Kedua PP Nomor 19 Tahun 2005 bahwa setiap sekolah memiliki laboratorium. Diperjelas dengan Peraturan Menteri Pendidikan Nasional Republik Indonesia Nomor 24 Tahun 2007 tentang Standar Sarana dan Prasarana Untuk Sekolah Dasar/Madrasah Ibtidaiyah (SD/MI), Sekolah Menengah Pertama/Madrasah Tsanawiyah (SMP/MTs), dan Sekolah Menengah Atas/Madrasah Aliyah (SMA/MA) bahwa SMP sekurang-kurangnya memiliki laboratorium IPA. BSNP (2006) menyatakan bahwa sekolah harus memiliki laboratorium selain peralatan pendidikan lainnya.

Laboratorium IPA merupakan tempat bagi guru dan siswa untuk menemukan dan menyelesaikan masalah IPA melalui kegiatan praktikum. Kegiatan praktikum memiliki peranan penting dalam mengembangkan pendekatan saintifik dan keterampilan proses sains siswa seperti yang disebutkan dalam Kurikulum 2013. Selain itu, laboratorium IPA juga berperan dalam mengembangkan ilmu pengetahuan alam sehingga dapat meningkatkan kualitas dan kompetensi siswa dalam menghadapi persaingan dan tantangan di masa depan. Ditinjau dari fungsinya, laboratorium memiliki beberapa fungsi antara lain: 1) mendukung pencapaian tujuan proses belajar mengajar sehingga dapat meningkatkan kualitas pembelajaran; 2) memberikan penguatan, memperkaya, dan memperdalam pemahaman siswa tentang konsep-konsep IPA; 3) melatih kebiasaan dan keterampilan ilmiah; dan 4) mendidik siswa menjadi individu yang teliti, kritis, dan kreatif.

Adapun tujuan penggunaan laboratorium IPA adalah: 1) mengembangkan kompetensi siswa secara menyeluruh dari segi kognitif, afektif, dan psikomotorik; 2) mengembangkan keterampilan sosial siswa; 3) mengembangkan keterampilan siswa dalam pengamatan, penggunaan alat, dan pengumpulan data; 4) 
melatih siswa bekerja secara teliti, hati-hati, cermat, dan disiplin; 5) mengembangkan proses berpikir siswa melalui analisis data dan penarikan kesimpulan; dan 6) mengembangkan sikap ilmiah seperti jujur, kerjasama, dan tanggung jawab. Melihat peran penting laboratorium maka laboratorium IPA menjadi suatu kebutuhan dalam menunjang proses pembelajaran. Hal ini sesuai dengan cara penyampaian pembelajaran IPA yang tertuang di kurikulum 2013 bahwa siswa belajar melalui penemuan dan melakukan proses ilmiah yang meliputi mengamati, menanya, mencoba, mengolah, dan menyajikan atau disebut $5 \mathrm{M}$.

\section{Daftar Administrasi Laboratorium}

Pengelolaan laboratorium IPA harus dilakukan secara sistematis, terarah, dan terukur untuk mendapatkan hasil yang optimal. Laboratorium yang memiliki pengelolaan baik memiliki karakteristik sebagai berikut:

1. Alat dan bahan laboratorium mendukung peningkatan kualitas pembelajaran atau kegiatan praktikum

2. Pemasangan alat hemat waktu dan biaya

3. Lampu, ventilasi, sanitasi, air bersih, keselamatan kerja memenuhi persyaratan sehingga laboratorium aman dan sehat

4. Alat dan bahan laboratorium dalam keadaan baik dan siap pakai serta aman

5. Semua kegiatan laboratorium dapat dikontrol dengan implementasi administrasi laboratorium yang baik

6. Memiliki tampilan visual yang menarik dan menyenangkan, iklim kerja yang baik, kesejahteraan lahir dan batin sehingga kebutuhan psikologis terpenuhi

Dimensi pengelolaan laboratorium antara lain organisasi laboratorium, administrasi laboratorium (inventarisasi alat dan fasilitas laboratorium, administrasi penggunaan laboratorium, administrasi peminjaman alat-alat laboratorium, administrasi pemeliharaan alat-alat laboratorium), dan keselamatan kerja di laboratorium. Pada bab ini, fokus pembahasan kepada administrasi laboratorium. Administrasi laboratorium merupakan kegiatan 
pendokumentasian sarana prasarana dan aktivitas laboratorium agar fasilitas dan aktivitas laboratorium dapat terorganisir dengan baik dan sistematis. Dalam kaitannya dengan fasilitas laboratorium, administrasi laboratorium bertujuan untuk mencegah kehilangan atau penyalahgunaan, memudahkan dalam pemeliharaan, mencegah duplikasi alat dan bahan, dan memudahkan dalam pengecekan.

Beberapa tujuan dalam melakukan administrasi laboratorium antara lain:

1. Menekan biaya operasional laboratorium

2. Meningkatkan kualitas kerja sumber daya manusia

3. Meningkatkan kepuasan pengguna (peserta didik dan guru)

4. Dukungan guru sebagai penanggung jawab laboratorium IPA di sekolah yang memadai

5. Menggunakan dan merawat alat sebaik mungkin

6. Dapat mempersiapkan proposal pengembangan kegiatan laboratorium seawal mungkin

7. Merencanakan pengadaan dan perawatan alat dan bahan laboratorium untuk memenuhi kebutuhan proses pembelajaran

8. Mengoptimalkan penggunaan laboratorium

Setiap laboratorium memiliki karakteristik yang berbedabeda dalam proses administrasi laboratorium. Tetapi secara umum, proses administrasi laboratorium meliputi prasarana laboratorium, ruangan laboratorium, fasilitas umum, alat dan bahan laboratorium, kegiatan di laboratorium, sumber daya manusia, dan keuangan.

1. Administrasi prasarana laboratorium

Prasarana laboratorium IPA di SMP antara lain gedung, ruang praktikum, ruang persiapan, ruang pengelola laboratorium, ruang penyimpanan alat dan bahan, gudang, kebun, dan kolam

2. Administrasi ruangan laboratorium

Laboratorium harus memiliki denah yang menggambarkan ruangan laboratorium. Denah berisi informasi tentang ukuran ruangan, letak setiap bagian ruangan, instalasi jaringan listrik, 
air, dan gas, dan saluran pembuangan limbah. Setiap bagian ruangan diberi keterangan berupa nama, ukuran, dan kapasitas

3. Administrasi fasilitas umum

Fasilitas umum atau dapat juga disebut dengan perlengkapan umum laboratorium merupakan alat-alat penunjang laboratorium seperti alat pemadam kebakaran, perlengkapan P3K, meja, kursi, dsb

4. Administrasi alat dan bahan laboratorium

Alat dan bahan yang dibutuhkan laboratorium tergantung dari jenis laboratoriumnya. Laboratorium IPA memiliki peralatan yang berkaitan dengan biologi, fisika, dan kimia sehingga pengelola laboratorium menatanya sesuai dengan keilmuan dan sistematis

5. Administrasi kegiatan di laboratorium

Kegiatan di laboratorium dapat dikelompokkan menjadi perawatan alat dan bahan serta kegiatan pembelajaran. Perawatan dimulai dari perencanaan, pelaksananaan, dan evaluasi. Perawatan dilakukan secara kontinu untuk menjaga alat dan bahan selalu dalam kondisi baik sehingga dapat digunakan untuk menunjang proses pembelajaran secara optimal. Sedangkan kegiatan pembelajaran, ada kalanya pembelajaran dilakukan di laboratorium karena alat dan bahan tidak memungkinkan dibawa ke kelas. Jadwal pembelajaran di laboratorium harus disusun dengan teliti agar tidak terjadi penggunaan laboratorium di jam dan hari yang sama

6. Administrasi sumber daya manusia Laboratorium IPA memiliki pengelola yang terdiri dari guru, kepala laboratorium, teknisi, dan laboran. Pengelola bertugas untuk mengatur dan merencanakan berbagai program terkait peningkatan kualitas laboratorium. Pengelola laboratorium memiliki kualifikasi dan kompetensi tertentu. Administrasi sumber daya manusia bertujuan untuk mendata kompetensi pengelola laboratorium sehingga dapat menyusun rencana untuk meningkatkan kompetensi melalui kegiatan pelatihan 
atau workshop yang ditawarkan oleh berbagai instansi terpercaya

7. Administrasi keuangan

Laboratorium memerlukan dukungan dana untuk biaya operasional. Dana ini digunakan untuk penyediaan, perawatan alat dan bahan, pengembangan kompetensi pengelola laboratorium, dan honor pengelola laboratorium. Dana dapat diperoleh dari pemerintah, masyarakat, maupun swadaya sekolah. Administrasi keuangan bertujuan untuk mengatur keuangan secara jelas dan transparan

\section{Inventarisasi Alat dan Fasilitas Laboratorium}

Inventarisasi merupakan bagian dari administrasi laboratorium. Inventarisasi merupakan kegiatan mencatat dan menyusun daftar inventaris alat dan bahan secara teratur dengan menggunakan ketentuan yang berlaku. Kegiatan inventaris merupakan kegiatan yang mutlak dilakukan dan berfungsi untuk memberikan informasi terkait alat dan bahan yang dimiliki suatu laboratorium, memudahkan penyusunan dan pengawasan terhadap peralatan laboratorium, dan menyusun perencanaan pengembangan kegiatan laboratorium sehingga hasil inventaris harus disimpan dengan aman untuk menghindari kerusakan, pencurian, penyalahgunaan, dan kebakaran. Tujuan dilakukan inventarisasi adalah:

1. Membantu dan memudahkan pengelola laboratorium serta guru mengetahui jumlah dan jenis peralatan

2. Dapat mengetahui dan menentukan kondisi alat dan bahan dalam keadaan baik atau rusak

3. Merencanakan penyediaan alat dan bahan yang diperlukan

4. Menyediakan informasi bagi pengelola dan pengguna laboratorium terkait jenis dan letak alat dan bahan tertentu 
Sistem inventarisasi laboratorium menggunakan beberapa format baku dan memiliki hierarki sebagai berikut:

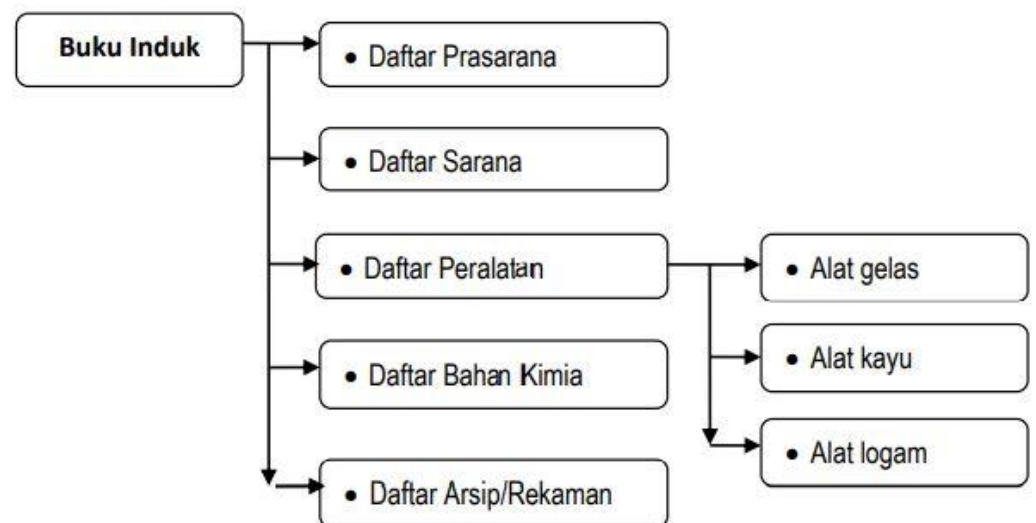

Gambar 6.1 Urutan Inventarisasi Laboratorium Sekolah Sumber : Rosada, dkk, 2017

Daftar prasarana, sarana, peralatan, dan bahan kimia berisi daftar barang-barang yang terdapat di laboratorium seperti gedung, ruangan, alat peraga, meja kursi, alat dan bahan laboratorium, dsb. Lebih lanjut akan dibahas pada subbab berikutnya. Daftar prasarana mengikuti Format A yang dapat dilihat pada Lampiran 1. Sedangkan daftar arsip atau rekaman berupa dokumen yang berisi tentang kegiatan yang dilakukan di laboratorium seperti lembar kegiatan siswa, data hasil praktikum siswa, nilai praktikum, tata tertib laboratorium, jadwal praktikum, kehadiran siswa di laboratorium, dan buku atau katalog (rekaman pemeliharaan dan perawatan alat dan bahan, penerimaan dan pengeluaran barang, formulir peminjaman dan pengembalian alat dan bahan).

Pelaksanaan inventarisasi melalui beberapa tahapan. Tahapan-tahapan tersebut antara lain:

1. Mengidentifikasi fasilitas dan peralatan laboratorium 
2. Mengelompokkan peralatan laboratorium berdasarkan sifat dan jenis

3. Memberi kode inventaris

4. Mencatat semua peralatan laboratorium kedalam buku induk dan buku golongan barang inventaris

5. Membuat laporan secara periodik tentang keadaan dan mutasi peralatan laboratorium

6. Membuat daftar rekapitulasi

Inventarisasi alat dan bahan harus diperbaharui secara kontinu dalam batas periode tertentu sehingga daftar inventaris sesuai dengan keadaan peralatan dan fasilitas laboratorium dalam periode waktu bersangkutan. Daftar inventaris sebaiknya dapat dibaca oleh pihak-pihak terkait yang memiliki kepentingan tetapi tidak dapat diubah oleh siapapun kecuali pihak yang berwenang. Daftar inventaris harus memudahkan dalam penyimpanan, pengambilan, dan pemeliharaan peralatan dan fasilitas laboratorium.

\section{E. Administrasi Stok Laboratorium}

Stok laboratorium merupakan segala fasilitas dan peralatan yang terdapat di laboratorium. Meliputi alat-alat penunjang serta alat dan bahan praktikum. Semua peralatan tersebut dicatat dengan menggunakan format tertentu dan dipisah antara alat penunjang, alat, dan bahan untuk memudahkan pengecekan.

1. Alat penunjang

Alat penunjang yang dimaksudkan adalah alat-alat yang mendukung proses praktikum maupun pembelajaran di laboratorium. Format yang digunakan disebut Format B terdiri dari kartu barang, daftar barang, daftar penerimaan atau pengeluaran barang, dan daftar permintaan atau usulan barang.

a) Kartu barang

Kartu ini digunakan untuk mencatat spesifikasi barang dan hanya digunakan untuk satu macam barang. Kartu ini disusun secara alfabetis untuk memudahkan dalam 
pencarian. Informasi yang tertulis di kartu ini antara lain: nama barang, nomor kartu, nomor induk barang, jenis barang, spesifikasi (merk, ukuran, pabrik, kode barang), lokasi penyimpanan, mutasi barang, dan riwayat barang. Format kartu barang disebut Format B1 dan dapat dilihat pada Lampiran 2.

1) Nomor kartu merupakan nomor yang diberikan pada barang dan disusun sesuai abjad

2) Nomor induk barang merupakan nomor yang tertulis pada buku induk atau daftar barang

3) Jenis barang yang dimaksudkan adalah barang tersebut merupakan barang perkakas atau perabotan

4) Spesifikasi umumnya terdapat pada katalog atau diberikan oleh pabrik pembuatnya

5) Lokasi penyimpanan merupakan tempat diletakkannya barang tersebut

6) Mutasi barang berkaitan dengan masuk dan keluarnya barang di laboratorium. Apabila barang masuk maka di kolom keterangan diisi sumber dana dan tahun pengadaan. Sedangkan apabila keluar maka di kolom keterangan diisi tempat terakhir yang dituju

7) Riwayat barang berisi tentang pelaksanaan pemeliharaan dan perawatan barang tersebut

b) Daftar barang atau buku induk

Merupakan rekapitulasi dari kartu barang. Hal-hal yang perlu diperhatikan dalam mengisi daftar barang adalah nomor kartu, nomor induk, spesifikasi barang, dan jumlah barang. Apabila suatu barang tercatat tidak memiliki jumlah, tidak boleh menghapusnya dari daftar barang atau buku induk. Hal ini bertujuan untuk memudahkan pengecekan di masa mendatang. Format ini disebut Format B2 dan dapat dilihat pada Lampiran 3.

c) Daftar penerimaan atau pengeluaran barang 
Setiap barang yang diterima atau keluar harus dicatat oleh pengelola laboratorium. Daftar ini bersifat sebagai bukti bahwa barang sudah diterima maupun keluar. Format ini disebut Format B3 dan dapat dilihat pada Lampiran 4.

d) Daftar permintaan atau usulan barang

Permintaan atau usulan barang dapat berupa perbaikan/perawatan atau pengadaan barang baru. Permintaan ini dilakukan oleh kepala laboratorium dengan seizin kepala sekolah berdasarkan analisis kebutuhan laboratorium. Saat pengusulan, spesifikasi barang merupakan hal yang penting sehingga apabila barang datang tidak sesuai dengan spesifikasi maka pemesan dapat menolak. Setiap laboratorium hendaknya memiliki katalog barang, alat, dan bahan untuk memudahkan perencanaan. Format ini disebut Format B4 dan dapat dilihat pada Lampiran 5.

2. Alat laboratorium

Alat laboratorium berkaitan dengan alat-alat yang digunakan untuk praktikum. Format yang digunakan sama dengan format alat penunjang, hanya saja mengganti nama "barang" dengan nama "alat". Jenis barang diganti dengan golongan alat yang memuat informasi tentang alat elektronik, alat optik, alat gelas, alat kayu, alat porselen, dsb. Format tersebut antara lain: kartu alat, daftar alat atau buku induk, daftar penerimaan dan pengeluaran barang, dan daftar permintaan atau usulan alat. Format ini disebut Format $\mathrm{C}$ dan dapat dilihat pada Lampiran 6.

3. Bahan laboratorium

Bahan laboratorium berkaitan dengan bahan-bahan kimia yang digunakan di laboratorium. Format yang digunakan sama dengan format alat laboratorium, hanya saja mengganti nama "alat" dengan nama "bahan kimia". Format yang digunakan adalah kartu bahan kimia, daftar bahan kimia, daftar penerimaan dan pengeluaran bahan kimia, dan daftar 
permintaan atau usulan bahan kimia. Selain itu terdapat penambahan spesifikasi seperti rumus kimia, konsentrasi, dan nama dalam bahasa Inggris. Pada tempat penyimpanan bahan kimia terdapat etiket yang berisi informasi penting tersebut sehingga etiket tidak boleh hilang. Format ini disebut Format D dan dapat dilihat pada Lampiran 7.

\section{F. Administrasi Kegiatan di Laboratorium}

Kegiatan pembelajaran dapat dilakukan di laboratorium terutama praktikum. Praktikum dapat membantu siswa dalam memahami dan menguasai konsep IPA. Kegiatan pembelajaran di laboratorium perlu direncanakan dengan baik agar dapat berlangsung secara optimal. Perencanaan meliputi kegiatan yang akan dilakukan di laboratorium, kegiatan dalam rangka peningkatan kompetensi pengelola laboratorium, dan dana operasional laboratorium. Perencanaan disusun ke dalam program kerja laboratorium. Proker ini umumnya disusun di awal tahun ajaran dengan melibatkan pengelola laboratorium dan guru IPA. Format program kerja laboratorium dapat dilihat pada Lampiran 8.

Administrasi kegiatan laboratorium yang dibahas pada subbab ini adalah administrasi kegiatan praktikum yang dilakukan siswa. Administrasi yang dimaksud meliputi jadwal praktikum, presensi kehadiran guru dan siswa, pelaksanaan praktikum termasuk tata tertib, LKS yang digunakan, panduan penyusunan laporan praktikum, dan aturan penilaian praktikum.

1. Jadwal praktikum

Waktu yang digunakan untuk praktikum umumnya sama dengan jadwal pelajaran yang sudah dibuat oleh sekolah. Apabila guru IPA akan melakukan praktikum di laboratorium maka akan melakukan koordinasi dengan laboran dan kepala laboratorium. Penyusunan jadwal praktikum dapat mengikuti format berikut ini. 


\section{Jadwal Pemakaian Laboratorium IPA}

Tahun Ajaran ......

\begin{tabular}{|l|c|l|l|l|l|}
\hline No & $\begin{array}{c}\text { Nama } \\
\text { Guru IPA }\end{array}$ & Hari & Kelas & Jam & Keterangan \\
\hline & & & & & \\
\hline & & & & & \\
\hline & & & & & \\
\hline & & & & & \\
\hline
\end{tabular}

Sidoarjo, ............. 2020

Mengetahui,

Kepala Sekolah

Kepala Laboratorium

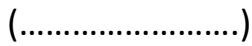

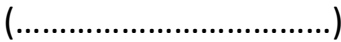

2. Presensi kehadiran guru dan siswa

Presensi perlu dilakukan sebagai bukti telah terjadi kegiatan praktikum di laboratorium. Pada umumnya di SMP, tidak terdapat presensi khusus untuk guru dan siswa karena telah menjadi satu dengan presensi jurnal kelas. Akan tetapi, kegiatan praktikum dapat diketahui melalui jurnal kegiatan praktikum yang diisi guru setelah selesai melakukan praktikum. Contoh jurnal kegiatan praktikum sebagai berikut. 


\section{Jurnal Kegiatan Praktikum di Laboratorium}

\begin{tabular}{|l|l|l|l|l|l|l|l|}
\hline No & Hari/tgl & $\begin{array}{c}\text { Nama } \\
\text { Guru } \\
\text { IPA }\end{array}$ & $\begin{array}{c}\text { Judul } \\
\text { Praktikum }\end{array}$ & Kelas/Jam & $\begin{array}{c}\text { Alat } \\
\text { dan } \\
\text { Bahan }\end{array}$ & $\begin{array}{c}\text { Paraf } \\
\text { Guru } \\
\text { IPA }\end{array}$ & Keterangan \\
\hline & & & & & & & \\
\hline & & & & & & & \\
\hline & & & & & & & \\
\hline & & & & & & & \\
\hline & & & & & & & \\
\hline & & & & & & & \\
\hline & & & & & & & \\
\hline & & & & & & & \\
\hline & & & & & & & \\
\hline
\end{tabular}

Sidoarjo,

2020

Mengetahui,

Kepala Sekolah

Kepala Laboratorium

$(\ldots \ldots \ldots \ldots \ldots \ldots \ldots \ldots . . .$.

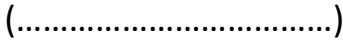

3. Pelaksanaan praktikum

Kegiatan praktikum dilakukan sesuai dengan jadwal yang telah ditentukan, menggunakan alat dan bahan yang telah disiapkan, mengerjakan praktikum sesuai LKS, dan menaati tata tertib di laboratorium. Sebagai pengguna laboratorium baik guru maupun siswa harus mengikuti tata tertib yang berlaku untuk menjaga lingkungan laboratorium tetap kondusif. Terdapat pula sanksi yang diberikan apabila pengguna laboratorium melanggar tata tertib. Setiap sekolah memiliki perbedaan dalam menyusun tata tertib dan sanksi akan tetapi memiliki garis besar yang sama. Contoh tata tertib dan sanksi dapat dilihat pada Lampiran 9 dan 10.

4. Lembar kegiatan siswa (LKS)

Lembar kegiatan siswa disusun sebagai petunjuk dalam melakukan praktikum. LKS disediakan oleh guru pengampu 
dan disusun berdasarkan buku siswa elektronik (BSE) atau referensi lain yang digunakan guru.

5. Panduan penyusunan laporan praktikum

Tidak ada panduan baku untuk penyusunan laporan praktikum karena bergantung dengan guru pengampu. Ada kalanya antar guru IPA memiliki format yang berbeda tetapi memiliki garis besar yang sama. Panduan penyusunan laporan dapat diberikan secara terpisah saat pelaksanaan praktikum atau dijadikan satu dengan LKS. Panduan ini berfungsi membantu siswa dalam menyusun laporan praktikum. Contohnya dapat dilihat pada Lampiran 11.

6. Aturan penilaian praktikum

Praktikum juga perlu dilakukan penilaian. Penilaian praktikum berfungsi sebagai umpan balik terhadap kinerja siswa setelah melakukan praktikum. Untuk penilaian praktikum tidak ada ketentuan khusus karena pada umumnya masing-masing guru IPA memiliki referensi tersendiri dalam melakukan penilaian. Contoh penilaian praktikum sebagai berikut.

$$
\begin{aligned}
N A=\frac{(1 \times P)+(1 \times K)+(1 \times L S)+(3 x L P)+(4 x S H)}{10} \\
\text { dengan : } \mathrm{P}=\text { pralab } \\
\mathrm{K}=\text { kehadiran } \\
\mathrm{LS}=\text { laporan sementara } \\
\mathrm{LP}=\text { laporan praktikum } \\
\mathrm{SH}=\text { seminar hasil }
\end{aligned}
$$

\section{G. Administrasi Peminjaman Alat dan Bahan}

Kegiatan praktikum membutuhkan alat dan bahan yang harus dipersiapkan terlebih dahulu sebelum praktikum. Peminjaman alat dan bahan perlu dicatat untuk mengetahui waktu penggunaan, pengguna alat dan bahan, jumlah yang dipinjam, serta penanggung jawab alat dan bahan setelah dipinjam. Hal ini bertujuan untuk menghindari tindakan tidak bertanggung jawab seperti pencurian dan kerusakan alat yang disebabkan kecerobohan pengguna. Selain mengisi format peminjaman alat 
dan bahan, peminjam akan diminta meninggalkan kartu identitas sebagai jaminan. Di tingkat SMP, yang bertindak sebagai peminjam adalah guru IPA. Guru IPA mengajukan peminjaman alat dan bahan ke kepala laboratorium kemudian laboran menyiapkannya. Berikut ini beberapa contoh format peminjaman alat dan bahan labortorium.

Contoh 1

\section{Daftar Persiapan Kegiatan Praktikum Laboratorium IPA}

Judul Percobaan :

Kelas/Semester

\begin{tabular}{|l|c|l|l|}
\hline No & $\begin{array}{c}\text { Nama Alat dan Bahan } \\
\text { Kimia }\end{array}$ & Jumlah & Keterangan \\
\hline & & & \\
\hline & & & \\
\hline & & & \\
\hline & & & \\
\hline & & & \\
\hline & & & \\
\hline & & & \\
\hline & & & \\
\hline & & & \\
\hline
\end{tabular}

Sidoarjo, 2020

Menyetujui,

Kepala Laboratorium

Guru IPA

$($..........................)

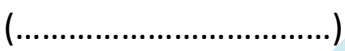


Contoh 2

Daftar Peminjaman Alat dan Bahan

Laboratorium IPA

\begin{tabular}{|l|l|l|l|l|l|l|}
\hline No & Hari/tgI & $\begin{array}{c}\text { Nama } \\
\text { Guru } \\
\text { IPA }\end{array}$ & $\begin{array}{c}\text { Alat dan } \\
\text { Bahan }\end{array}$ & Jumlah & Keterangan & $\begin{array}{c}\text { Paraf } \\
\text { Petugas }\end{array}$ \\
\hline & & & & & & \\
\hline & & & & & & \\
\hline & & & & & & \\
\hline & & & & & & \\
\hline & & & & & & \\
\hline & & & & & & \\
\hline & & & & & & \\
\hline & & & & & & \\
\hline & & & & & & \\
\hline & & & & & & \\
\hline & & & & & & \\
\hline & & & & & & \\
\hline & & & & & & \\
\hline & & & & & & \\
\hline
\end{tabular}


Contoh 3

Buku Peminjaman Alat dan Bahan Laboratorium IPA

\begin{tabular}{|c|c|c|c|c|c|c|c|c|c|c|}
\hline \multirow[b]{2}{*}{$\begin{array}{l}N \\
\mathrm{O}\end{array}$} & \multirow{2}{*}{$\begin{array}{c}\text { Hari/tg } \\
\text { I }\end{array}$} & \multirow[b]{2}{*}{$\begin{array}{l}\mathrm{Ja} \\
\mathrm{m}\end{array}$} & \multirow{2}{*}{$\begin{array}{c}\text { Nama } \\
\text { Peminja } \\
\text { m }\end{array}$} & \multirow{2}{*}{$\begin{array}{c}\text { Judul } \\
\text { Praktiku } \\
\text { m }\end{array}$} & \multicolumn{2}{|c|}{ Pelaksanaan } & \multirow{2}{*}{$\begin{array}{c}\text { Alat dan } \\
\text { bahan yang } \\
\text { dipinjam }\end{array}$} & \multirow[b]{2}{*}{ Tgl kembali } & \multirow[b]{2}{*}{$\begin{array}{c}\text { TTD } \\
\text { peminjam }\end{array}$} & \multirow[b]{2}{*}{$\begin{array}{c}\text { TTD } \\
\text { petugas }\end{array}$} \\
\hline & & & & & $\begin{array}{l}\text { Dem } \\
\text { o }\end{array}$ & $\begin{array}{l}\text { Praktiku } \\
\mathrm{m}\end{array}$ & & & & \\
\hline & & & & & & & & & & \\
\hline & & & & & & & & & & \\
\hline & & & & & & & & & & \\
\hline & & & & & & & & & & \\
\hline & & & & & & & & & & \\
\hline & & & & & & & & & & \\
\hline & & & & & & & & & & \\
\hline & & & & & & & & & & \\
\hline
\end{tabular}

Sidoarjo, 2020

Mengetahui, Kepala Sekolah

Kepala Laboratorium

(.........................)

$($ (........................................ 


\section{H. Administrasi Pengkodean Alat dan Bahan}

Pengkodean alat dan bahan merupakan pemberian label kepada setiap alat dan bahan di laboratorium untuk memudahkan proses identifikasi sebelum digunakan. Label berisi informasi tentang nama suatu alat atau bahan beserta informasi-informasi penting dan singkat yang dibutuhkan. Label yang diberikan pada alat dan bahan, umumnya berisi informasi tanggal pembuatan larutan atau pengadaan barang, ukuran label disesuaikan dengan ukuran alat atau tempat penyimpanan bahan kimia, ditempel pada alat menggunakan selotip agar tidak mudah rusak dan lepas.

Contoh label pada alat praktikum

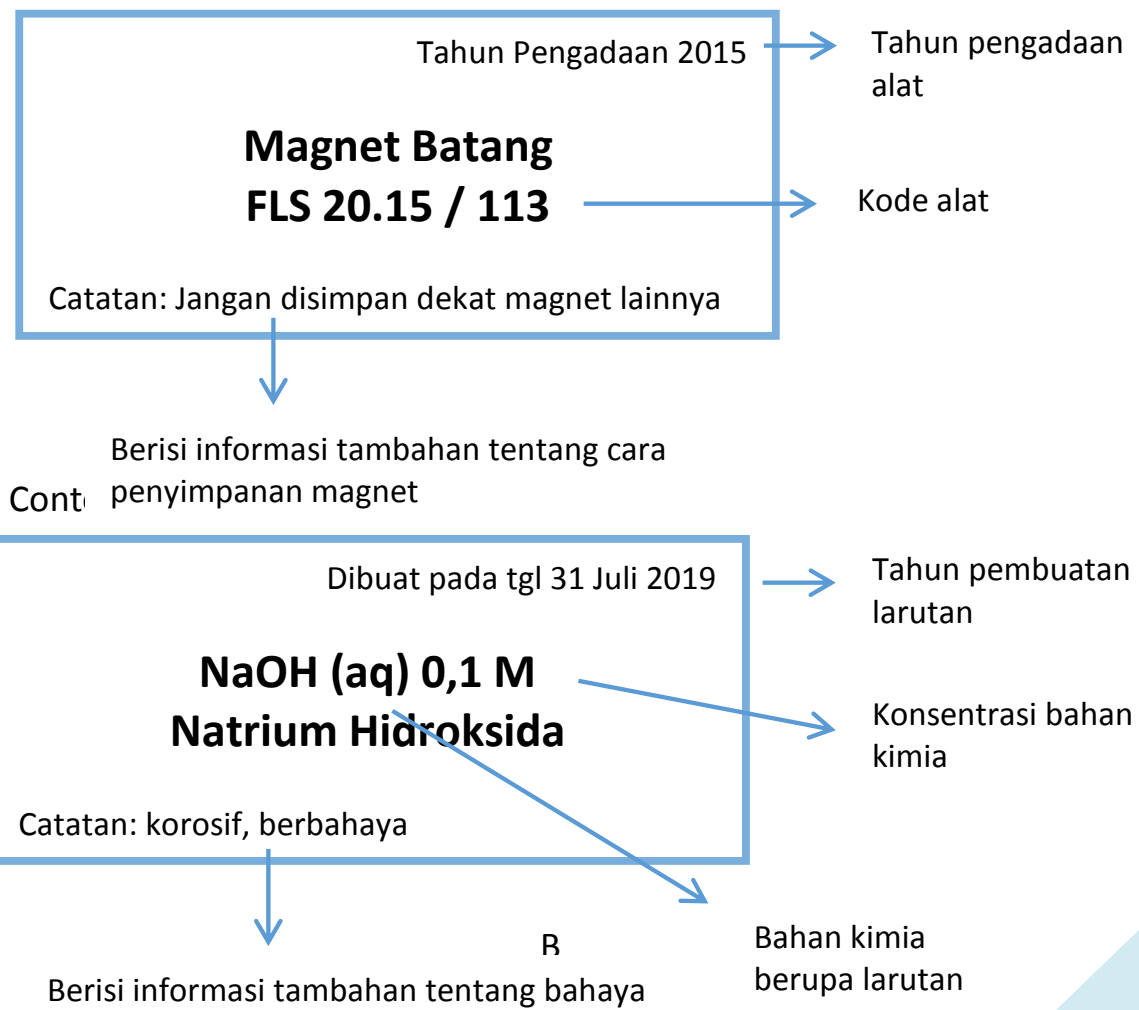

bahan kimia tersebut 


\section{BAB VII \\ PENGAMANAN, PERAWATAN, DAN PENGAWASAN}

\section{A. Sub Capaian Pembelajaran Matakuliah}

1. Mahasiswa mampu mendeskripsikan cara Menjaga keselamamatan dilaboratorium

2. Mahasiswa mampu menganalisis Kecelakaan yang mungkin terjadi dilaboratorium

\section{B. Pengamanan}

Keamanan kerja merupakan bagian penting dalam pelaksanaan praktikum di laboratorium. Semakin tersedianya fasilitas laboratorium dan sikap mawas diri dari pengguna laboratorium dapat meminimalkan resiko kecelakaan kerja di laboratorium. Beberapa penyebab terjadinya kecelakaan di laboratorium adalah kelalaian atau kecerobohan pengguna laboratorium, kurang memahami sifat bahan kimia yang digunakan, kurang memahami instrumen dan bahayanya, tidak mengikuti petunjuk ataupun arahan, dan lemahnya pengawasan dari pengelola laboratorium terutama laboran atau asistensi. Oleh karena itu, perlu dilakukan upaya pencegahan dengan memberikan pengetahuan pentingnya keselamatan kerja sebagai bentuk pengamanan saat melakukan praktikum. Informasi keselamatan kerja dapat disampaikan sebelum, saat, atau setelah praktikum. Pembahasan lebih lanjut tentang keselamatan kerja di laboratorium dibahas pada bab IX.

\section{Perawatan}

Bagian terpenting lainnya dalam pelaksanaan praktikum di laboratorium adalah perawatan dan perbaikan alat dan bahan praktikum. Peralatan praktikum harus dilakukan perawatan secara kontinu agar selalu dalam kondisi baik sehingga dapat digunakan sewaktu-waktu. Perawatan peralatan praktikum merupakan suatu kegiatan yang harus direncanakan, dilaksanakan, dan dievaluasi dengan baik dan benar agar peralatan dapat digunakan secara optimal dalam mendukung proses pembelajaran. 
Perawatan peralatan laboratorium merupakan usaha pencegahan agar alat tidak rusak, tetap terjaga dalam kondisi yang baik, dan siap digunakan kapanpun. Sedangkan perbaikan peralatan laboratorium merupakan usaha memperbaiki kembali alat-alat praktikum yang mengalami kerusakan atau tidak berfungsi sehingga dapat digunakan kembali saat melakukan praktikum. Perawatan dan perbaikan peralatan laboratorium merupakan bagian dari pengelolaan laboratorium yang bertujuan menjaga alat-alat praktikum berfungsi dengan baik dan maksimal sesuai dengan batas usia pemakaiannya. Kegiatan yang dilakukan antara lain: membersihkan alat, memperbaiki dan mengganti bagian yang rusak, menyimpan alat sesuai daftar inventaris, dan mengecek ketersediaan alat. Perawatan harus selalu dicatat untuk mengetahui riwayat alat.

1. Jenis perawatan

Jenis perawatan dikelompokkan menjadi dua, yaitu perawatan terencana dan tidak terencana.

a) Perawatan terencana

Perawatan terencana merupakan perawatan yang terprogram, terjadwal, terorganisir, terdapat anggaran, memiliki monev, dan sesuai dengan rencana. Tujuan dari perawatan terencana adalah mencegah kerusakan alat. Perawatan terencana terdiri dari dua jenis yaitu perawatan preventif dan korektif.

1) Perawatan preventif

Perawatan ini bersifat untuk mencegah alat-alat mengalami kerusakan. Perawatan preventif dilakukan melalui perencanaan, pengorganisasian, pelaksanaan, dan monev. Perawatan preventif dikenal juga dengan istilah servis, yaitu melakukan pemeriksaan sesuai dengan petunjuk. Misalnya pembersihan lensa-lensa pada mikrosko dan pelumasan alat-alat logam seperti engsel pada mikroskop yang bertujuan untuk menaikkan dan menurunkan tubus

2) Perawatan korektif

Perawatan korektif bersifat perbaikan dan bertujuan untuk mengembalikan fungsi alat ke kondisi standar 
sehingga dapat berfungsi dengan normal. Misalnya memperbaiki alkohol pada pipa kapiler yang terputusterputus

b) Perawatan tidak terencana

Perawatan yang dilakukan untuk memperbaiki alat-alat yang mengalami kerusakan tanpa diperkirakan sebelumnya. Perawatan dilakukan secara tiba-tiba karena alat akan segera digunakan. Ciri dari perawatan tidak terencana adalah alat digunakan sampai rusak setelah rusak dilakukan perbaikan dengan cara "penggantian". Perawatan ini tidak direncanakan dan tidak dijadwalkan sehingga dapat juga disebut perawatan darurat.

2. Objek perawatan laboratorium

Objek laboratorium yang memerlukan perawatan antara lain:

a) Ruangan laboratorium meliputi kebersihan lantai, ventilasi, lampu atau penerangan, saluran sanitasi

b) Perabotan laboratorium meliputi meja percobaan, kursi guru dan siswa, almari, rak penyimpanan

c) Perlengkapan dokumentasi dan administrasi laboratorium seperti komputer (termasuk hardware dan software) dan buku pencatatan

d) Jaringan listrik meliputi sekering, stop kontak, lampu

e) Peralatan praktikum

f) Specimen dan bahan-bahan praktikum

g) Instrumen dan alat-alat ukur

3. Tenaga perawatan

Laboran atau teknisi memiliki tanggung jawab dalam perawatan peralatan laboratorium. Salah satu tugas laboran adalah melakukan perawatan yang meliputi kegiatan menjaga, menyimpan, membersihkan, merawat, menyetel ulang alat, melakukan kalibrasi, bahkan melakukan perbaikan dan penggantian terhadap komponen alat yang rusak. Untuk perawatan alat khusus yang telah mengalami kerusakan parah dapat menggunakan teknisi ahli dari luar. Misalnya memperbaiki alat optik, alat elektronik yang memiliki komponen rumit. Untuk perawatan dalam skala ringan dan mudah dapat melibatkan 
praktikan dengan cara membersihkan alat setelah digunakan, meletakkan kembali ke tempat penyimpanan, menjaga kebersihan ruang laboratorium, serta mematuhi tata tertib di laboratorium untuk menghindari kecelakaan kerja.

4. Biaya perawatan

Perawatan peralatan laboratorium membutuhkan dana operasional dalam pelaksanaannya sehingga biaya perawatan harus dimasukkan ke dalam program kerja laboratorium. Biaya perawatan yang dibutuhkan antara lain:

a) Pembelian bahan-bahan untuk perawatan seperti sabun, cat, kain lap, karbol, bahan pengawet, perekat, pencegah jamur, dsb

b) Pembelian peralatan perawatan seperti sapu, sikat, gunting, obeng, tang, sulak, dsb

c) Pembelian suku cadang seperti kran air, kabel, mouse computer, lensa optik, dsb

d) Honor tenaga perawatan terutama ketika mendatangkan tenaga ahli dari luar

5. Bahan perawatan

Bahan perawatan merupakan bahan-bahan yang digunakan untuk melakukan perawatan seluruh peralatan praktikum. Bahan perawatan harus dalam jumlah yang memadai. Bahan yang digunakan untuk perawatan peralatan laboratorium antara lain:

a) Bahan untuk pekerjaan kebersihan seperti sabun, karbol, kantong plastik, kain lap, tisu, dan pembersih lainnya

b) Bahan untuk pemeliharaan seperti minyak pelumas, bahan pengawet, pembungkus, bahan pelapis, bahan pelindung, pupuk tanaman, pembasmi serangga, makanan hewan di laboratorium biologi

c) Suku cadang seperti kabel, mur baut, kran air, kawat, aluminium, benang

6. Peralatan perawatan

Peralatan perawatan sangat diperlukan dalam rangka merawat alat-alat praktikum ketika mengalami kerusakan. Apabila 
laboratorium memiliki peralatan yang lengkap akan dapat mendukung program perawatan laboratorium tersebut. Peralatan yang dimiliki laboratorium hendaknya disesuaikan dengan fasilitas yang dirawat dan jenis kegiatan perawatan. Peralatan perawatan yang bersifat umum, sederhana, dan sering digunakan dalam kegiatan perawatan hendaknya dimiliki oleh laboratorium, misalnya obeng, tang, gunting. Peralatan perawatan antara lain:

a) Peralatan pemeliharaan, misalnya alat pelumas, alat pelapis

b) Peralatan pemeriksaan, misalnya instrumen pengukuran

c) Peralatan penyimpanan, misalnya rak, almari

d) Peralatan perbaikan

e) Peralatan penyetelan kembali

7. Cara perawatan

Cara melakukan perawatan perlu diperhatikan dan tidak boleh dilakukan secara sembarangan untuk menghindari hal-hal yang tidak diinginkan selama pembersihan dan perawatan. Cara merawat peralatan laboratorium antara lain:

a) Merawat peralatan secara umum

Peralatan setelah dibersihkan, harus dalam keadaan kering sebelum disimpan dan digunakan. Untuk membersihkannya dapat menggunakan larutan pembersih asam kromat. Hindari menyimpan alat dalam keadaan basah karena dapat menyebabkan korosi atau karat terutama pada peralatan yang terbuat dari besi

b) Membersihkan gelas laboratorium

Gelas laboratorium merupakan tempat yang digunakan untuk melarutkan bahan kimia. Cara merawatnya dengan menggunakan detergen khusus. Detergen khusus yang digunakan pada saat dilarutkan tidak boleh melebihi $20 \%$ untuk menghindari reaksi dalam jangka panjang. Setelah dibersihkan, gelas harus segeran dikeringkan untuk menghindari terjadinya pengerasan residu

c) Merawat timbangan laboratorium

Ada kalanya timbangan digunakan untuk mengukur takaran bahan kimia tertentu sehingga harus segera dibersihkan 
untuk menghindari menempelnya bahan kimia pada timbangan. Apabila terdapat bahan kimia yang menempel di timbangan, cara merawatnya dengan menggunakan sikat, kain halus, atau tisu. Kemudian mengangkat piringan timbangan dan membersihkannya dengan deterjen khusus. Setelah dibersihkan timbangan diperiksa kembali untuk memastikan bahan kimia yang menempel telah hilang. Simpanlah timbangan ke almari penyimpanan dalam keadaan kering

d) Membersihkan dengan cara khusus

Terdapat beberapa peralatan yang memerlukan cara khusus dalam perawatannya terutama untuk alat-alat yang terkena noda berbahaya sehingga dapat mengakibatkan kerusakan. Beberapa noda tersebut antara lain:

1) Noda permanganat

Alat dibersihkan menggunakan larutan yang terbuat dari campuran asam sulfat dengan takaran $3 \%$ dan hydrogen peroksida dengan takaran 3\%

2) Noda besi

Alat dibersihkan dengan larutan $\mathrm{HCL} 50 \%$

3) Noda lemak

Alat dibersihkan menggunakan larutan asam kromat yaitu larutan kalium dikromat di dalam asam sulfat yang pekat

4) Bahan mengandung kontaminasi bakteri tertentu

Alat harus direndam dalam cairan desinfektan atau diuap (steam)

8. Waktu perawatan

Waktu perawatan dilihat berdasarkan waktu yang dapat digunakan atau disepakati oleh pihak-pihak yang terlibat dalam kegiatan perawatan secara efektif dan efisien. Jadwal pelaksanaan perawatan dapat ditetapkan berdasarkan:

a) Pengalaman masa lalu dalam jenis perawatan yang sama

Apabila ditemukan masalah yang sama, perawatan dapat dilakukan seminimal dan seekonomis mungkin tanpa mengakibatkan kerusakan lebih lanjut pada alat. Bagi 
laboran yang memiliki banyak pengalaman dalam kegiatan perawatan akan memiliki banyak informasi yang bermanfaat dalam penyusunan jadwal perawatan

b) Beban pemakaian atau penggunaan peralatan laboratorium Untuk peralatan yang sering digunakan akan menyebabkan alat mudah kotor dan rusak sehingga harus sering dibersihkan dan dilakukan perawatan. Artinya, jadwal perawatan memiliki frekuensi yang lebih tinggi dibandingkan alat yang jarang digunakan

c) Rekomendasi dari pabrik pembuat alat yang digunakan laboratorium

Peralatan laboratorium yang dibeli dari pabrik akan dilengkapi dengan buku manual yang berisi petunjuk pemakaian, cara merawat, dan waktu perawatan. Hal ini bermanfaat dalam penyusunan jadwal perawatan

\section{Pengawasan}

Pengawasan merupakan upaya yang dilakukan oleh atasan dengan tujuan memantau kegiatan yang telah direncanakan dapat terlaksana dengan baik. Upaya pengawasan memiliki beberapa bentuk diantaranya adalah monitoring dan evaluasi atau disingkat monev. Monev berlaku secara keseluruhan terutama terhadap pengelolaan laboratorium.

1. Monitoring pengelolaan laboratorium

Monitoring merupakan kegiatan pemantauan perkembangan pengelolaan laboratorium yang bertujuan untuk mengetahui kesesuaian antara rencana dengan pelaksanaan kegiatan, kendala dan hambatan selama pengelolaan laboratorium, dan upaya-upaya yang telah dan akan dilakukan dalam mengatasi kendala dan hambatan yang muncul. Monitoring berpusat kepada pemantauan dan pengontrolan selama kegiatan pengelolaan laboratorium berjalan. Fokus monitoring antara lain: 1) program kerja laboratorium; 2) proses manajerial laboratorium; 3) peran serta wali murid dan komite sekolah; dan 4) aspek-aspek lain terkait pengelolaan dan pemanfaatan laboratorium. Monitoring dapat dilakukan secara internal 
maupun eksternal. Secara internal dilakukan oleh pihak sekolah dengan melibatkan pengelola laboratorium dan dilakukan lebih dari sekali dalam setahun. Secara eksternal dapat dilakukan oleh dinas pendidikan sekali dalam setahun.

2. Evaluasi pengelolaan laboratorium

Evaluasi merupakan kegiatan untuk mengetahui tingkat keberhasilan yang dilakukan oleh pengelola laboratorium. Tujuan utama dilakukan evaluasi antara lain: 1) mengetahui tingkat keterlaksanaan program pengelolaan laboratorium; 2) mengetahui keberhasilan suatu program; 3) memperoleh masukan dan saran perbaikan untuk program kerja di tahun berikutnya; 4) mengetahui kendala dan hambatan selama program berjalan; 5) pembinaan bagi pengelola laboratorium untuk meningkatkan kinerjanya. Evaluasi dilakukan di akhir program kerja. Bahan evaluasi meliputi semua kegiatan yang tertuang dalam program kerja laboratorium, diantaranya aspekaspek pembelajaran yang menggunakan laboratorium, pelaksanaan dan pengembangan proses pembelajaran di laboratorium, pengembangan sarana prasarana laboratorium, peningkatan kompetensi pengelola laboratorium, sumber dana untuk kegiatan laboratorium, aspek kegiatan penelitian, dan aspek kegiatan ekstrakurikuler yang melibatkan laboratorium. Sumber data untuk evaluasi adalah pengelola dan pengguna laboratorium yang meliputi kepala sekolah, kepala laboratorium, laboran atau teknisi, guru IPA, siswa, dan komite sekolah.

3. Pelaksana monitoring dan evaluasi

Pelaksana monev dapat dikelompokkan menjadi:

a) Tim monev internal

Tim monev internal dibentuk oleh sekolah. Umumnya anggota tim dipilih berdasarkan pertimbangan tertentu seperti memiliki kompetensi dalam pengelolaan laboratorium, memiliki pengalaman menjadi tim monev laboratorium, dan independen. Evaluasi dilakukan di akhir program kerja dengan indikator-indikator penilaian disesuaikan program kerja.

b) Tim monev eksternal 
Tim monev eksternal, biasanya dibentuk oleh dinas pendidikan. Masukan yang diberikan, diharapkan dapat lebih memperbaiki dan meningkatkan kinerja pengelola laboratorium karena tim monev eksternal memiliki pengalaman dan pandangan tentang laboratorium sekolah dari berbagai aspek.

c) Laporan monev

Laporan monev perlu disusun untuk mengetahui hasil pengelolaan laboratorium secara menyeluruh. Hasil laporan monev dapat digunakan sebagai pertimbangan dalam menyusun program kerja pada tahun berikutnya, menghindari kesalahan yang sama, dan mengidentifikasi masalah-masalah yang muncul. 


\section{BAB VIII \\ KESELAMATAN KERJA DI LABORATORIUM}

\section{A. Menjaga Keselamatan di Laboratorium}

Laboratorium IPA merupakan tempat melakukan praktikum IPA yang melibatkan alat dan bahan serta tak jarang terjadi kecelakaan yang berdampak kepada pengguna dan fasilitas laboratorium. Sehingga diperlukan pemahaman dan kesadaran tentang keamanan, keselamatan, dan bahaya kerja saat melakukan praktikum. Kecelakaan kerja dapat dihindari apabila pengguna laboratorium terutama praktikan mengikuti prosedur kerja dan tata tertib yang berlaku di laboratorium karena ada kalanya kecelakaan di laboratorium disebabkan oleh kelalaian atau kecerobohan praktikan.

Pengelola dan pengguna laboratorium akan selalu dihadapkan pada bahaya-bahaya pada saat melakukan praktikum di laboratorium. Secara garis besar, bahaya yang dihadapi di laboratorium dapat dikelompokkan menjadi bahaya kebakaran yang disebabkan oleh bahan yang mudah meledak atau konsleting arus listrik, bahan beracun atau korosif, bahaya radiasi, luka bakar, tersengat arus listrik, luka sayat akibat benda tajam atau gelas yang pecah, dan bahaya infeksi dari kuman, virus, bakteri, ataupun parasit. Umumnya, bahaya-bahaya tersebut dapat dihindari dengan cara membuat tata tertib dan pemberlakuan sanksi bagi yang melanggar, memberikan penjelasan kepada praktikan terkait cara menggunakan alat dan bahan yang benar, penerapan disiplin kerja dengan ketat. Beberapa kecelakaan yang pernah terjadi di laboratorium hendaknya dijadikan sebagai pelajaran agar tidak terulang kembali.

Keselamatan kerja berlaku untuk semua komponen yang berada di laboratorium. Keselamatan kerja dibagi menjadi:

1. Keselamatan alat

Alat perlu dijaga keselamatannya agar tidak mudah rusak dan dapat digunakan sesuai masa maksimal penggunaannya. Keselamatan alat berkaitan dengan penataan dan penyimpanan. Hal-hal yang dapat dilakukan berkaitan dengan keselamatan alat antara lain: selalu meletakkan dan menyimpan alat di tempatnya, penyimpanan alat berdasarkan jenisnya, selalu 
berhati-hati ketika mengambil dan mengembalikan ke tempatnya, berhati-hati dan mengikuti petunjuk penggunaan ketika melakukan praktikum, segera melapor ke guru atau laboran ketika mengalami kendala saat mengoperasikan alat, serta membersihkan alat setelah digunakan praktikum.

2. Keselamatan bahan

Semua bahan kimia harus tersimpan dalam tempat penyimpanan yang sesuai dan tahan lama. Sebaiknya disimpan di tempat-tempat yang kecil dan cukup untuk pemakaian seharihari. Tempat penyimpanan untuk jangka panjang harus khusus, misalnya gudang bahan kimia. Setiap bahan kimia harus dilakukan pengecekan secara berkala untuk menentukan kelayakan penggunaan bahan kimia, mengetahui masa kadaluwarsa bahan kimia, dan memperbaiki label yang rusak. Bahan-bahan kimia yang sudah tidak dapat digunakan harus segera dimusnahkan secara kimia.

Terdapat beberapa simbol yang berfungsi menunjukkan bahaya bahan kimia apabila terkena tubuh atau mencemari lingkungan. Simbol ini akan dilekatkan pada tempat penyimpanan bahan kimia tersebut sehingga praktikan dapat meningkatkan kewaspadaan ketika bekerja dengan bahan kimia tersebut. Beberapa simbol dapat dilihat pada Tabel 9.1.

Tabel 9.1 Simbol bahaya pada bahan laboratorium

\begin{tabular}{|l|l|l|l|}
\hline No & Simbol & \multicolumn{1}{|c|}{ Nama } & \multicolumn{1}{|c|}{ Keterangan } \\
\hline 1 & & & \\
\hline 2 & &
\end{tabular}




\begin{tabular}{|l|l|l|l|}
\hline No & \multicolumn{1}{|c|}{ Nama } & \multicolumn{1}{c|}{ Keterangan } \\
\hline 3 & Corrosive & $\begin{array}{l}\text { Bahan dapat merusak } \\
\text { jaringan hidup }\end{array}$ \\
\hline 4 & Irritant & $\begin{array}{l}\text { Sedikit saja masuk ke } \\
\text { tubuh dapat } \\
\text { membakar kulit, } \\
\text { selaput lendir atau } \\
\text { sistem pernapasan }\end{array}$ \\
\hline 5 & Toxic & $\begin{array}{l}\text { Sedikit saja masuk ke } \\
\text { tubuh dapat sakit } \\
\text { keras bahkan } \\
\text { kematian }\end{array}$ \\
\hline
\end{tabular}




\begin{tabular}{|l|l|l|l|}
\hline No & Simbol & \multicolumn{1}{|c|}{ Nama } & \multicolumn{1}{c|}{ Keterangan } \\
\hline 9 & & Biohazard & $\begin{array}{l}\text { Bahan-bahan yang } \\
\text { berasal dari } \\
\text { mikroorganisme yang } \\
\text { dapat } \\
\text { membahayakan } \\
\text { kesehatan }\end{array}$ \\
\hline 10 & & $\begin{array}{l}\text { Dangerous } \\
\text { for } \\
\text { environment }\end{array}$ & $\begin{array}{l}\text { Bahahah yang } \\
\text { berbahaya bagi } \\
\text { lingkungan }\end{array}$ \\
\hline
\end{tabular}

Hal-hal yang perlu diperhatikan dalam upaya menjaga keselamatan bahan antara lain: selalu membaca petunjuk penggunaan bahan, mengambil bahan sesuai konsentrasi yang dibutuhkan dengan alat yang sesuai, segera mengembalikan bahan ke rak penyimpanan, tidak merusak label atau etiket yang menempel pada wadah, tidak mencampur bahan tanpa pengawasan guru atau laboran, segera membuang limbah bahan kimia pada saluran pembuangan limbah.

3. Keselamatan pengguna

Pengguna laboratorium meliputi orang-orang yang berada di dalam laboratorium dalam rangka melakukan praktikum. Pengguna laboratorium meliputi praktikan, guru, laboran, kepala laboratorium, ataupun peneliti. Agar terhindar dari bahaya kecelakaan, maka keamanan, keselamatan, dan kesehatan pengguna harus dijaga. Perlengkapan keselamatan kerja harus tersedia sebagai upaya melindungi pengguna laboratorium dari kecelakaan. Perlengkapan keselamatan dibagi kedalam dua kelompok, yaitu: perlengkapan untuk melindungi diri dari alatalat laboratorium dalam kasus darurat dan perlengkapan yang digunakan sehari-hari untuk mengantisipasi bahan-bahan yang berbahaya. Beberapa perlengkapan yang dapat digunakan di laboratorium antara lain:

1. Jas laboratorium untuk mencegah kotornya baju 
2. Pelindung tangan untuk melindungi dari panas, bahan kimia, atau bahaya lain

3. Pelindung mata untuk melindungi mata dari percikan bahan kimia

4. Sepatu pengaman untuk melindungi kaki dari pecahan kaca atau tertimpa benda berat

5. Layar pelindung untuk melindungi dari ledakan bahan kimia Hal utama yang perlu diperhatikan dalam menjaga keselamatan pengguna adalah sikap hati-hati untuk meminimalkan kecerobohan atau kelalaian yang sering dilakukan saat melakukan praktikum. Selain itu, keselamatan pengguna dapat diupayakan melalui: selalu membaca petunjuk praktikum dengan benar dan teliti; tidak bersenda gurau dengan teman ketika melakukan praktikum; selalu menggunakan alat pelindung diri seperti masker, sarung tangan, jas laboratorium, sepatu pengaman, menaati tata tertib penggunaan laboratorium; serta tidak segan untuk bertanya kepada guru atau laboran apabila mengalami kesulitan saat melakukan praktikum.

\section{B. Kecelakaan yang Mungkin Terjadi di Laboratorium}

Seperti yang sudah dijelaskan pada subbab sebelumnya, kecelakaan di laboratorium dapat terjadi akibat kelalaian praktikan dalam menjaga keselamatan kerja atau tidak berfungsinya alat praktikum. Kecelakaan dapat diartikan sebagai kejadian di luar kemampuan dan prediksi manusia, terjadi secara tiba-tiba, dan dapat menimbulkan kerusakan baik secara fisik, psikis bahkan kematian. Walaupun kecelakaan selalu identik dengan keadaan berbahaya, hal ini tidak menyebabkan ketakutan untuk beraktivitas di laboratorium. Penyebab terjadinya kecelakaan di laboratorium antara lain:

1. Kurangnya pengetahuan dan tidak memahami karakteristik peralatan dan bahan-bahan yang digunakan di laboratorium

2. Tidak jelasnya petunjuk kegiatan praktikum

3. Kurangnya pengawasan ketika praktikan melakukan praktikum

4. Tidak adanya pembimbingan dari laboran atau guru ketika siswa melakukan praktikum 
5. Tidak tersedianya atau kurangnya perlengkapan pengamanan dan perlindungan diri

6. Tidak menaati tata tertib laboratorium yang berlaku

7. Tidak menggunakan alat perlindungan diri

8. Tidak berhati-hati saat melakukan praktikum

9. Tidak mengikuti petunjuk kerja laboratorium

Kecelakaan yang terjadi di laboratorium dapat mengakibatkan luka bakar, luka karena benda tajam atau benda tumpul, cedera mata, keracunan, rusaknya fasilitas laboratorium, dan rusaknya sampel percobaan milik peneliti lain. Untuk mengatasi kecelakaan yang terjadi maka harus ada tindakan keselamatan. Tindakan keselamatan berfungsi untuk mengurangi dampak terjadinya kecelakaan. Tindakan keselamatan berdasarkan penyebabnya dapat dikelompokkan menjadi:

1. Tindakan penyelamatan karena bahaya radioaktif

Hal-hal yang dapat dilakukan dalam upaya tindakan penyelamatan adalah:

a) Tidak panik

b) Menjauhi sumber radiasi sampai jarak aman

c) Menghindari menyentuh bahan yang telah terkontaminasi dengan bahan radioaktif

d) Tidak mengkonsumsi makanan yang telah terkontaminasi bahan radioaktif

2. Tindakan penyelamatan terkena bahan kimia

Hal-hal yang dapat dilakukan dalam upaya tindakan penyelamatan adalah:

a) Tidak panik

b) Membersihkan bagian tubuh yang mengalami kontak dengan bahan kimia (dapat menggunakan air untuk mencucinya)

c) Tidak menggaruk kulit yang terkena bahan kimia agar tidak menyebar

d) Mencari tempat yang banyak oksigen

e) Segera ke pusat kesehatan seperti klinik, puskesmas, rumah sakit 
3. Tindakan penyelamatan karena gempa bumi Hal-hal yang dapat dilakukan dalam upaya tindakan penyelamatan adalah:

a) Tidak panik

b) Berlindung di bawah meja, lemari

c) Menjauhi bangunan yang tinggi seperti lemari penyimpanan bahan kimia dan kaca

d) Memperhatikan bahaya lain seperti kebakaran yang diakibatkan arus pendek listrik, atau kebocoran gas

e) Mengevakuasi siswa ke lapangan terbuka untuk mengantisipasi gempa susulan

4. Tindakan penyelamatan karena kebakaran

Kebakaran dapat terjadi karena arus pendek, kebocoran gas, ataupun pemanasan zat yang mudah terbakar. Hal-hal yang dapat dilakukan dalam upaya tindakan penyelamatan adalah:

a) Apabila kebakaran mengenai baju atau tubuh, maka harus segera merebahkan diri sambil berguling-guling atau menggunakan selimut dan ditutupkan pada apinya agar cepat padam

b) Apabila terjadi kebakaran kecil, misalnya terbakarnya larutan dalam gelas kimia, menutup bagian yang terkena api dengan karung atau kain basah

c) Menggunakan alat pemadam kebakaran apabila terjadi kebakaran besar

d) Apabila kebakaran disebabkan zat yang mudah terbakar seperti bensin atau alkohol, untuk mematikannya dapat menggunakan pasir atau pemadam kebakaran jenis busa atau serbuk

5. Tindakan penyelamatan karena luka

Luka yang terjadi pada saat melakukan praktikum dapat berupa luka sayatan yang mengakibatkan perdarahan dan luka bakar. Hal-hal yang dapat dilakukan untuk menghentikan perdarahan luka sayatan adalah:

a) Menekan pada bagian yang luka dengan lembut menggunakan kain bersih atau perban 
b) Menggunakan air bersih yang mengalir untuk membersihkan luka

c) Setelah luka dibersihkan, mengoleskan antibiotik pada luka

d) Menutup luka menggunakan kain kasa atau plester

e) Mengganti perban setiap hari dan luka tidak terkena air selama masa penyembuhan

f) Meminum obat untuk menghentikan peradangan atau nyeri Perawatan untuk luka bakar berbeda dengan luka sayatan. Luka bakar dapat dibedakan menjadi tiga tingkat, yaitu:

a) Tingkat pertama

Luka bakar pada tingkat pertama paling sedikit merusak jaringan kulit. Area yang terluka adalah kulit bagian paling luar sehingga disebut luka bakar ringan. Tanda luka bakar ringan adalah kemerahan, bengkak, peradangan ringan, rasa sakit, kulit akan kering dan terkelupas ketika luka sembuh. Cara merawat luka bakar tingkat pertama adalah:

1) Merendam luka dengan air dingin selama 5 menit atau lebih

2) Meminum obat analgesik untuk mengurangi rasa sakit

3) Mengeringkan luka dan mengoleskan salep antibiotik

4) Dapat menggunakan kain kasa untuk melindungi luka

b) Tingkat kedua

Luka bakar tingkat kedua lebih serius dibandingkan tingkat pertama karena merusak lapisan atas kulit. Luka ini akan menyebabkan kulit melepuh, menjadi sangat merah, dan luka yang lebih parah. Cara merawat luka bakar tingkat kedua adalah:

1) Merendam luka dengan air dingin selama 5 menit atau lebih

2) Mengkonsumsi obat penghilang rasa sakit seperti ibuprofen atau acetaminophen

3) Mengoleskan krim atau salep antibiotik

4) Menghubungi dokter bila area luka besar

c) Tingkat ketiga

Luka bakar tingkat ketiga merupakan luka bakar paling parah karena mengalami kerusakan besar pada kulit bahkan hampir 
seluruh kulit. Luka bakar tingkat ketiga dapat merusak sampai ke saraf. Luka ini ditandai dengan gosong, melepuh, muncul warna putih seperti lilin, dan kulit yang terbuka. Luka bakar tingkat tiga tidak dapat diobati secara mandiri tetapi memerlukan penanganan medis. Operasi merupakan cara untuk memperbaiki kerusakan kulit.

Mengingat besarnya dampak kecelakaan, maka setiap laboratorium harus menyediakan kotak P3K sebagai upaya pertolongan pertama. Tindakan P3K dilakukan sebelum menemui dokter untuk pengobatan lebih lanjut. Tujuan dilakukan kegiatan P3K adalah:

1) Menyelamatkan korban

2) Mencegah terjadinya cedera yang lebih besar sehingga dapat meringankan beban korban

3) Mempertahankan daya tahan korban sampai pertolongan medis datang 


\section{DAFTAR PUSTAKA}

Charmelia, V. (2017). SOP (Standar Oprasional Prosedur) laboratorium IPA. Diakses https://fsk16avivi.blogspot.com/2017/05/sop-standar-oprasionalprosedur.html

Hibbard, K. Michael. 1997. Performance Assessment in The Science Classroom. New York: McGraw-Hill.

Ibrahim, Muslimin. 2005. Asesmen Berkelanjutan: Konsep Dasas, Tahapan Pengembangan dan Contoh. Surabaya: Unesa University Press.

Rosada, D., Kadarisman, N. \& Raharjo.(2017). Panduan pengelolaan dan pemanfaatan laboratorium IPA. Jakarta: Kemendikbud.

Suyidno, 2017,. Standart Operasional Laboratorium. UNLAM 
Lampiran 1. Format A (Contoh Data Gedung dan Ruangan Laboratorium)

Data Gedung dan Ruangan Laboratorium

Nama Sekolah:

Nama Laboratorium :

\begin{tabular}{|c|c|c|c|c|}
\hline No & Jenis Ruangan & Luas $\left(\mathrm{m}^{2}\right)$ & Luas Ideal $\left(\mathrm{m}^{2}\right)$ & Rincian Usulan Pengembangan \\
\hline & & & & \\
\hline & & & & \\
\hline & & & & \\
\hline & & & & \\
\hline & & & & \\
\hline & & & & \\
\hline
\end{tabular}

Sidoarjo, 2020

Mengetahui,

Kepala Sekolah

Kepala Laboratorium

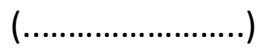

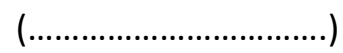




\section{Lampiran 2. Format B1 (Contoh Kartu Barang)}

Kartu Barang Laboratorium

\section{Nama Sekolah:}

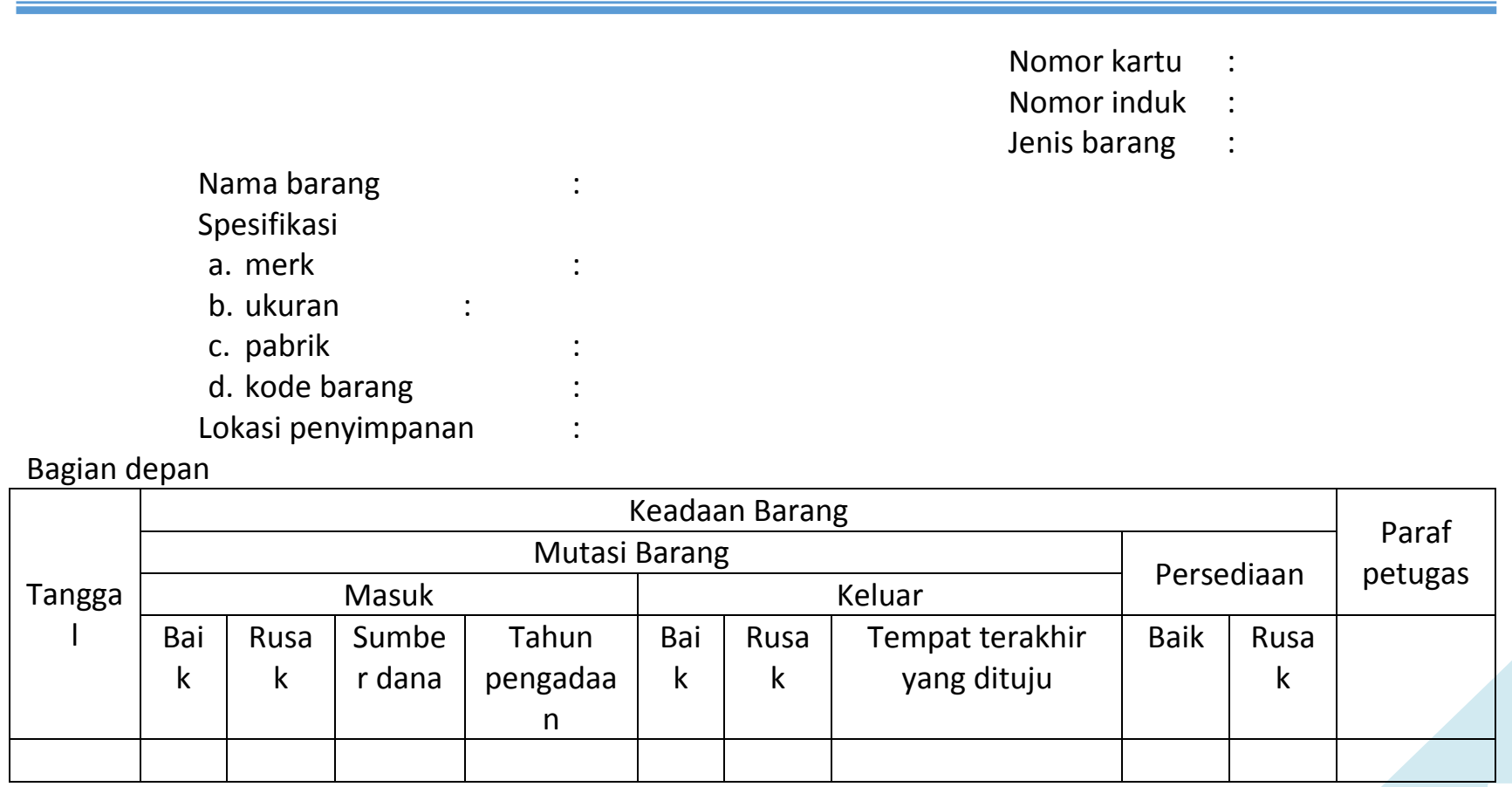




\begin{tabular}{|c|c|c|c|c|c|c|c|c|c|c|}
\hline \multirow{4}{*}{$\begin{array}{c}\text { Tangga } \\
\text { I }\end{array}$} & \multicolumn{9}{|c|}{ Keadaan Barang } & \multirow{3}{*}{$\begin{array}{c}\text { Paraf } \\
\text { petugas }\end{array}$} \\
\hline & \multicolumn{7}{|c|}{ Mutasi Barang } & \multirow{2}{*}{\multicolumn{2}{|c|}{ Persediaan }} & \\
\hline & \multicolumn{4}{|c|}{ Masuk } & \multicolumn{3}{|c|}{ Keluar } & & & \\
\hline & $\begin{array}{c}\text { Bai } \\
k\end{array}$ & $\begin{array}{c}\text { Rusa } \\
k\end{array}$ & $\begin{array}{l}\text { Sumbe } \\
\text { r dana }\end{array}$ & $\begin{array}{c}\text { Tahun } \\
\text { pengadaa } \\
\mathrm{n}\end{array}$ & $\begin{array}{c}\text { Bai } \\
k\end{array}$ & $\begin{array}{c}\text { Rusa } \\
k\end{array}$ & $\begin{array}{c}\text { Tempat terakhir } \\
\text { yang dituju }\end{array}$ & Baik & $\begin{array}{c}\text { Rusa } \\
\mathrm{k}\end{array}$ & \\
\hline & & & & & & & & & & \\
\hline
\end{tabular}

Bagian belakang

\begin{tabular}{|l|l|l|l|l|l|}
\hline \multirow{2}{*}{ Tanggal } & \multicolumn{3}{|c|}{ Riwayat Barang } & \multirow{2}{*}{$\begin{array}{c}\text { Paraf } \\
\text { petugas }\end{array}$} & \multirow{2}{*}{ Keterangan } \\
\cline { 2 - 5 } & $\begin{array}{c}\text { Pemeliharaan } \\
\text { atau perawatan }\end{array}$ & Dikerjakan oleh & $\begin{array}{c}\text { Biaya dan Sumber } \\
\text { dana }\end{array}$ & & \\
\hline & & & & & \\
\hline & & & & & \\
\hline & & & & & \\
\hline & & & & & \\
\hline
\end{tabular}


Lampiran 3. Format B2 (Contoh Daftar Barang atau Buku Induk)

Daftar Barang Laboratorium

Nama Sekolah:

\begin{tabular}{|l|c|c|c|l|l|l|l|l|l|l|}
\hline \multirow{2}{*}{ No } & No & No & Kode & Nama & \multicolumn{3}{|c|}{ Spesifikasi Barang } & \multicolumn{2}{|c|}{ Jumlah } & Keterangan \\
\hline & & & & & & & & & & \\
\hline & & & & & & & & & & \\
\hline & & & & & & & & & & \\
\hline & & & & & & & & & & \\
\hline & & & & & & & & & \\
\hline & & & & & & & & & & \\
\hline & & & & & & & & & & \\
\hline
\end{tabular}

Sidoarjo, 2020

Mengetahui, Kepala Sekolah

Kepala Laboratorium

Laboran

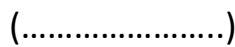

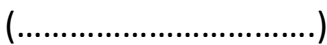

$(\ldots \ldots \ldots \ldots \ldots \ldots \ldots . . .$. 
Lampiran 4. Format B3 (Contoh Daftar Penerimaan atau Pengeluaran Barang)

Daftar Penerimaan atau Pengeluaran Barang Laboratorium Nama Sekolah:

\begin{tabular}{|c|c|c|c|c|c|c|c|c|c|c|}
\hline \multirow{2}{*}{ No } & \multirow{2}{*}{$\begin{array}{c}\text { No } \\
\text { Kartu }\end{array}$} & \multirow{2}{*}{$\begin{array}{l}\text { No } \\
\text { Induk }\end{array}$} & \multirow{2}{*}{$\begin{array}{c}\text { Kode } \\
\text { Barang }\end{array}$} & \multirow{2}{*}{$\begin{array}{l}\text { Nama } \\
\text { Barang }\end{array}$} & \multicolumn{3}{|c|}{ Spesifikasi Barang } & \multicolumn{2}{|c|}{ Jumlah } & \multirow[t]{2}{*}{ Keterangan } \\
\hline & & & & & Merk & Ukuran & Pabrik & Baik & Rusak & \\
\hline & & & & & & & & & & \\
\hline & & & & & & & & & & \\
\hline & & & & & & & & & & \\
\hline & & & & & & & & & & \\
\hline & & & & & & & & & & \\
\hline & & & & & & & & & & \\
\hline
\end{tabular}

Sidoarjo, 2020

Yang menyerahkan, (Sebagai ...)

Penerima,

(Sebagai ...)

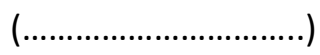

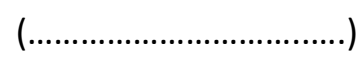


Lampiran 5. Format B4 (Contoh Daftar Permintaan atau Usulan Barang)

Daftar Usulan Perbaikan atau Pengadaan Barang Laboratorium Nama Sekolah:

\begin{tabular}{|c|c|c|c|c|c|c|c|c|c|c|}
\hline \multirow[b]{2}{*}{ No } & \multirow{2}{*}{$\begin{array}{c}\text { No } \\
\text { Kartu }\end{array}$} & \multirow{2}{*}{$\begin{array}{c}\text { No } \\
\text { Induk }\end{array}$} & \multirow{2}{*}{$\begin{array}{l}\text { Kode } \\
\text { Barang }\end{array}$} & \multirow{2}{*}{$\begin{array}{l}\text { Nama } \\
\text { Barang }\end{array}$} & \multicolumn{3}{|c|}{ Spesifikasi Barang } & \multirow[b]{2}{*}{ Jumlah } & \multirow{2}{*}{$\begin{array}{c}\text { Harga } \\
\text { satuan } \\
\text { (Rp) }\end{array}$} & \multirow[b]{2}{*}{$\begin{array}{c}\text { Harga } \\
\text { total (Rp) }\end{array}$} \\
\hline & & & & & Merk & Ukuran & Pabrik & & & \\
\hline & & & & & & & & & & \\
\hline & & & & & & & & & & \\
\hline & & & & & & & & & & \\
\hline & & & & & & & & & & \\
\hline & & & & & & & & & & \\
\hline
\end{tabular}

Sidoarjo, 2020

Mengetahui, Kepala Sekolah

Kepala Laboratorium

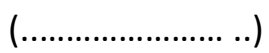

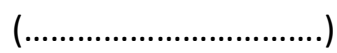




\section{Lampiran 6. Format C1 (Contoh Kartu Alat)}

Kartu Alat Laboratorium

Nama Sekolah:

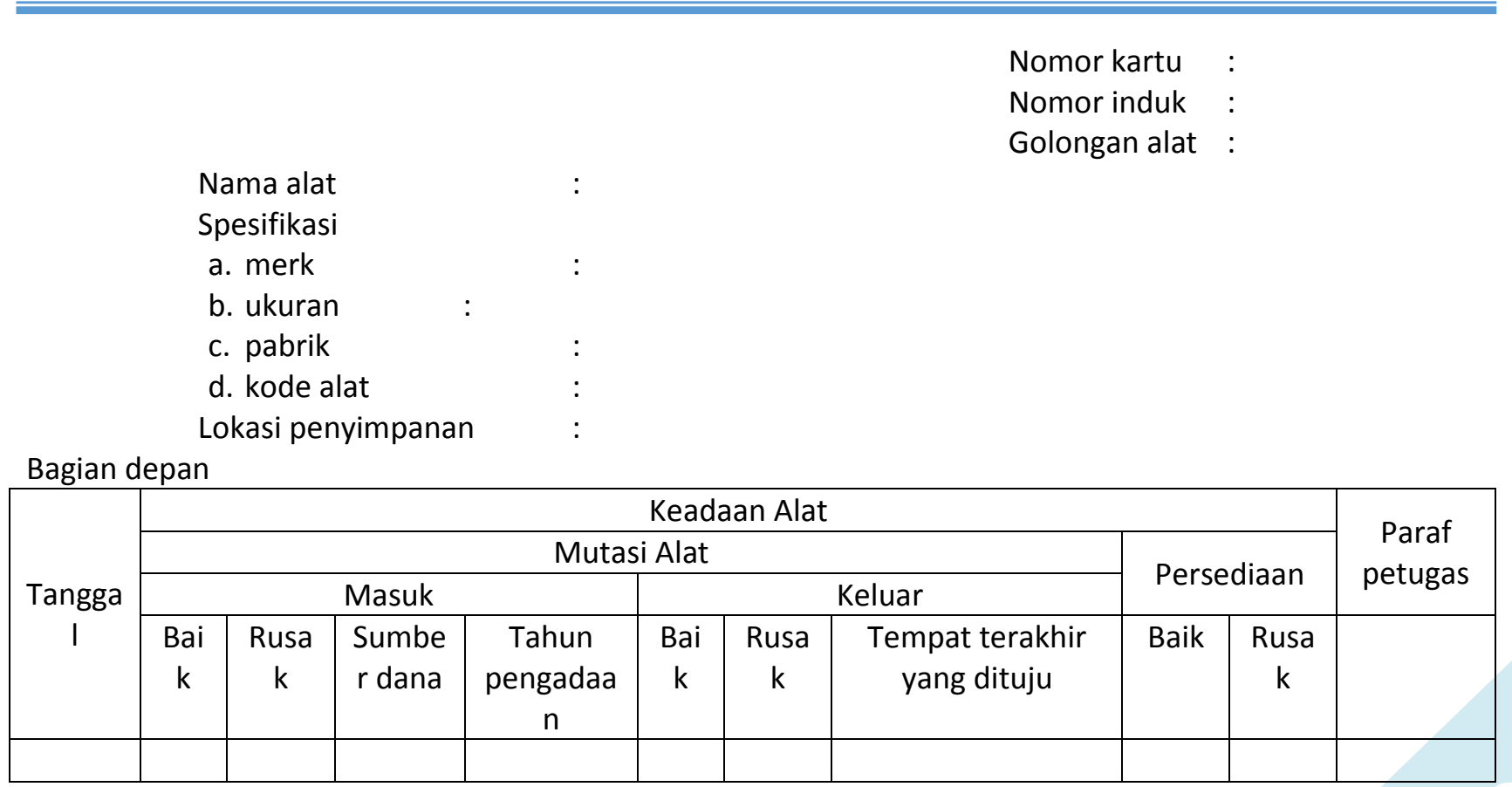




\begin{tabular}{|c|c|c|c|c|c|c|c|c|c|c|}
\hline \multirow{4}{*}{$\begin{array}{c}\text { Tangga } \\
\text { I }\end{array}$} & \multicolumn{9}{|c|}{ Keadaan Alat } & \multirow{3}{*}{$\begin{array}{c}\text { Paraf } \\
\text { petugas }\end{array}$} \\
\hline & \multicolumn{7}{|c|}{ Mutasi Alat } & \multirow{2}{*}{\multicolumn{2}{|c|}{ Persediaan }} & \\
\hline & \multicolumn{4}{|c|}{ Masuk } & \multicolumn{3}{|c|}{ Keluar } & & & \\
\hline & $\begin{array}{c}\text { Bai } \\
k\end{array}$ & $\begin{array}{c}\text { Rusa } \\
k\end{array}$ & $\begin{array}{l}\text { Sumbe } \\
\text { r dana }\end{array}$ & $\begin{array}{c}\text { Tahun } \\
\text { pengadaa } \\
\mathrm{n}\end{array}$ & $\begin{array}{c}\text { Bai } \\
k\end{array}$ & $\begin{array}{c}\text { Rusa } \\
k\end{array}$ & $\begin{array}{c}\text { Tempat terakhir } \\
\text { yang dituju }\end{array}$ & Baik & $\begin{array}{c}\text { Rusa } \\
\mathrm{k}\end{array}$ & \\
\hline & & & & & & & & & & \\
\hline
\end{tabular}

\section{Bagian belakang}

\begin{tabular}{|l|l|l|l|l|l|}
\hline \multirow{2}{*}{ Tanggal } & \multicolumn{3}{|c|}{ Riwayat Alat } & \multirow{2}{*}{$\begin{array}{c}\text { Paraf } \\
\text { petugas }\end{array}$} & \multirow{2}{*}{ Keterangan } \\
\cline { 2 - 5 } & $\begin{array}{c}\text { Pemeliharaan } \\
\text { atau perawatan }\end{array}$ & Dikerjakan oleh & $\begin{array}{c}\text { Biaya dan Sumber } \\
\text { dana }\end{array}$ & & \\
\hline & & & & & \\
\hline & & & & & \\
\hline & & & & & \\
\hline & & & & & \\
\hline
\end{tabular}


Format C2 (Contoh Daftar Alat atau Buku Induk)

Daftar Alat Laboratorium

Nama Sekolah:

\begin{tabular}{|c|c|c|c|c|c|c|c|c|c|c|}
\hline \multirow{2}{*}{ No } & \multirow{2}{*}{$\begin{array}{c}\text { No } \\
\text { Kartu }\end{array}$} & \multirow{2}{*}{$\begin{array}{l}\text { No } \\
\text { Induk }\end{array}$} & \multirow{2}{*}{$\begin{array}{l}\text { Kode } \\
\text { Alat }\end{array}$} & \multirow{2}{*}{$\begin{array}{c}\text { Nama } \\
\text { Alat }\end{array}$} & \multicolumn{3}{|c|}{ Spesifikasi Alat } & \multicolumn{2}{|c|}{ Jumlah } & \multirow[t]{2}{*}{ Keterangan } \\
\hline & & & & & Merk & Ukuran & Pabrik & Baik & Rusak & \\
\hline & & & & & & & & & & \\
\hline & & & & & & & & & & \\
\hline & & & & & & & & & & \\
\hline & & & & & & & & & & \\
\hline & & & & & & & & & & \\
\hline & & & & & & & & & & \\
\hline & & & & & & & & & & \\
\hline
\end{tabular}

Sidoarjo, 2020

Mengetahui, Kepala Sekolah

Kepala Laboratorium

Laboran

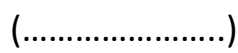

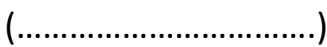

$(\ldots \ldots \ldots \ldots \ldots \ldots \ldots . . .$. 
Format C3 (Contoh Daftar Penerimaan atau Pengeluaran Alat)

Daftar Penerimaan atau Pengeluaran Alat Laboratorium Nama Sekolah:

\begin{tabular}{|c|c|c|c|c|c|c|c|c|c|c|}
\hline \multirow{2}{*}{ No } & \multirow{2}{*}{$\begin{array}{l}\text { No } \\
\text { Kartu }\end{array}$} & \multirow{2}{*}{$\begin{array}{c}\text { No } \\
\text { Induk }\end{array}$} & \multirow{2}{*}{$\begin{array}{l}\text { Kode } \\
\text { Alat }\end{array}$} & \multirow{2}{*}{$\begin{array}{c}\text { Nama } \\
\text { Alat }\end{array}$} & \multicolumn{3}{|c|}{ Spesifikasi Alat } & \multicolumn{2}{|c|}{ Jumlah } & \multirow[t]{2}{*}{ Keterangan } \\
\hline & & & & & Merk & Ukuran & Pabrik & Baik & Rusak & \\
\hline & & & & & & & & & & \\
\hline & & & & & & & & & & \\
\hline & & & & & & & & & & \\
\hline & & & & & & & & & & \\
\hline & & & & & & & & & & \\
\hline & & & & & & & & & & \\
\hline
\end{tabular}

Sidoarjo, 2020

Yang menyerahkan, (Sebagai ...)

Penerima,

(Sebagai ...)

$($ (.............................)

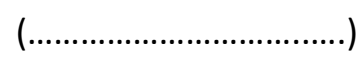


Format C4 (Contoh Daftar Permintaan atau Usulan Alat)

Daftar Usulan Perbaikan atau Pengadaan Alat Laboratorium Nama Sekolah:

\begin{tabular}{|c|c|c|c|c|c|c|c|c|c|c|}
\hline \multirow[b]{2}{*}{ No } & \multirow[b]{2}{*}{$\begin{array}{c}\text { No } \\
\text { Kartu }\end{array}$} & \multirow[b]{2}{*}{$\begin{array}{l}\text { No } \\
\text { Induk }\end{array}$} & \multirow[b]{2}{*}{$\begin{array}{l}\text { Kode } \\
\text { Alat }\end{array}$} & \multirow[b]{2}{*}{$\begin{array}{c}\text { Nama } \\
\text { Alat }\end{array}$} & \multicolumn{3}{|c|}{ Spesifikasi Alat } & \multirow[b]{2}{*}{ Jumlah } & \multirow{2}{*}{$\begin{array}{c}\text { Harga } \\
\text { satuan } \\
(R p)\end{array}$} & \multirow[b]{2}{*}{$\begin{array}{c}\text { Harga } \\
\text { total }(R p)\end{array}$} \\
\hline & & & & & Merk & Ukuran & Pabrik & & & \\
\hline & & & & & & & & & & \\
\hline & & & & & & & & & & \\
\hline & & & & & & & & & & \\
\hline & & & & & & & & & & \\
\hline & & & & & & & & & & \\
\hline
\end{tabular}

Sidoarjo, 2020

Mengetahui, Kepala Sekolah

Kepala Laboratorium

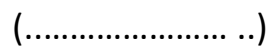

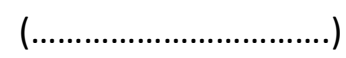


Lampiran 7. Format D1 (Contoh Kartu Bahan Kimia atau Zat)

Kartu Zat Laboratorium

Nama Sekolah:

Nama zat

Nomor kartu

Nomor induk :

Golongan zat

Spesifikasi

a. rumus kimia

b. $\mathrm{Mr}$

c. kemurnian

d. konsentrasi

e. wujud

f. warna

g. kode zat

h. pabrik

Lokasi penyimpanan 


\begin{tabular}{|c|c|c|c|c|c|c|c|c|c|c|}
\hline \multirow{4}{*}{ Tanggal } & \multicolumn{9}{|c|}{ Keadaan Zat } & \multirow{4}{*}{$\begin{array}{l}\text { Paraf } \\
\text { petugas }\end{array}$} \\
\hline & \multicolumn{7}{|c|}{ Mutasi Zat } & \multirow{2}{*}{\multicolumn{2}{|c|}{ Persediaan }} & \\
\hline & \multicolumn{4}{|c|}{ Masuk } & \multicolumn{3}{|c|}{ Keluar } & & & \\
\hline & Baik & Rusak & $\begin{array}{c}\text { Sumber } \\
\text { dana }\end{array}$ & $\begin{array}{c}\text { Tahun } \\
\text { pengadaan }\end{array}$ & Baik & Rusak & $\begin{array}{c}\text { Tempat terakhir } \\
\text { yang dituju }\end{array}$ & Baik & Rusak & \\
\hline & & & & & & & & & & \\
\hline & & & & & & & & & & \\
\hline & & & & & & & & & & \\
\hline & & & & & & & & & & \\
\hline & & & & & & & & & & \\
\hline & & & & & & & & & & \\
\hline & & & & & & & & & & \\
\hline & & & & & & & & & & \\
\hline & & & & & & & & & & \\
\hline & & & & & & & & & & \\
\hline & & & & & & & & & & \\
\hline & & & & & & & & & & \\
\hline & & & & & & & & & & \\
\hline
\end{tabular}


Format D2 (Contoh Daftar Zat atau Buku Induk)

Daftar Bahan Kimia atau Zat di Laboratorium Nama Sekolah:

\begin{tabular}{|l|c|c|c|c|c|c|c|c|c|c|c|}
\hline \multirow{2}{*}{ No } & $\begin{array}{c}\text { No } \\
\text { Kartu }\end{array}$ & No & Kode & Nama & Rumus & \multicolumn{3}{|c|}{ Spesifikasi Zat } & Jumlah & Ket \\
\hline & & & & & & & & & & & \\
\hline & & & & & & & & & & & \\
\hline & & & & & & & & & & & \\
\hline & & & & & & & & & & & \\
\hline & & & & & & & & & & & \\
\hline & & & & & & & & & & & \\
\hline & & & & & & & & & & & \\
\hline
\end{tabular}

Sidoarjo, 2020

Mengetahui, Kepala Sekolah

Kepala Laboratorium

Laboran

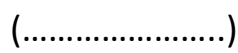

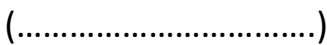

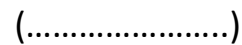


Format D3 (Contoh Daftar Penerimaan atau Pengeluaran Zat)

Daftar Penerimaan atau Pengeluaran Zat di Laboratorium Nama Sekolah:

\begin{tabular}{|l|c|c|c|c|c|c|c|c|c|c|c|}
\hline \multirow{2}{*}{ No } & No & No & Kode & Nama & Rumus & \multicolumn{3}{|c|}{ Spesifikasi Zat } & \multicolumn{2}{|c|}{ Jumlah } & Ket \\
\cline { 6 - 12 } & Kartu & Induk & Zat & Zat & Kimia & Konsentrasi & Wujud & Warna & Baik & Rusak & \\
\hline & & & & & & & & & & & \\
\hline & & & & & & & & & & & \\
\hline & & & & & & & & & & & \\
\hline & & & & & & & & & & & \\
\hline & & & & & & & & & & & \\
\hline & & & & & & & & & & & \\
\hline
\end{tabular}

Sidoarjo, 2020

Yang menyerahkan, (Sebagai ...)

Penerima,

(Sebagai ...)

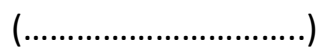

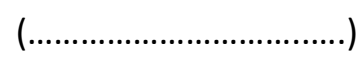


Format D4 (Contoh Daftar Permintaan atau Usulan Zat)

Daftar Usulan Perbaikan atau Pengadaan Zat di Laboratorium Nama Sekolah:

\begin{tabular}{|l|c|c|c|c|c|c|c|c|c|c|c|}
\hline \multirow{2}{*}{ No } & No & No & Kode & Nama & Rumus & \multicolumn{3}{|c|}{ Spesifikasi Zat } & \multicolumn{2}{|c|}{ Jumlah } & Ket \\
\cline { 6 - 12 } & Kartu & Induk & Zat & Zat & Kimia & Konsentrasi & Wujud & Warna & Baik & Rusak & \\
\hline & & & & & & & & & & & \\
\hline & & & & & & & & & & & \\
\hline & & & & & & & & & & & \\
\hline & & & & & & & & & & & \\
\hline & & & & & & & & & & & \\
\hline & & & & & & & & & & & \\
\hline
\end{tabular}

Sidoarjo, 2020

Mengetahui, Kepala Sekolah

Kepala Laboratorium

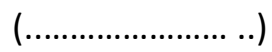

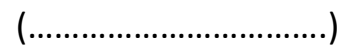




\section{Lampiran 8. LKS PROSES SAINS}

Jayanti merupakan seorang siswa SMP x. Dia diminta oleh guru untuk melakukan kegiatan penelitian yang bertujuan: "Mengetahui hubungan jumlah pemberian asam cuka terhadap berat nata de coco yang dihasilkan."

Sebagai seorang siswa SMP yang telah mempelajari tentang kerja ilmiah, anda diminta untuk membantu Jayanti dalam membuat perencanaan-perencanaan yang meliputi: perumusan masalah dan pengajuan hipotesis

Butir 1 : Merumuskan Pertanyaan (skor 8)

Rumusan masalah yang akan dipecahkan Jayanti yang terkait dengan Wacana 1 adalah:

Butir 2: Merumuskan Hipotesis (skor 8

Rumusan hipotesis yang akan diuji terkait rumusan masalah di atas dan Wacana 1 adalah: 
Proses pembuatan tape ketan relatif mudah. Mulanya beras ketan dicuci bersih lalu dikukus kemudian didinginkan, Selanjutnya menaburinya dengan ragi. Dan pada saat peragian ini, terjadi perubahan bentuk dari pati menjadi glukosa yang pada akhirnya menghasilkan alkohol. Proses yang terjadi inilah dinamakan dengan proses fermentasi.

Sebagai seorang siswa SMP yang telah akrap dengan metode ilmiah, anda diminta untuk menentukan variabel penelitian dengan mengacu rumusan masalahnya dan hipotesis sebagai berikut:

Rumusan masalah:

“Apakah pengaruh jumlah pemberian ragi terhadap kualitas hasil fermentasi pada tape?"

Hipotesis:

"Semakin banyak pemberian ragi maka kualitas hasil fermentasinya semakin baik?"

Variabel yang akan saya ubah-ubah, variabel yang saya ukur dan variabel yang saya buat dalam percobaan terkait Wacana 2 adalah sebagai berikut:

Butir 3: Menentukan Variabel Manipulasi (skor 8)

VM: (Apa yang kamu ubah) 
Butir 4: Mendefinisikan Variabel Manipulasi Secara

Operasional (skor 8)

DOVM: (Bagaimana kamu mengubahnya)

Butir 5: Menentukan Variabel Respon (skor 8)

VR: (Apa yang kamu amati atau kamu ukur)

Butir 6: Mendefinisikan Variabel Respon Secara Operasional (skor 8)

DOVR: (Bagaimana kamu mengukurnya)

Butir 7 Menentukan Variabel Kontrol (skor 8)

VK: (Apa yang kamu jaga supaya kondisinya sama) 
Si Mita, adalah siswa dari SMP Unesa. Dia mendapat tugas dari gurunya untuk melakukan penelitian tentang proses pembuatan nata de coco, yaitu mencari tahu tentang hubungan jumlah pemberian urea terhadap kualitas nata de coco yang dihasilkan.

Dalam penelitian yang ia lakukan dia memilih rumusan masalahnya sebagai berikut:

Apakah pengaruh jumlah pemberian urea terhadap berat nata de coco yang dihasilkan?

Dari rumusan masalah tersebut dia berhipotesis bahwa,

Semakin banyak jumlah pemberian urea maka semakin berat nata de coco yang dihasilkan.

Setelah dilaksanakan penelitian maka dia memperoleh data sebagai berikut: Untuk nata de coco yang diberikan diberi urea $20 \mathrm{~g}$ berat nata yang dihasilkan $450 \mathrm{~g}$. Untuk nata de coco yang

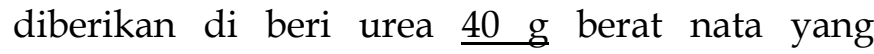
dihasilkan $400 \mathrm{~g}$. Dan nata de coco yang diberikan

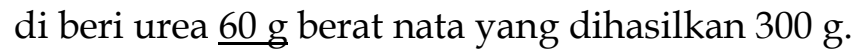

Sebagai teman bantulah Mita untuk mengorganisaikan data dalam bentuk nata de coco, menganalisis data, dan menarik kesimpulan dari hasil penelitianya. 
Butir 8 Mengorganisasikan Data dalam Bentuk Tabel (skor 8)

Organisasikan data yang ada Wacana 03 dalam bentuk tabel pada kolom tabel di bawah ini

Butir 9 Menganalisis Data (skor 8)

Perhatikan hasil Wacana 03 dan tabel yang telah kamu buat. Apakah terdapat perbedaan? Dalam hal apakah perbedaannya? Jelaskan

- Perhatikan Wacana 03 dan tabel hasil eksperimen. Apakah terdapat perbedaan?

- Dalam hal apakah perbedaannya hasil eksperimenmu? Jelaskan! 
Butir 10 Menarik Kesimpulan (skor 8)

- Apakah data hasil pengamatanmu mendukung hipotesismu?

- Apa kesimpulan yang dapat kamu rumuskan terkait hipotesismu?

---- Semoga Berhasil ----

\begin{tabular}{|l|l|}
\hline \multicolumn{2}{|c|}{ Skor } \\
\hline Siswa: & Guru: \\
\hline Nilai : & \\
& \\
& \\
\hline
\end{tabular}




\section{LAMPIRAN 2}

\section{KUNCI LEMBAR PENLAIAN}

Jayanti merupakan seorang siswa SMP Unesa. Dia diminta oleh guru untuk melakukan kegiatan penelitian yang bertujuan: "Mengetahui hubungan jumlah pemberian asam cuka terhadap berat nata de coco yang dihasilkan."

Sebagai seorang siswa SMP yang telah mempelajari tentang kerja ilmiah, anda diminta untuk membantu Jayanti dalam membuat perencanaan-perencanaan yang meliputi: perumusan masalah dan pengajuan hipotesis.

Butir 1 : Merumuskan pertanyaan (skor 10)

Rumusan masalah yang akan dipecahkan Jayanti yang terkait dengan Wacana 1 adalah:

Apakah (bagaimana) pengaruh jumlah pemberian jumlah asam cuka terhadap berat nata de coco yang dihasilkan?.

Butir 2: Merumuskan Hipotesis (skor 10)

Rumusan hipotesis yang akan diuji terkait rumusan masalah di atas dan Wacana 1 adalah :

Semakin banyak jumlah pemberian asam cuka maka semakin berat nata de coco yang dihasilkan. 
Proses pembuatan tape ketan relatif mudah. Mulanya beras ketan dicuci bersih lalu dikukus kemudian didinginkan, Selanjutnya menaburinya dengan ragi. Dan pada saat peragian ini, terjadi perubahan bentuk dari pati menjadi glukosa yang pada akhirnya menghasilkan alkohol. Proses yang terjadi inilah dinamakan dengan proses fermentasi.

Sebagai seorang siswa SMP yang telah akrab dengan metode ilmiah, anda diminta untuk menentukan variabel penelitian dengan mengacu rumusan masalahnya dan hipotesis sebagai berikut:

Rumusan masalah:

"Apakah pengaruh jumlah pemberian ragi terhadap kualitas hasil fermentasi pada tape?"

Hipotesis:

"Semakin banyak pemberian ragi maka kualitas hasil fermentasinya semakin baik?"

Variabel yang akan saya ubah-ubah, variabel yang saya ukur dan variabel yang saya buat dalam percobaan terkait Wacana 2 adalah sebagai berikut:

Butir 3: Menentukan Variabel Manipulasi (skor 10)

VM: (Apa yang kamu ubah) 
Jumlah pemberian ragi tape

Butir 4: Mendefinisikan Variabel Manipulasi Secara Operasional (skor 10)

DOVM: (Bagaimana kamu mengubahnya)

Jumlah ragi tape yang diberikan yaitu $2 \mathrm{~g}, 4 \mathrm{~g}$, dan $6 \mathrm{~g}$

Butir 5: Menentukan Variabel Respon (skor 10)

VR: (Apa yang kamu amati atau kamu ukur)

Kualitas hasil fermentasi

Butir 6: Mendefinisikan Variabel Respon Secara Operasional (skor 10)

DOVR: (Bagaimana kamu mengukurnya)

Kualitas hasil tape diukur berdasarkan kriteria tape yang baik, yaitu:

Rasanya manis (semakin manis semakin baik)

Kandungan air(semakin sedikit kandungan air semakin baik) 
Butir 7 Menentukan Variabel Kontrol (skor 10)

VK: (Apa yang kamu jaga supaya kondisinya sama)

Jenis ketan, suhu, jenis ragi, jumlah ketan

Si Mita, adalah siswa dari SMP Unesa. Dia mendapat tugas dari gurunya untuk melakukan penelitian tentang proses pembuatan nata de coco, yaitu mencari tahu tentang hubungan jumlah pemberian urea terhadap kualitas nata de coco yang dihasilkan.

Dalam penelitian yang ia lakukan dia memilih rumusan masalahnya sebagai berikut:

Apakah pengaruh jumlah pemberian urea terhadap berat nata de coco yang dihasilkan?

Dari rumusan masalah tersebut dia berhipotesis bahwa,

Semakin banyak jumlah pemberian urea maka semakin berat nata de coco yang dihasilkan.

Setelah dilaksanakan penelitian maka dia memperoleh data sebagia berikut: Untuk nata de

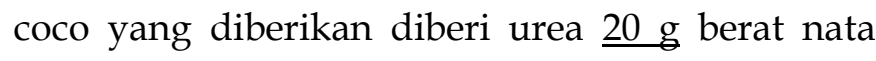
yang dihasilkan $450 \mathrm{~g}$. Untuk nata de coco yang diberikan di beri urea $\underline{40 \mathrm{~g}}$ berat nata yang 
dihasilkan $400 \mathrm{~g}$. Dan nata de coco yang diberikan di beri urea $60 \mathrm{~g}$ berat nata yang dihasilkan $300 \mathrm{~g}$.

Sebagai teman bantulah Mita untuk mengorganisaikan data dalam bentuk nata de coco, menganalisis data, dan menarik kesimpulan dari hasil penelitianya.

Butir 8 Mengorganisasikan data dalam bentuk tabel (skor 10)

Organisasikan data yang ada Wacana 03 dan organisasikanlah dalam bentuk tabel.

Tuliskan tabel kamu pada kolom tabel di bawah ini

Butir 9 Menganalisis Data (skor 10)

Perhatikan hasil Wacana 03 dan tabel yang telah kamu buat. Apakah terdapat perbedaan? Dalam hal apakah perbedaannya? Jelaskan!

- Perhatikan Wacana 03 dan tabel hasil eksperimen. Apakah terdapat perbedaan?

Tidak 
- Dalam hal apakah perbedaannya hasil eksperimenmu? Jelaskan!

Berat nata de coco, dari data menunjukkan nata de coco yang beri urea $2 \mathrm{~mL}$ dengan beratnya $400 \mathrm{~g}$,

Berat nata de coco, dari data menunjukkan nata de coco yang beri urea $4 \mathrm{~mL}$ dengan beratnya $300 \mathrm{~g}$,

Berat nata de coco, dari data menunjukkan nata de coco yang beri urea $6 \mathrm{~mL}$ dengan beratnya $200 \mathrm{~g}$,

Butir 10 Menarik Kesimpulan (skor 10)

- Apakah data hasil pengamatanmu mendukung hipotesismu?

Tidak

- Apa kesimpulan yang dapat kamu rumuskan terkait hipotesismu?

Semakin banyak urea yang diberikan, maka tidak semakin berat nata de coco yang dihasilkan.

---- Semoga Berhasil -----

\begin{tabular}{|l|l|}
\hline \multicolumn{2}{|c|}{ Skor } \\
\hline Siswa: & Guru: \\
\hline Nilai : & \\
& \\
& \\
\hline
\end{tabular}


Lampiran 3 Lembar Penilaian

LEMBAR KRITERIA

PENILAIAN PROSES SUMATIF
Mata Pelajaran
: Sains
Satuan Pendidikan
Kelas/ Semester
Materi Pokok
: SMP
: IX/ 1
: Bioteknologi

Nama:

Kelas:

Tanggal : 
1. Merumuskan masalah (Kriteria Proses 01)

\begin{tabular}{|c|c|c|c|}
\hline \multirow{3}{*}{ Aspek yang dinilai } & \multicolumn{3}{|c|}{ Skor penilaian } \\
\hline & \multirow[t]{2}{*}{$\begin{array}{l}\text { Skor } \\
\text { Maks }\end{array}$} & \multicolumn{2}{|c|}{$\begin{array}{l}\text { Skor yang } \\
\text { diberikan }\end{array}$} \\
\hline & & Siswa & Guru \\
\hline $\begin{array}{l}\text { 1. Rumusan masalah telah dipikirkan secara } \\
\text { seksama dan ada relevansinya }\end{array}$ & 5 & & \\
\hline 2. Rumusan masalah dipilih untuk pengamatan & 5 & & \\
\hline $\begin{array}{l}\text { 3. Rumusan masalah dapat diselidiki dengan } \\
\text { pengamatan }\end{array}$ & 5 & & \\
\hline Total skor & 15 & & \\
\hline
\end{tabular}

Keterangan : 5 = Amat Baik; 4 = Baik ; 3= Cukup ; 2 = Jelek ; 1= Amat Jelek. 


\section{RUBRIK}

\section{Merumuskan Masalah}

\begin{tabular}{|c|l|}
\hline 5 & $\begin{array}{l}\text { Siswa menunjukkan pemahaman yang hebat dengan merumuskan pertanyaan- } \\
\text { pertanyaan yang luar biasa dan menarik. Pemikiran ke arah lebih tinggi terlihat jelas. } \\
\text { Siswa memberikan suatu penjelasan yang begitu penuh pemikiran terhadap mengapa } \\
\text { suatu pertanyaan tertentu telah dipilih untuk meneliti lebih lanjut. }\end{array}$ \\
\hline 4 & $\begin{array}{l}\text { Siswa menunjukan pemahaman yang hebat dengan merumuskan pertanyaan-pertanyaan } \\
\text { yang luar biasa dan menarik. Siswa memberikan suatu penjelasan yang begitu penuh } \\
\text { pemikiran terhadap mengapa suatu pertanyaan tertentu telah dipilih untuk meneliti lebih } \\
\text { lanjut. }\end{array}$ \\
\hline 3 & $\begin{array}{l}\text { Pekerjaan siswa sepertinya dapat di beri nilai 4, kecuali ada suatu unsur penting yang } \\
\text { kurang baik mengerjakannya. }\end{array}$ \\
\hline 2 & $\begin{array}{l}\text { Daftar pertanyaan menunjukan sustu upaya kurang keras. Siswa tersebut tidak } \\
\text { memberikan penjelasan yang difikir secara seksama terhadap mengapa suatu } \\
\text { pertanyaan tertentu telah dipilih untuk meneliti lebih lanjut. }\end{array}$ \\
\hline 1 & \begin{tabular}{l} 
Pekerjaan yang dilakukan amat jelek atau tidak lengkap \\
\hline
\end{tabular} \\
\hline
\end{tabular}


2. Merumuskan Hipotesis (Kriteria Proses 02)

\begin{tabular}{|ll|c|c|c|}
\hline \multirow{2}{*}{ Aspek yang dinilai } & \multicolumn{2}{c|}{ Skor penilaian } \\
\cline { 3 - 5 } & $\begin{array}{c}\text { Skor } \\
\text { Maks }\end{array}$ & \multicolumn{2}{|c|}{$\begin{array}{c}\text { Skor yang } \\
\text { diberikan }\end{array}$} \\
\cline { 3 - 5 } & & Siswa & Guru \\
\hline 1. $\begin{array}{l}\text { Hipotesis merupakan suatu pernyataan } \\
\text { (bukan pertanyaan) yang mencerminkan }\end{array}$ & 5 & & \\
\hline 2. $\begin{array}{l}\text { Prediksi-prediksi dapat dihasilkan dari } \\
\text { hipotesis tersebut }\end{array}$ & 5 & & \\
\hline 3. $\begin{array}{l}\text { Diberikan suatu pembenaran yang penuh } \\
\text { pemikiran mengapa dirumuskan hipotesis itu } \\
\text { dan prediksi-predikasi lebih spesifik dapat } \\
\text { difungsikan sebagai dasar suatu percobaan }\end{array}$ & 5 & & \\
\hline 4. $\begin{array}{l}\text { Prediksi-prediksi tersebut berguna dalam } \\
\text { merancang percobaan }\end{array}$ & 5 & & \\
\hline \multicolumn{1}{|c|}{ Total skor } & 20 & & \\
\hline
\end{tabular}

Keterangan : 5 = Amat Baik; $4=$ Baik ; $3=$ Cukup ; $2=$ Jelek ; $1=$ Amat Jelek 


\section{RUBRIK}

\section{Merumuskan Hipotesis}

\begin{tabular}{|c|l|}
\hline 5 & $\begin{array}{l}\text { Siswa membuat suatu hipotesis yang luar biasa bermakna. Prediksi-prediksi jelas dapat } \\
\text { diuji, dan siswa memberikan penjelasan-penjelasan penuh pemikiran tentang } \\
\text { bagaimana hipotesis ini dan prediksi-prediksi akan dibuat untuk dasar suatu percobaan } \\
\text { yang amat baik. }\end{array}$ \\
\hline 4 & $\begin{array}{l}\text { Siswa merumuskan suatu pernyataan hipotesis deklaratif jelas yang diikuti oleh suatu } \\
\text { prediksi yang menghubungkan variable manipulasi dengan variable respon. Tampak } \\
\text { jelas bagaimana hipotesis dan ramalan tersebut mengalir dari pengamatan-pengamatan } \\
\text { tersebut. Siswa melakukan pembenaran dengan penuh pemikiran tentang bagaimana } \\
\text { hipotesis dan prediksi tersebut akan menjadi suatu dasar yang baik untuk merancang } \\
\text { suatu percobaan. }\end{array}$ \\
\hline 3 & $\begin{array}{l}\text { Pekerjaan siswa sepertinya dapat di beri nilai 4, kecuali ada suatu unsur penting yang } \\
\text { kurang baik mengerjakannya. }\end{array}$ \\
\hline 2 & $\begin{array}{l}\text { Baik hipotesis maupun prediksi-prediksi tersebut tidak jelas. Tidak jelas bagaimana } \\
\text { hipotesis dan ramalan tersebut akan menjadi dasar suatu percobaan. }\end{array}$ \\
\hline 1 & Pekerjaan yang dilakukan amat jelek atau tidak lengkap \\
\hline
\end{tabular}


3. Menentukan variabel Penelitian (Kriteria Proses 03)

\begin{tabular}{|c|c|c|c|}
\hline \multirow{3}{*}{ Aspek yang dinilai } & \multicolumn{3}{|c|}{ Skor penilaian } \\
\hline & \multirow[t]{2}{*}{$\begin{array}{l}\text { Skor } \\
\text { Maks }\end{array}$} & \multicolumn{2}{|c|}{$\begin{array}{l}\text { Skor yang } \\
\text { diberikan }\end{array}$} \\
\hline & & Siswa & Guru \\
\hline $\begin{array}{l}\text { 1. Rancangan percobaan yang dibuat dapat } \\
\text { mengukur variabel dengan tepat }\end{array}$ & 5 & & \\
\hline $\begin{array}{l}\text { 2. Metode dan prosedur yang digunakan dalam } \\
\text { pengamatan mengikuti aturan tertentu dan } \\
\text { cukup jelas sehingga orang lain dapat } \\
\text { melaksanakannya }\end{array}$ & 5 & & \\
\hline $\begin{array}{l}\text { 3. Kosa kata, bahasa dan kalimat lengkap } \\
\text { digunakan }\end{array}$ & 5 & & \\
\hline Total skor & 15 & & \\
\hline
\end{tabular}


Rubrik

Merancang Percobaan

\begin{tabular}{|c|l|}
\hline 5 & $\begin{array}{l}\text { Rancangan percobaan jelas dapat mengukur variable yang diperlukan meliputi } \\
\text { penentuan variabel manipulasi, variable respon dan variabel kontrol serta } \\
\text { dilengkapi dengan devinisinya. Siswa menunjukkan pemahaman yang sangat jelas } \\
\text { mengenai strategi untuk melakukan rancanganya. }\end{array}$ \\
\hline 4 & $\begin{array}{l}\text { Rancangan percobaan jelas dapat mengukur variabel yang diperlukan meliputi } \\
\text { penentuan variabel manipulasi, variable respon dan variabel kontrol serta } \\
\text { dilengkapi dengan devinisinya. Siswa menunjukkan pemahaman yang cukup jelas }\end{array}$ \\
\hline 3 & $\begin{array}{l}\text { Pekerjaan siswa sepertinya dapat di beri nilai 4, kecuali ada suatu unsur penting } \\
\text { yang kurang baik mengerjakannya. }\end{array}$ \\
\hline 2 & $\begin{array}{l}\text { Rencana tidak lengkap dan atau tidak diorganisasikan dengan baik. Rencana } \\
\text { pengamatan tidak dikembangkan dengan baik. }\end{array}$ \\
\hline 1 & Pekerjaan yang dilakukan amat jelek atau tidak lengkap \\
\hline
\end{tabular}


4. Melaksanakan Penelitian

(Kriteria Proses 03a: Tape)

Petunjuk:

1. Mintalah siswa menentukan produk bioteklologi sederhana apa (tape atau nata de coco) yang akan ia demontrasikan dalam tes ini.

2. Berilah tanda cek $(\sqrt{ })$ pada tempat/kotak yang sesuai menurut apa yang telah disedikan dan dilakukan siswa anda.

3. Apabila ada yang kurang jelas, Bapak/Ibu dapat menayakan kepada siswa.

Nama:

Kelas:

No. Urut : 


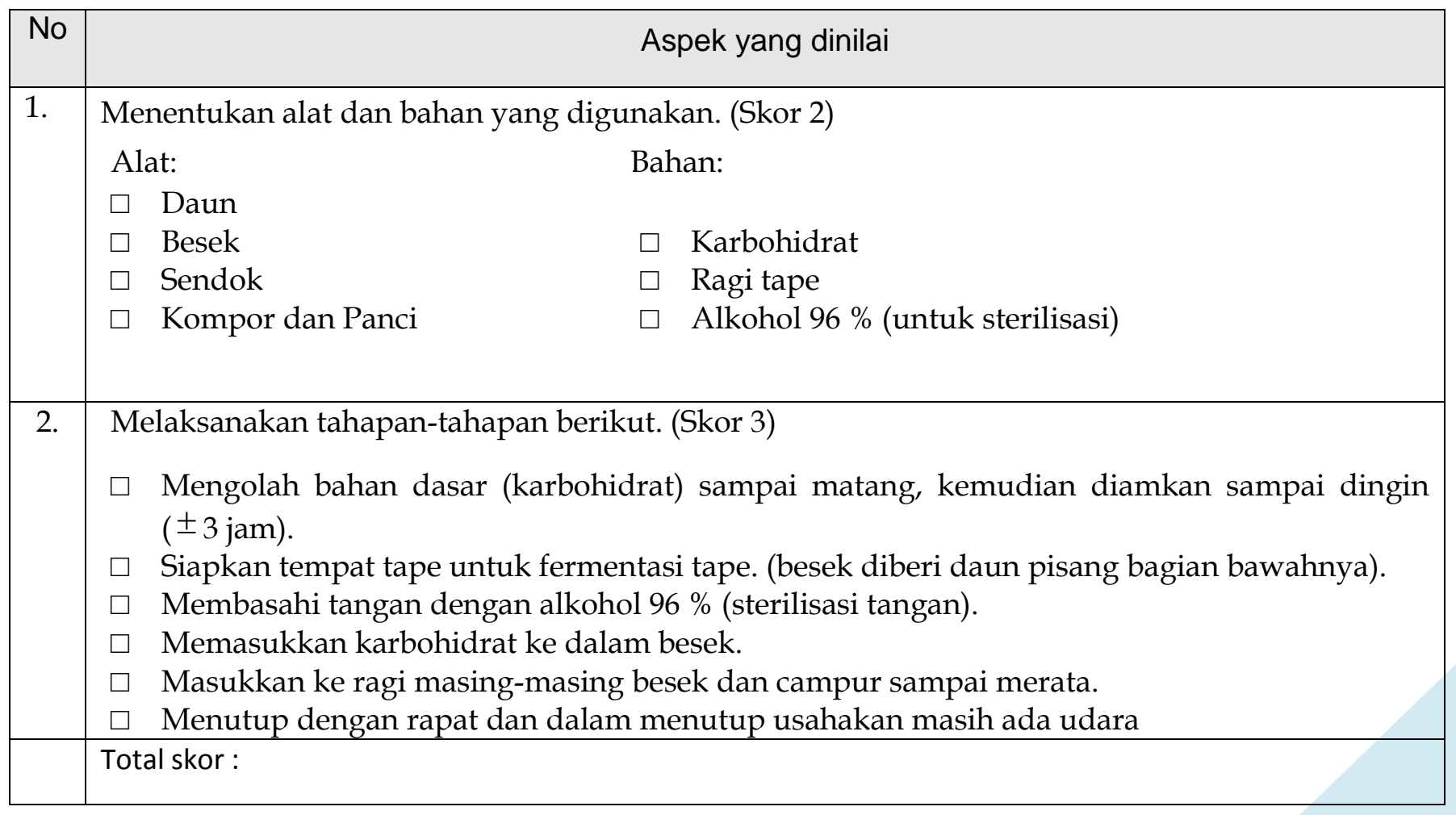




\section{Melaksanakan Penelitian}

(Kriteria Proses 03b: Nata)

\section{Petunjuk:}

1. Mintalah siswa menentukan produk bioteklologi sederhana apa (tape atau nata de coco) yang akan ia demontrasikan dalam tes ini.

2. Berilah tanda cek $(\sqrt{ })$ pada tempat/kotak yang sesuai menurut apa yang telah disedikan dan dilakukan siswa anda.

3. Apabila ada yang kurang jelas, Bapak/Ibu dapat menayakan kepada siswa

Nama:

Kelas:

No. Urut : 


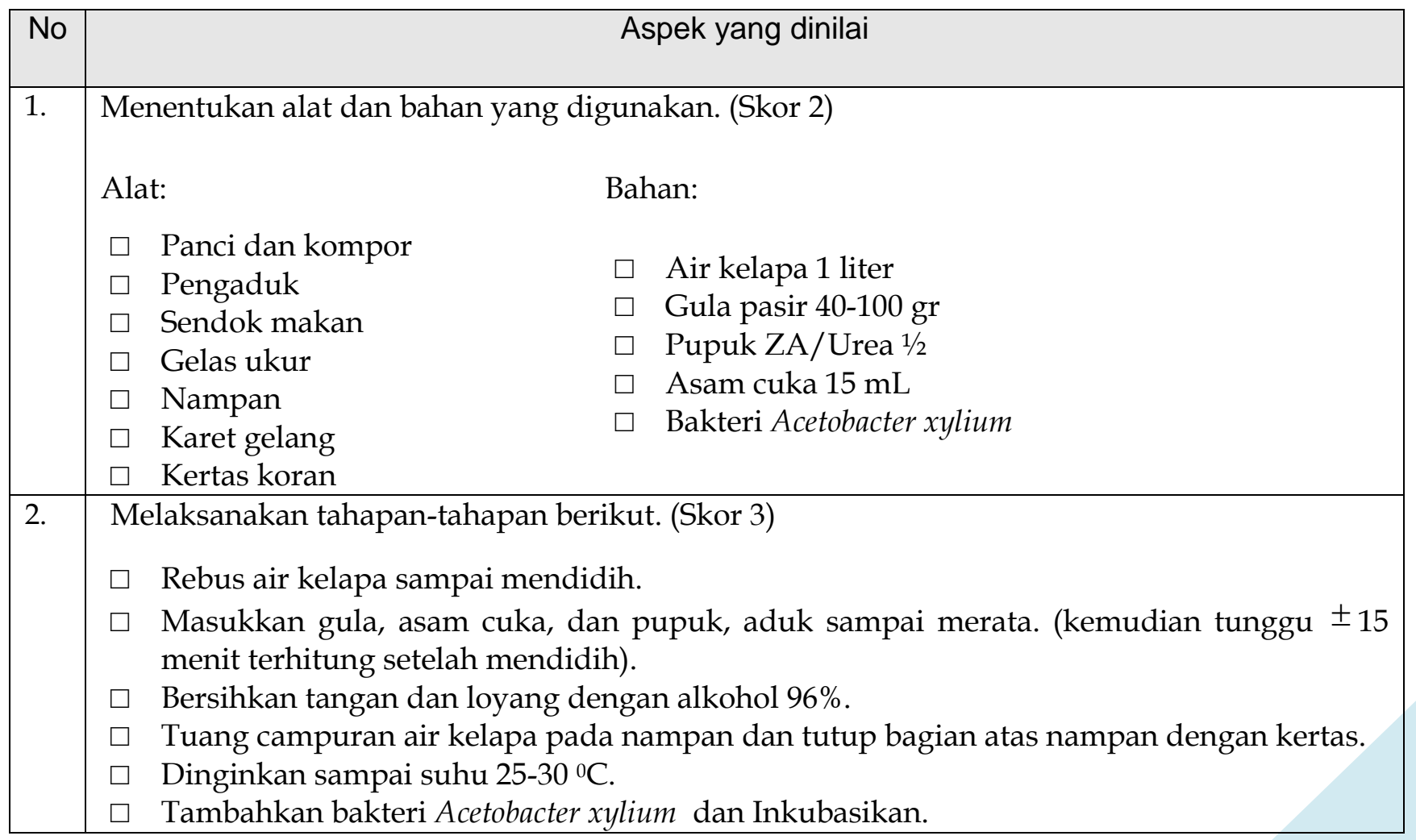


Total skor:

Surabaya,

2007

Guru Mata Pelajaran

$($ (...................................... 
5. Menuliskan Data dalam Bentuk Tabel (Kriteria Proses 04)

\begin{tabular}{|c|c|c|c|}
\hline \multirow{3}{*}{ Aspek yang dinilai } & \multicolumn{3}{|c|}{ Skor penilaian } \\
\hline & \multirow{2}{*}{$\begin{array}{l}\text { Skor } \\
\text { Maks }\end{array}$} & \multicolumn{2}{|c|}{ Skor yang diberikan } \\
\hline & & Siswa & Guru \\
\hline 1. Tabel data mengandung data yang cocok & 5 & & \\
\hline $\begin{array}{l}\text { 2. Tabel data dilengkapi dengan judul yang } \\
\text { cocok }\end{array}$ & 5 & & \\
\hline $\begin{array}{l}\text { 3. Unit pengukuran untuk semua variabel } \\
\text { ditunjukkan dengan jelas }\end{array}$ & 5 & & \\
\hline 4. Tabel data teratur dan dapat disajikan & 5 & & \\
\hline Total skor & 20 & & \\
\hline
\end{tabular}

Keterangan : 5 = Amat Baik; $4=$ Baik ; 3= Cukup ; 2 = Jelek ; 1= Amat Jelek

Rubrik

Menuliskan data dalam 


\begin{tabular}{|c|l|}
\hline 5 & $\begin{array}{l}\text { Tabel data diorganisasikan dengan baik, lengkap, dan jelas. Keakuratan data sesuai } \\
\text { dengan perkakas yang digunakan. Paparan data mengandung pengerian prosedur } \\
\text { yang panjang. Tabel disajikan dengan rapi dan teratur }\end{array}$ \\
\hline 4 & $\begin{array}{l}\text { Tabel data yang dibuat bagus (memiliki judul yang tepat). Keakuratan data yang } \\
\text { dikumpulkan dari pengukuran alat/ instrumen adalah memuaskan. Paparan data } \\
\text { mengandung pengertian umum dari prosedur yang panjang }\end{array}$ \\
\hline 3 & $\begin{array}{l}\text { Pekerjaan siswa sepertinya dapat di beri nilai 4, kecuali ada suatu unsur penting yang } \\
\text { kurang baik mengerjakannya. }\end{array}$ \\
\hline 2 & $\begin{array}{l}\text { Tabel data yang dibuat keakuratan datanya tidak sesuai dengan perkakas yang } \\
\text { digunakan. Paparan data mempunyai berbagai kendala yang berhubungan dengan } \\
\text { prosedur yang panjang. Tabel data tidak diorganisasikan dengan baik dan tidak rapi }\end{array}$ \\
\hline 1 & \begin{tabular}{l} 
Pekerjaan yang dilakukan amat jelek atau tidak lengkap \\
\hline
\end{tabular}
\end{tabular}

6. Membuat Analisis Data (Kriteria Proses 05) 


\begin{tabular}{|c|c|c|c|}
\hline \multirow{3}{*}{ Aspek yang dinilai } & \multicolumn{3}{|c|}{ Skor penilaian } \\
\hline & \multirow{2}{*}{$\begin{array}{l}\text { Skor } \\
\text { Maks }\end{array}$} & \multicolumn{2}{|c|}{$\begin{array}{l}\text { Skor yang } \\
\text { diberikan }\end{array}$} \\
\hline & & Siswa & Guru \\
\hline 1. Analisis dilakukan untuk seluruh data. & 5 & & \\
\hline $\begin{array}{l}\text { 2. Analisis dilakukan menggunakan prosedur } \\
\text { statistik yang cocok. }\end{array}$ & 5 & & \\
\hline 3. Analisis yang dilakukan akurat dan seksama. & 5 & & \\
\hline Total skor & 15 & & \\
\hline
\end{tabular}

Keterangan : 5 = Amat Baik; $4=$ Baik ; $3=$ Cukup ; 2 = Jelek ; $1=$ Amat Jelas 


\section{RUBRIKS}

Analisis Data

\begin{tabular}{|c|l|}
\hline 5 & $\begin{array}{l}\text { Siswa membuat analisis dengan sangat cermat dan menunjukkan } \\
\text { pemahaman yang tinggi. Matematika digunakan secara benar. }\end{array}$ \\
\hline 4 & $\begin{array}{l}\text { Siswa menggunakan semua data dalam analisis dan menggunakan } \\
\text { prosedur matematika secara benar untuk menganalisis data. }\end{array}$ \\
\hline 3 & $\begin{array}{l}\text { Pekerjaan siswa sepertinya dapat di beri nilai 4, kecuali ada suatu } \\
\text { unsur penting yang kurang baik mengerjakannya. }\end{array}$ \\
\hline 2 & $\begin{array}{l}\text { Analisis tidak menggunakan semua data yang ada. Prosedur statistik } \\
\text { yang digunakan tidak cocok/ tidak akurat penerapannya. }\end{array}$ \\
\hline 1 & Pekerjaan yang dilakukan amat jelek atau tidak lengkap. \\
\hline
\end{tabular}


7. Membuat Kesimpulan (Kriteria Proses 06)

\begin{tabular}{|c|c|c|c|}
\hline \multirow{3}{*}{ Aspek yang dinilai } & \multicolumn{3}{|c|}{ Skor penilaian } \\
\hline & \multirow{2}{*}{$\begin{array}{l}\text { Skor } \\
\text { Maks }\end{array}$} & \multicolumn{2}{|c|}{$\begin{array}{l}\text { Skor yang } \\
\text { diberikan }\end{array}$} \\
\hline & & Siswa & Guru \\
\hline $\begin{array}{l}\text { 1. Kesimpulan yang diambil berdasarkan data } \\
\text { yang diperoleh dan bukan pendapat pribadi. }\end{array}$ & 5 & & \\
\hline $\begin{array}{l}\text { 2. Kesimpulan yang diambil singkat, jelas, dan } \\
\text { lengkap. }\end{array}$ & 5 & & \\
\hline $\begin{array}{l}\text { 3. Kesimpulan sesuai dengan kegiatan yang } \\
\text { dilakukan. }\end{array}$ & 5 & & \\
\hline Total skor & 15 & & \\
\hline
\end{tabular}

Keterangan : 5 = Amat Baik; $4=$ Baik ; $3=$ Cukup ; 2 = Jelek ; $1=$ Amat Jelek. 


\section{RUBRIKS}

Membuat Kesimpulan

\begin{tabular}{|c|l|}
\hline 5 & $\begin{array}{l}\text { Siswa membuatkesimpulan dengan sangat cermat dan menunjukkan pemahaman } \\
\text { yang tinggi yang digunakan secara benar. }\end{array}$ \\
\hline 4 & $\begin{array}{l}\text { Siswa menggunakan semua data dalam analisis dan menggunakan prosedur secara } \\
\text { benar untuk menganalisis data. }\end{array}$ \\
\hline 3 & $\begin{array}{l}\text { Pekerjaan siswa sepertinya dapat di beri nilai 4, kecuali ada suatu unsur penting yang } \\
\text { kurang baik mengerjakannya. }\end{array}$ \\
\hline 2 & $\begin{array}{l}\text { Analisis tidak menggunakan semua data yang ada. Prosedur statistik yang digunakan } \\
\text { tidak cocok/ tidak akurat penerapannya. }\end{array}$ \\
\hline 1 & Pekerjaan yang dilakukan amat jelek atau tidak lengkap. \\
\hline
\end{tabular}




\section{DAFTAR PUSTAKA}

Hibbard, K. Michael. 1997. Performance Assessment in The Science Classroom. New York: McGraw-Hill.

Ibrahim, Muslimin. 2005. Asesmen Berkelanjutan: Konsep Dasas, Tahapan Pengembangan dan Contoh. Surabaya: Unesa University Press. 


\section{BIODATA PENULIS}

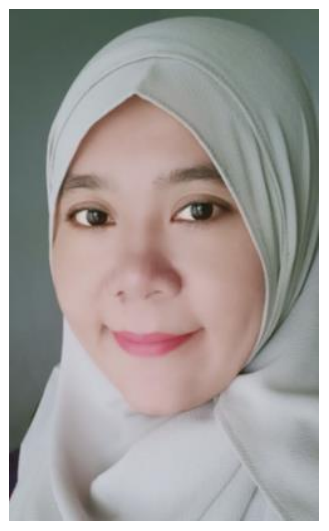

Fitria Eka Wulandari, lahir di Bondowoso 12 Juli 1983. Pendidikan dasar ditempuhnya di sekolah dasar Negeri Mangli Wetan 1 di daerah kelahirannya. Pendidikan menengah Pertama ditempuhnya di SMP Negeri 1 Tapen. Pendidikan Menengan Atas ditempuhnya di SMU Negeri 1 Renggarang. Pendidikan S1 diselesaikan di Universitas Negeri Surabaya pada tahun 2006. Gelar Magister Pendidikan bidang sains diperolehnya dari Universitas Negeri Surabaya padatahun 2010. Sejak tahun 2010 sampai sekarang, menjadi dosen tetap di prodi Pendidikan IPA Universitas Muhammadiyah Sidoarjo.

Ria Wulandari, lahir di Kediri, 16 April 1985. Pendidikan dasar ditempuhnya di sekolah dasar negeri di daerah kelahirannya. Pendidikan menengah ditempuhnya di SMA Negeri 1 Kediri. Pendidikan S1 diselesaikan di Universitas Negeri Malang pada tahun 2007. Gelar Magister Pendidikan bidang sains diperolehnya dari Universitas Negeri Surabaya padatahun 2010. Pada tahun

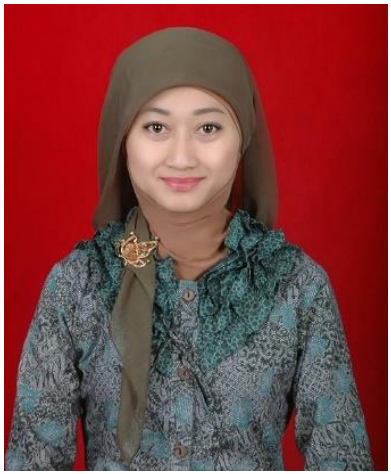
2016 mendapatkan beasiswa BUDI-DN untuk melanjutkan studi S3 di Universitas Negeri Yogyakarta. Sejak tahun 2013 sampai sekarang, menjadi dosen tetap di prodi Pendidikan IPA Universitas Muhammadiyah Sidoarjo. 